\title{
The EPSA Project Finance Mapping Tool
}

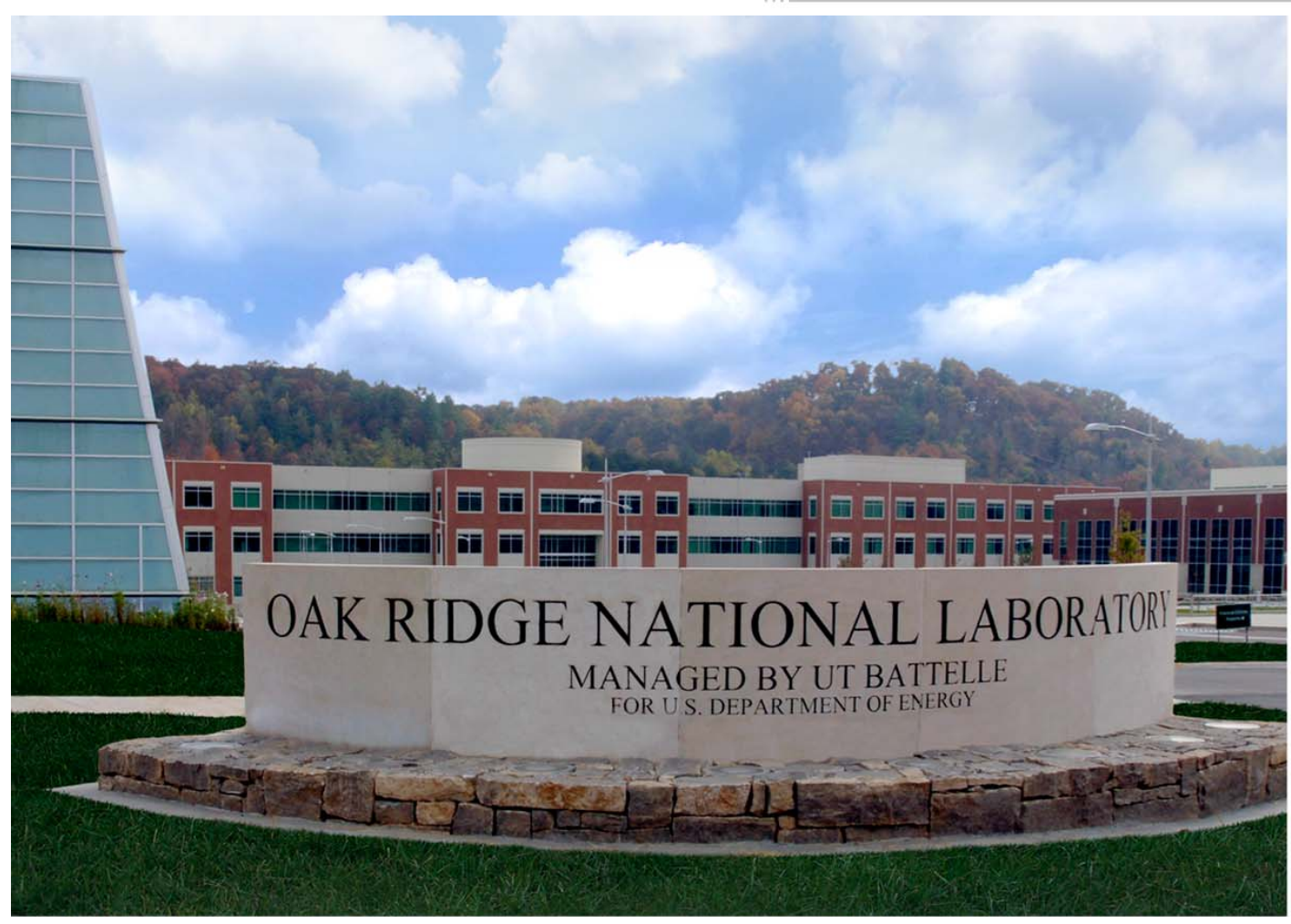

Approved for public release. Distribution is unlimited.
Stanton W. Hadley

Supriya Chinthavali

July 2016 


\section{DOCUMENT AVAILABILITY}

Reports produced after January 1, 1996, are generally available free via US Department of Energy (DOE) SciTech Connect.

Website http://www.osti.gov/scitech/

Reports produced before January 1, 1996, may be purchased by members of the public from the following source:

National Technical Information Service

5285 Port Royal Road

Springfield, VA 22161

Telephone 703-605-6000 (1-800-553-6847)

TDD 703-487-4639

Fax 703-605-6900

E-mail info@ntis.gov

Website http://www.ntis.gov/help/ordermethods.aspx

Reports are available to DOE employees, DOE contractors, Energy Technology Data Exchange representatives, and International Nuclear Information System representatives from the following source:

Office of Scientific and Technical Information

PO Box 62

Oak Ridge, TN 37831

Telephone 865-576-8401

Fax 865-576-5728

E-mail reports@osti.gov

Website http://www.osti.gov/contact.html

This report was prepared as an account of work sponsored by an agency of the United States Government. Neither the United States Government nor any agency thereof, nor any of their employees, makes any warranty, express or implied, or assumes any legal liability or responsibility for the accuracy, completeness, or usefulness of any information, apparatus, product, or process disclosed, or represents that its use would not infringe privately owned rights. Reference herein to any specific commercial product, process, or service by trade name, trademark, manufacturer, or otherwise, does not necessarily constitute or imply its endorsement, recommendation, or favoring by the United States Government or any agency thereof. The views and opinions of authors expressed herein do not necessarily state or reflect those of the United States Government or any agency thereof. 
Electrical \& Electronics Systems Research Division

Computational Sciences \& Engineering Division

\section{THE EPSA PROJECT FINANCE MAPPING TOOL}

Stanton W. Hadley

Supriya Chinthavali

Date Published: July 2016

Prepared by

OAK RIDGE NATIONAL LABORATORY

Oak Ridge, Tennessee 37831-6283

managed by

UT-BATTELLE, LLC

for the

US DEPARTMENT OF ENERGY

under contract DE-AC05-00OR22725 



\section{CONTENTS}

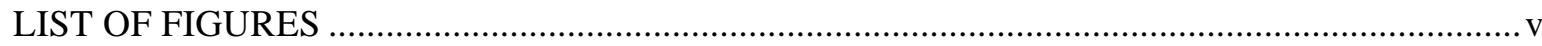

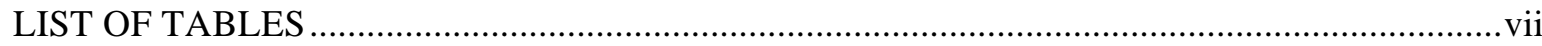

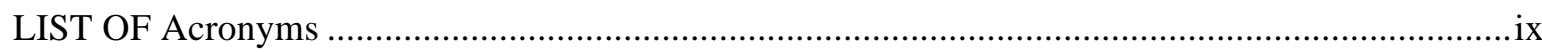

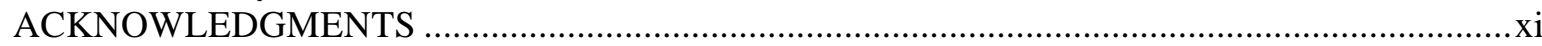

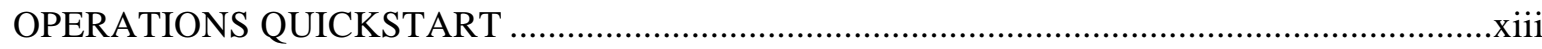

ABSTRACT

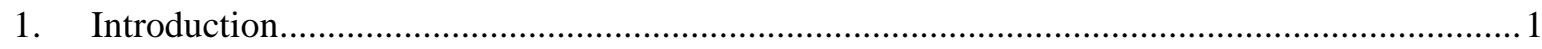

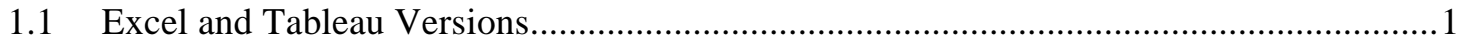

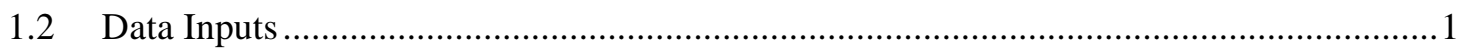

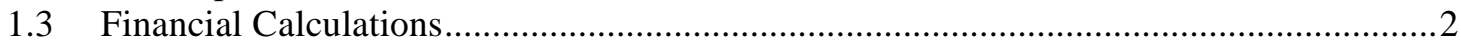

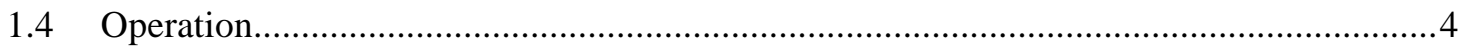

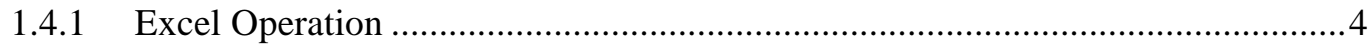

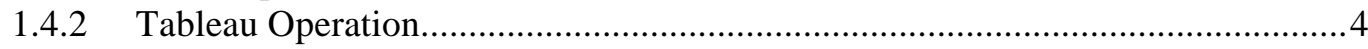

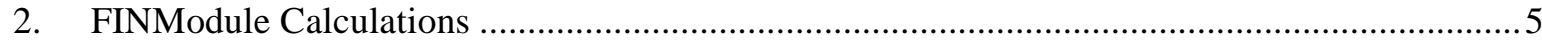

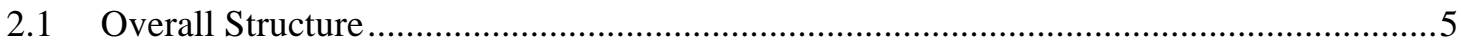

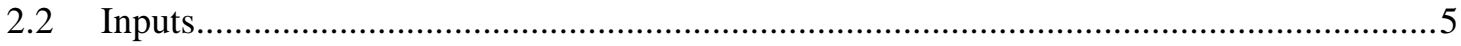

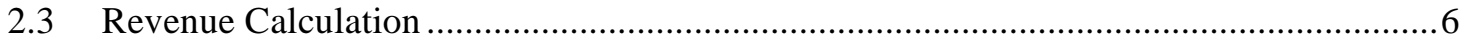

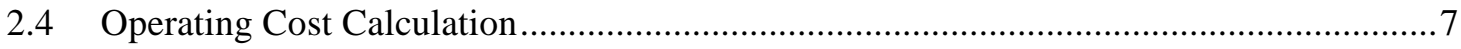

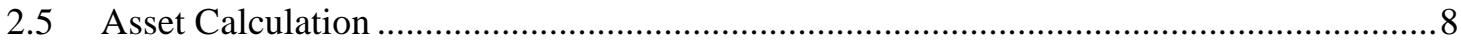

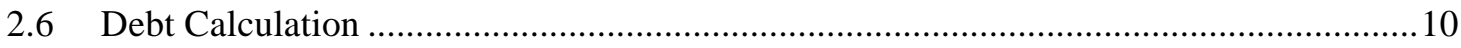

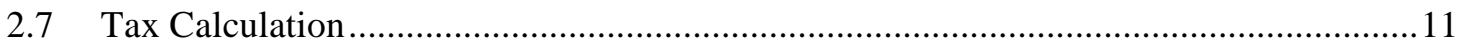

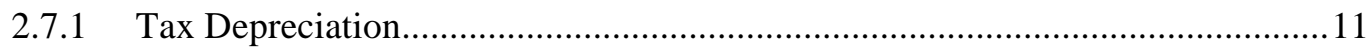

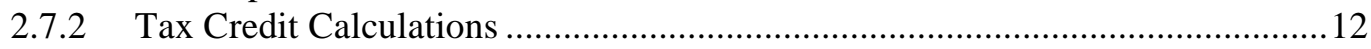

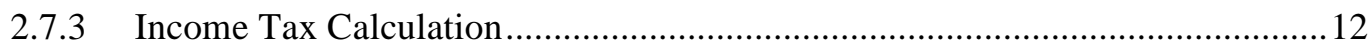

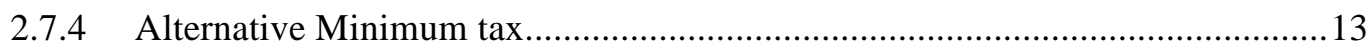

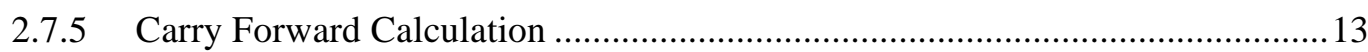

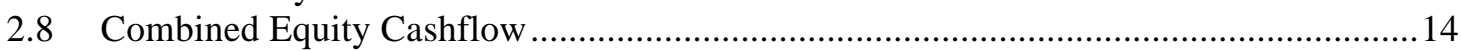

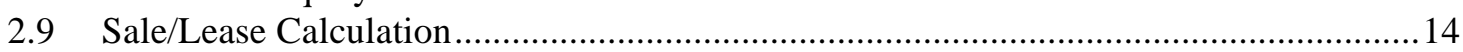

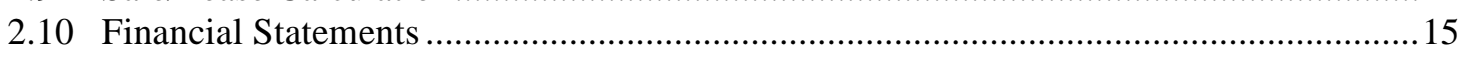

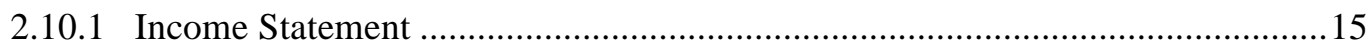

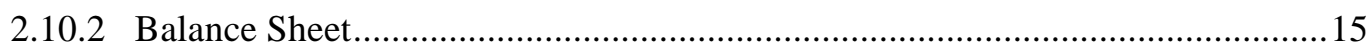

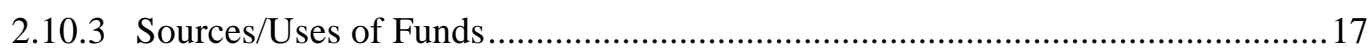

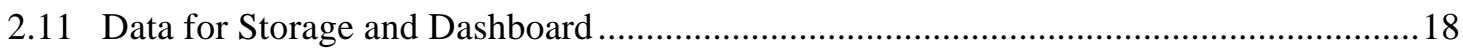

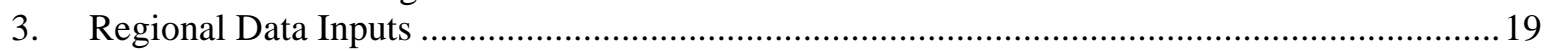

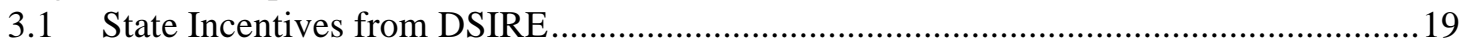

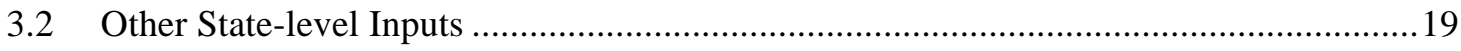

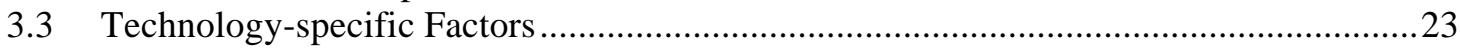

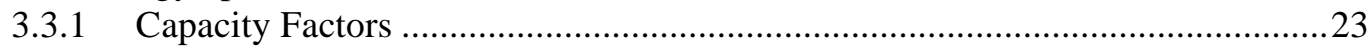

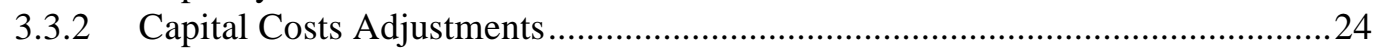

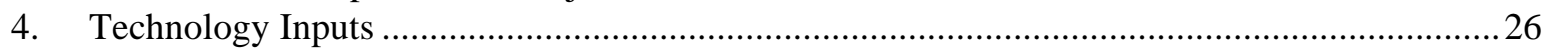

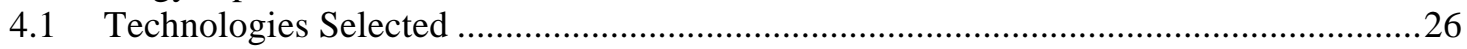

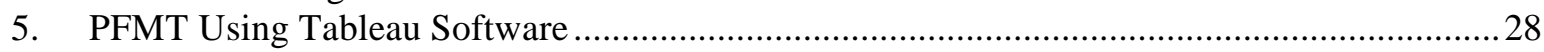

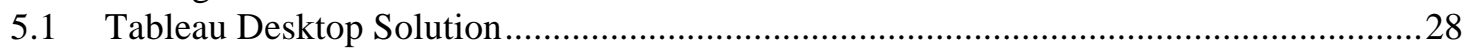

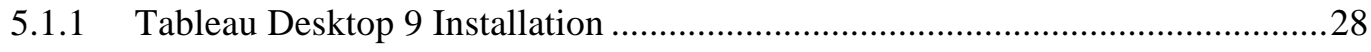

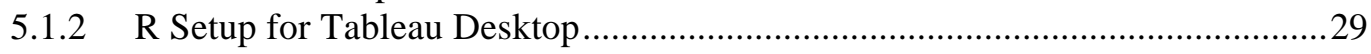

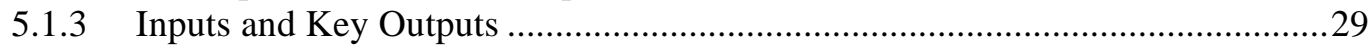




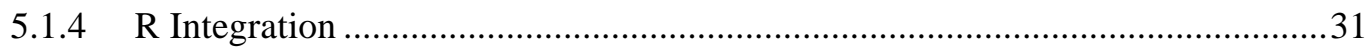

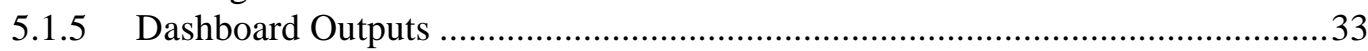

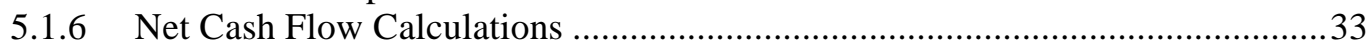

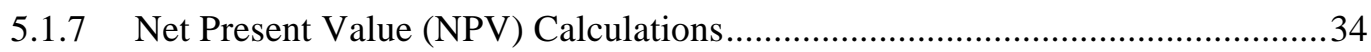

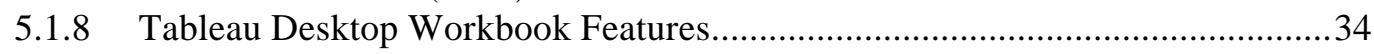

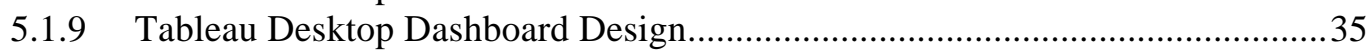

5.1.10 Tableau Dashboards Created Within Tableau Desktop ...........................................

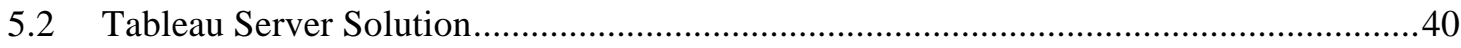

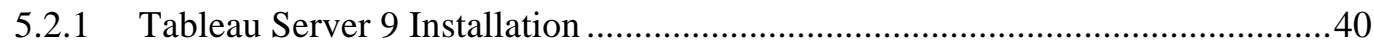

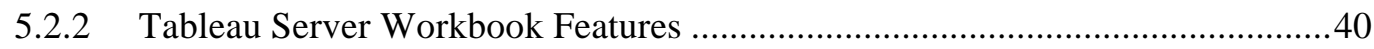

5.2.3 Tableau Server Workbook Scenario Details.......................................................

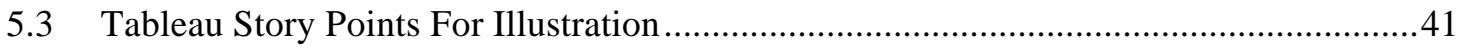

5.3.1 Tableau Dashboards Published On Tableau Server.............................................43

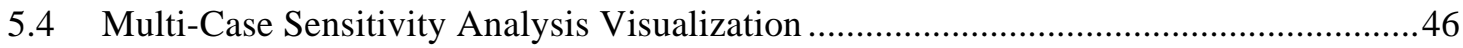

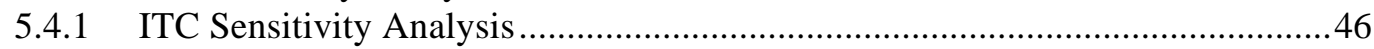

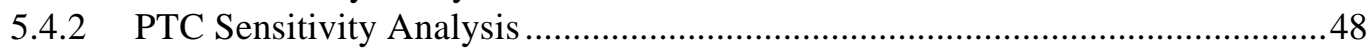

5.4.3 Accelerated Depreciation Sensitivity Analysis...............................................49

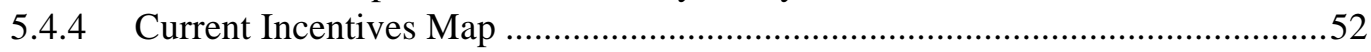

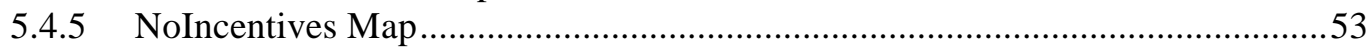

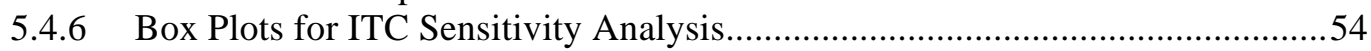

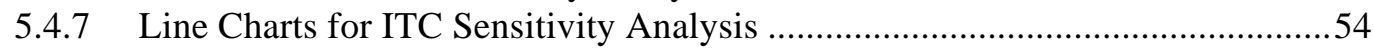

5.4.8 NPV Charts for ITC Sensitivity Analysis ........................................................56

5.4.9 Net Cash Flow Charts for ITC Sensitivity Analysis..........................................57

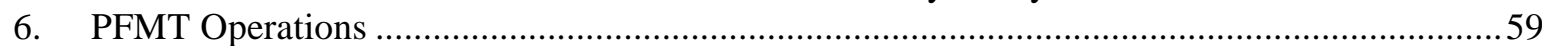

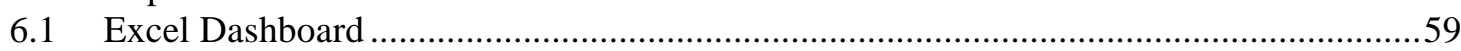

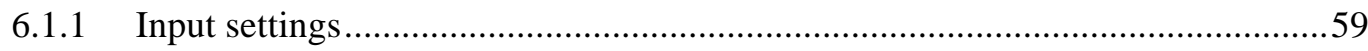

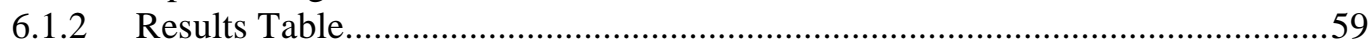

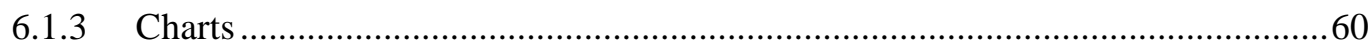

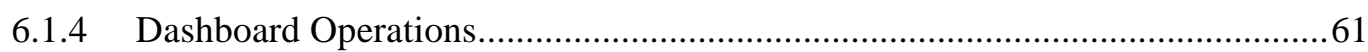

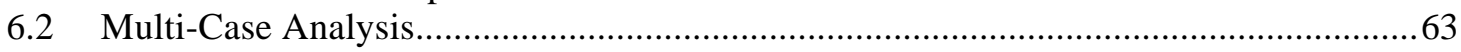

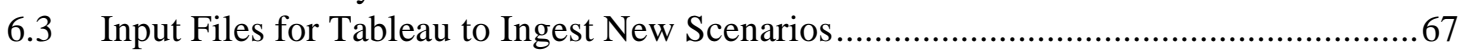

6.4 TABLEAU VISUALIZATION OF EXISTING SCENARIOS WITHIN LEP AND NET

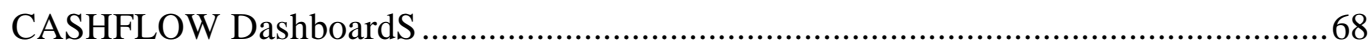

6.4.1 Input settings for existing scenarios within PPA and NetCashFlow

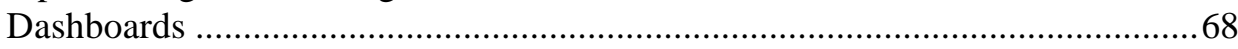

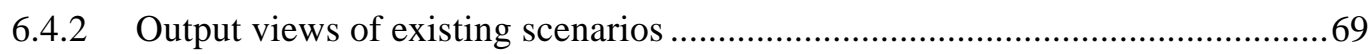

6.5 Tableau Visualization of New Scenarios within Sensitivity Analysis Dashboards.........71

6.6 Tableau Visualization of Existing Scenarios within Sensitivity Analysis Dashboards ...72

6.7 Tableau Visualization of New Scenarios within LEP Dashboard and Net Cash Flow

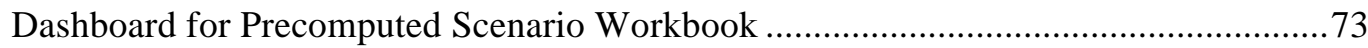

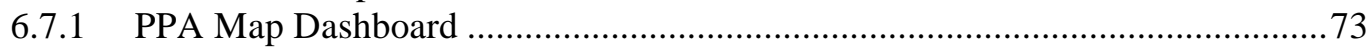

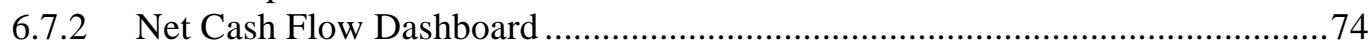

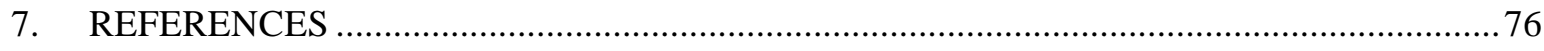




\section{LIST OF FIGURES}

Figure

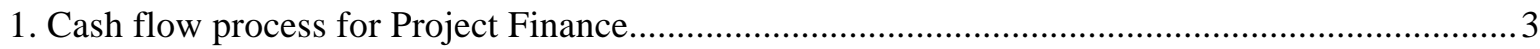

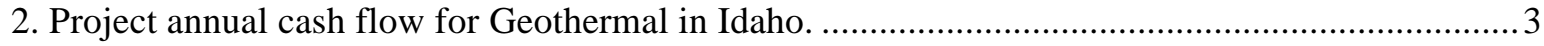

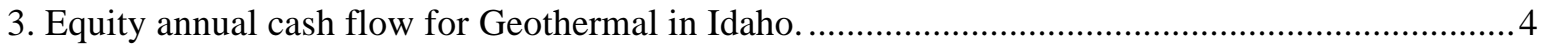

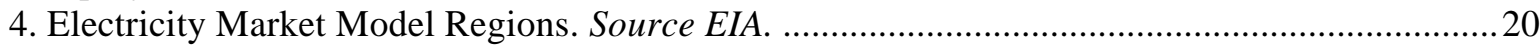

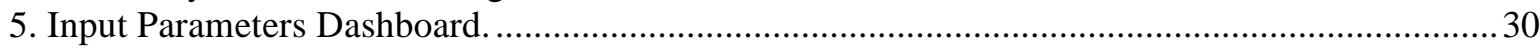

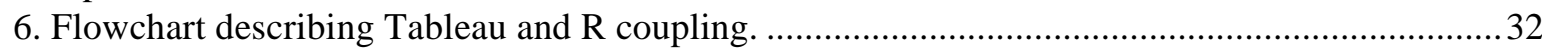

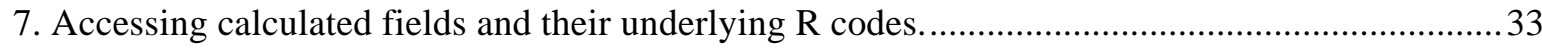

8. LEP Map Dashboard for 150 MW PV Technology with Tableau Desktop. ................................36

9. Net Cash Flow Dashboard for 7 MW PV Technology within Tableau Desktop...........................37

10. LEP Map Dashboard for 7 MW PV Technology within Tableau Desktop. ................................38

11. National Summary Dashboard for Geothermal Technology within Tableau Desktop................ 39

12. StateData-DSIRE+ LEP Map Dashboard within Tableau Desktop...........................................40

13. Story Points Describing Sensitivity to PTC Changes for Onshore Wind Technology................42

14. Story Points Describing Sensitivity to ITC Changes for Large PV Technology........................43

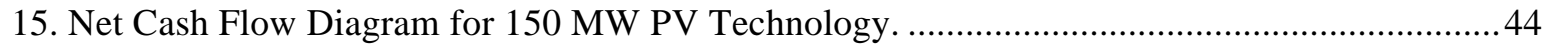

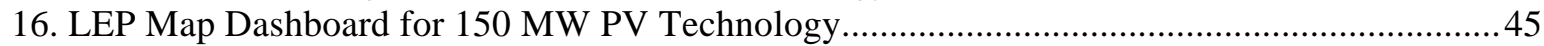

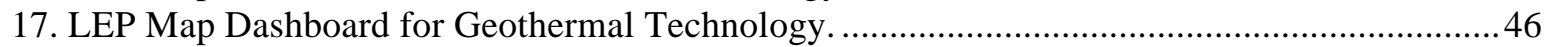

18. Tiled maps of LEP-System prices for LargePV,Onshore Wind,Gas CC and Geothermal

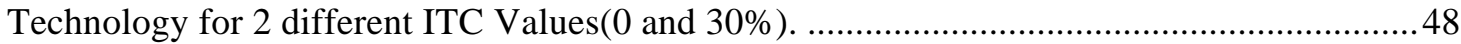

19. Tiled maps of LEP-System prices for Large PV, Onshore Wind, Gas CC, and Geothermal

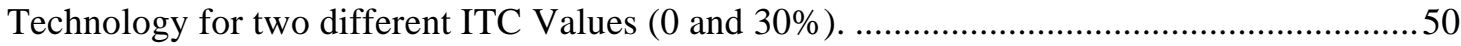

20. Figure shows eight tiled maps of LEP-System prices for Large PV, Onshore Wind, Gas CT, and

Geothermal Technology for two different TaxDepLife Values (5 and 30 years). ....................51

21. Eight tiled maps of LEP-System prices for Large PV, Onshore Wind, Gas CT, and Geothermal

Technology with current valid incentives for ITC and PTC. ............................................52

22. Eight tiled maps of LEP-System prices for Large PV, Onshore Wind, Gas CT, and Geothermal

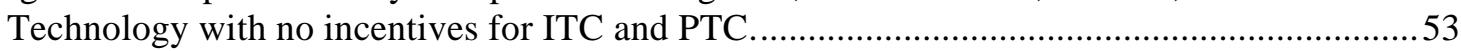

23. Box plots of LEP prices for Large PV and Small PV Technology for various values of ITC. ...54

24. Line of LEP prices and system prices for Large and Small PV Technology for various values of

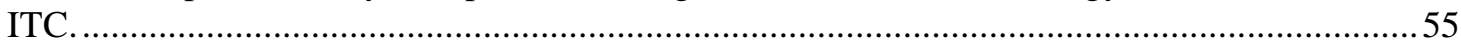

25. ROE prices and ROE D+E prices for Large and Small PV Tech for various ITC values...........56

26. NPV Dashboard for Large PV Technology displaying values for different ITC inputs............57

27. NetCashFlow Dashboard for Large PV Technology displaying values for different ITC

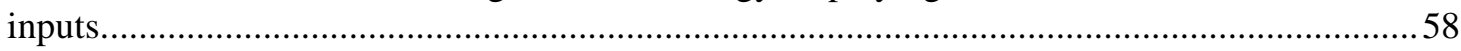

28. Example map and other charts from Dashboard for Large PV ...........................................61

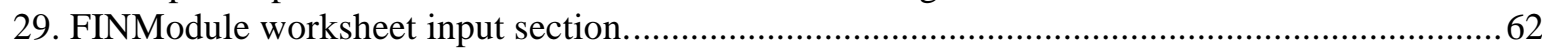

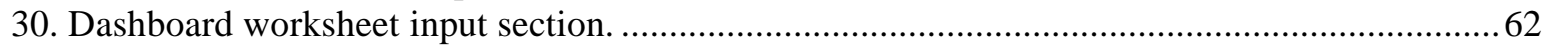

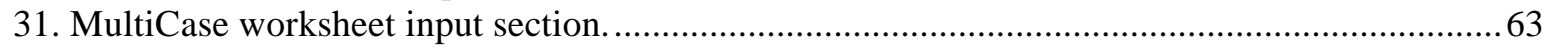

32. Comparison of ITC effects on levelized costs for four technologies in Oklahoma.....................64

33. Comparison of ITC effects on levelized costs for four technologies in Oklahoma.....................65

34. Tax depreciation effects on levelized prices for eight technologies in California.......................67

35. Tax depreciation effects on levelized costs for eight technologies in California.......................67

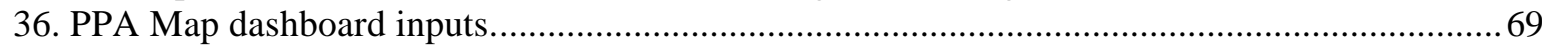

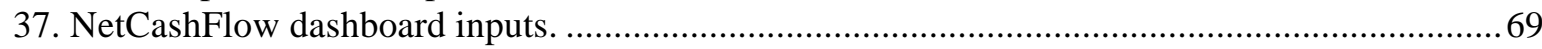

38. PPA Map dashboard displaying the LEP prices for Offshore Wind Technology. ..................... 70

39. Net Cash Flow dashboard for Offshore Wind Technology..................................................... 71 


\section{LIST OF TABLES}

Table

Page

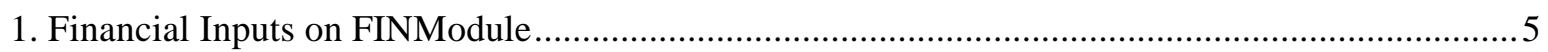

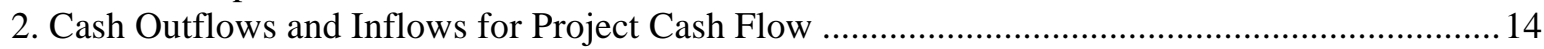

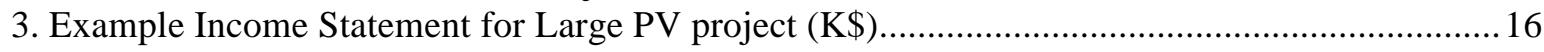

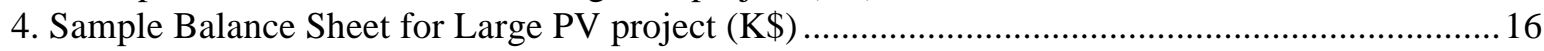

5. Sample Sources and Uses of Funds Statement for Large PV ................................................ 17

6. Balancing Authority Average System Lambda for 2014 and Applicable Region........................21

7. Matrix of calculated proportions of regional sales in each state................................................22

8. Potential Onshore Wind Resource and Capacity Factor for New York. Source: NREL ..............23

9. Capital Cost Location Percent Variation (EIA 2010) .................................................................25

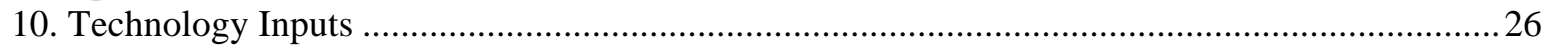

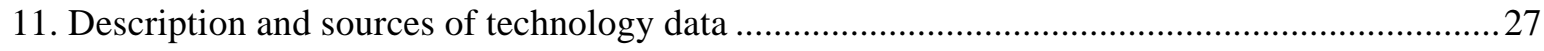

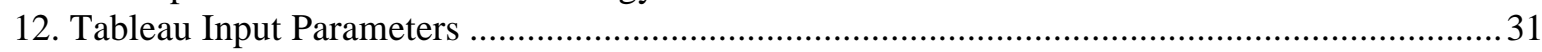

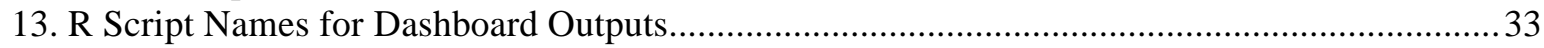

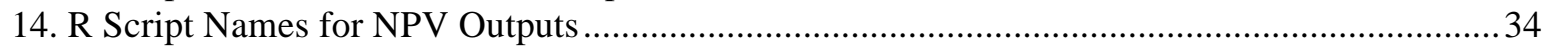

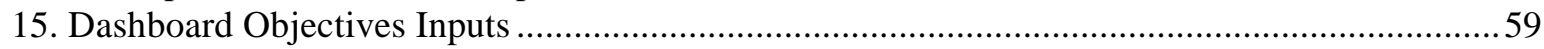

16. Results using desired return on debt + equity @ 9\% for Large PV in New York ......................60

17. Results by group using desired return on debt + equity @ 9\% for Large PV in New York ....... 60 


\section{LIST OF ACRONYMS}

\begin{tabular}{|c|c|}
\hline AEO & Annual Energy Outlook \\
\hline AFUDC & Allowance for Funds Used During Construction \\
\hline AMT & Alternative Minimum Tax \\
\hline $\mathrm{CF}$ & Capacity Factor \\
\hline CWIP & Construction Work in Progress \\
\hline DOE & U.S. Department of Energy \\
\hline DSIRE & Database of State Incentives for Renewables \& Efficiency \\
\hline DSR & Debt Service Reserves \\
\hline EIA & Energy Information Administration \\
\hline EIPC & Eastern Interconnection Planning Collaborative \\
\hline EPSA & Office of Energy Policy and Systems Analysis \\
\hline FERC & Federal Energy Regulatory Commission \\
\hline IRS & U.S. Internal Revenue Service \\
\hline ISO & Independent System Operator \\
\hline ITC & Investment Tax Credit \\
\hline LEP & Levelized Energy Price \\
\hline LEPR & Levelized Energy Price + REC Price \\
\hline MACRS & Modified Accelerated Cost Recovery System \\
\hline MWh & megawatt per hour \\
\hline NEMS & National Energy Modeling System \\
\hline NPV & Net Present Value \\
\hline NREL & National Renewable Energy Laboratory \\
\hline O\&M & Operating and Maintenance \\
\hline P\&E & Plant and Equipment \\
\hline PFMT & Project Finance Mapping Tool \\
\hline PTC & Production Tax Credit \\
\hline PV & Photovoltaic \\
\hline REC & Renewable Energy Credit \\
\hline $\mathrm{ROD}+\mathrm{E}$ & Return on Debt and Equity \\
\hline ROE & Return on Equity \\
\hline RTO & Regional Transmission Operator \\
\hline WACC & Weighted Average Cost of Capital \\
\hline WC & Working Capital \\
\hline
\end{tabular}




\section{ACKNOWLEDGMENTS}

We would like to thank Malikarjun Shankar, Olefemi Omitaomu, Sreenivas Sukumar, and Linda Sylvester. Their guidance, suggestions, and support helped in defining the project and providing data for the work. We would especially like to thank the sponsors of this work, Eric Hsieh, Stephen Hendrickson, and Rebecca Dell of the DOE Office of Energy Policy and Systems Analysis. Their support, suggestions, and assistance have been invaluable to the development of this project. 


\section{OPERATIONS QUICKSTART}

Below are initial steps to open and run the Excel and server version of the Project Finance Mapping Tool (PFMT). Additional details on operations including more complex activities are covered in Section 6.

\section{To run the Excel version of PFMT for a single parameter:}

1. Open the PFMT Excel workbook. The version described here Is PFMTV4d.xlsm (or ...xlsb)

2. Make changes to desired inputs (brown cells only) on the FINModule, TechnologyInputs, StateInputs, and/or Dashboard worksheets.

3. Go to the Dashboard and click on the Green button. The model will quickly ( $\sim 5$ seconds) calculate the new results for all states and update the map to show the results.

4. The cash flow chart will show the project's inflow and outflow for the state specified in cell B5. Type a new state (or select from the dropdown list) to see a different state.

5. The FINModule will give financial details for the state specified in Dashboard!B5.

6. The map's data presented can be changed in cell K5, followed by tapping the ReColor Map button.

To run the Excel version of PFMT for multiple values:

1. Open the PFMT Excel workbook.

2. Set the base input values desired in (brown cells only) on the FINModule, TechnologyInputs, StateInputs, and/or Dashboard worksheets.

3. On the MultiCase sheet select the variable to change, minimum value, maximum value, and number of cases in cells C3:C6.

4. Select the technologies to be graphed in cells A9:H9. If fewer than eight are desired, leave the remaining cells blank.

5. Click on the green button to run the cases for each of the technologies selected. This may take a while depending on the number of cases and technologies.

6. Select the state to be shown in the graphs in cell C12. If not all cases are showing or there is \#N/A in the graphs' $x$-axes, then click on the pink button followed by the blue button.

There is further information on operating the Excel model in Sections 6.1 through 6.3.

\section{To run the server version of Tableau:}

1. Open a browser and select the web location http://infoviz.ornl.gov:8080/\#/signin?redirect=\%2Fprojects\%2F4\%2Fworkbooks

2. Sign in with the appropriate user name and password. 
3. Open the workbook PFMT_PrecomputedDashboards.

4. Make changes to desired inputs in the left pane on the PPA Map Dashboard and Net Cash Flow Dashboard. The values available for selection are either listed in the radio buttons or in the dropdown lists for the different variables.

5. The visualizations should automatically update the map, and the cash flow chart will show the project's inflow and outflow for selected states on the map or the region filter.

Note 1: There are a number of different worksheets (dashboards, maps, input listings, plots, and linecharts). Key diagrams of interest are: PPA Map Dashboard, Net Cash Flow Dashboard, ITC-SA-D1, ITC-SA-D2, ITC-SA-D3, ITC-SA-D4, ITC-SA-D5, D6-ITCMaps, D7-PTCMaps, D8-TaxDepLifeMap,CurrentIncentives-D9,NoIncentives-D10.

Note 2: In the precomputed dashboards, the data were preset from an Excel set of scenarios. The user may select from the various parameters that were included in that set of Excel cases (for example, changes in tax credits or rates, technology, returns on equity, etc.) but not make other changes and associated calculations within the server version. 


\begin{abstract}
The Energy Policy and Systems Analysis Office of the U.S. Department of Energy has requested a tool to compare the impact of various Federal policies on the financial viability of generation resources across the country. Policy options could include production tax credits, investment tax credits, solar renewable energy credits, tax abatement, accelerated depreciation, tax-free loans, and others. The tool would model the finances of projects in all fifty states, and possibly other geographic units such as utility service territories and RTO/ISO territories. The tool would consider the facility's cost, financing, production, and revenues under different capital and market structures to determine levelized cost of energy, return on equity, and cost impacts on others (e.g., load-serving entities, society.) The tool would compare the cost and value of the facility to the local regional alternatives to determine how and where policy levers may provide sufficient incremental value to motivate investment. The results will be displayed through a purpose-built visualization that maps geographic variations and shows associated figures and tables.
\end{abstract}

\title{
1. INTRODUCTION
}

The Project Finance Mapping Tool (PFMT) has been requested from the U.S. Department of Energy's (DOE's) Office of Energy Policy and Systems Analysis (EPSA) to allow a user to quickly evaluate the financial impacts of select policy choices for new power projects in each of the fifty states. One key portion is the financial calculations that are conducted in an Excel workbook. Below is the description of the workbook and its operation.

The full model consists of technology and market input data, a financial module, case output storage, a visualization dashboard of key results, and scripts or macros for operation of multiple regions and scenarios. The initial model is written entirely in Microsoft Excel, but the final product uses the Tableau software either as a standalone application or in conjunction with Excel and possibly other software systems.

The model is based on an analysis done for the U.S. Congress as a requirement of the Energy Policy Act of 1992, Report on the Study of Tax and Rate Treatment of Renewable Energy Projects (Hadley, Hill, \& Perlack, 1993). In it, the finances of a variety of renewable and non-renewable energy technologies were modeled to determine the impact of various accounting, tax, and rate policies on the relative costs of each. For the PFMT, the model was upgraded to include more recent practices and expanded to allow the rapid analysis of projects in multiple regions.

\subsection{EXCEL AND TABLEAU VERSIONS}

The PFMT comes in two versions. The first one developed is coded in Microsoft Excel. It provides a platform for rapid development and detailed analysis of the different calculations. The second is a combination of Tableau software and the $\mathrm{R}$ statistical package. It provides graphical results for ease of understanding but does not easily show the detailed calculations involved. The models are benchmarked to each other to insure duplicate results.

\subsection{DATA INPUTS}

Input data for the process cover a span of information regarding technologies, financial parameters, and state and federal tax policies. The sources for the data will vary and are listed for those that are readily available. Some inputs have been pre-calculated from recognized data sources; the calculations will be described in this report and either contained on separate sheets within the workbook or made available in separate workbooks. 
Currently, the model conducts its calculations on a state-by-state basis. The input data for states include various tax and incentive policies, wholesale prices, and marginal mix of production. Renewable incentives are collected from the Database of State Incentives for Renewables \& Efficiency (DSIRE). Inputs that are both technology- and state-specific, such as expected capacity factors or capital cost adjustments, are also captured.

Multiple types of technologies can be entered into the tool. The current set of ten technologies includes a mix of solar, wind, other renewables; natural gas; and nuclear. Base values for each technology cover cost and production characteristics such as capital cost, construction schedule, size, operating costs, fuel costs, efficiencies, and lifetime. Tax and policy factors such as tax credits and tax lives are also included.

Financial and policy inputs include such factors as interest rates, debt rates, desired return on equity, fixed price life, and sale/leaseback configuration. While base values for these are entered, these can be adjusted to better understand their impact (as can all input values.) Further information on inputs are provided in Sections 3 and 4.

\subsection{FINANCIAL CALCULATIONS}

The finance calculations are largely based on the idea of an independent project structure. A fixed price (with possible escalation factors) is typically calculated such that the resulting lifetime return on equity equals the input desired level. Alternatively, a combined debt plus equity return can be set to represent the capital requirements of the project. Furthermore, a fixed price can be set to see the resulting financial impacts. The equity portion of investment can split between a lessor and lessee to represent a sale and leaseback of the plant at the beginning of operations.

Debt calculations have been simplified to assume that at the start of operation the ratio of debt to total assets equals an input value. Debt is then repaid in equal portions over the life of the debt, consequently lowering the ratio of debt to assets. Besides plant and equipment assets, reserve accounts are established for working capital and debt service. Taxes are calculated using accelerated depreciation schedules, with the differential accrued as deferred taxes. Financial statements for the project (income statement, balance sheet, sources and uses of funds) are calculated on an annual basis within the model.

Revenue can include energy sales and renewable energy credits. Operating costs include fixed and variable portions, and these portions can be split between labor and materials (though currently set at 50\% each).

Cash flows are calculated on an annual basis for the project and its customers, debt holders, equity holders, labor and other supplies (including construction), and state and federal government, as shown in Figure 1. Included in the project assets are the undepreciated plant and equipment plus the reserve accounts for debt and operating costs. As the plant is built, funds come in from the debt and equity holders and are used to purchase the labor and material, as well as to build up the capital accounts. Once the plant starts operating, revenue comes from sales and any tax credits, and funds go out for purchases, tax payments, debt retirement, interest on debt, and dividends. Capital accounts will also change as the debt and operating cost levels change.

Asset value will rise during construction and then slowly decline over the life of the plant, ending at zero. If the cash flow components in and out of the project are plotted over time, the sources in and out balance out each year (Figure 2). Total assets peak in 2018 at $\$ 633$ million and decline to zero by 2049. If the perspective of the equity holder is taken, then cash flow appears as in Figure 3; costs are negative during construction but profits are returned through dividends. This cash flow is what is used for determining the 
return on equity (rate of return that makes the net present value equal aero.) Alternatively, the cash flow for debt + equity (the two investor classes) is combined and used to determine the combined return.

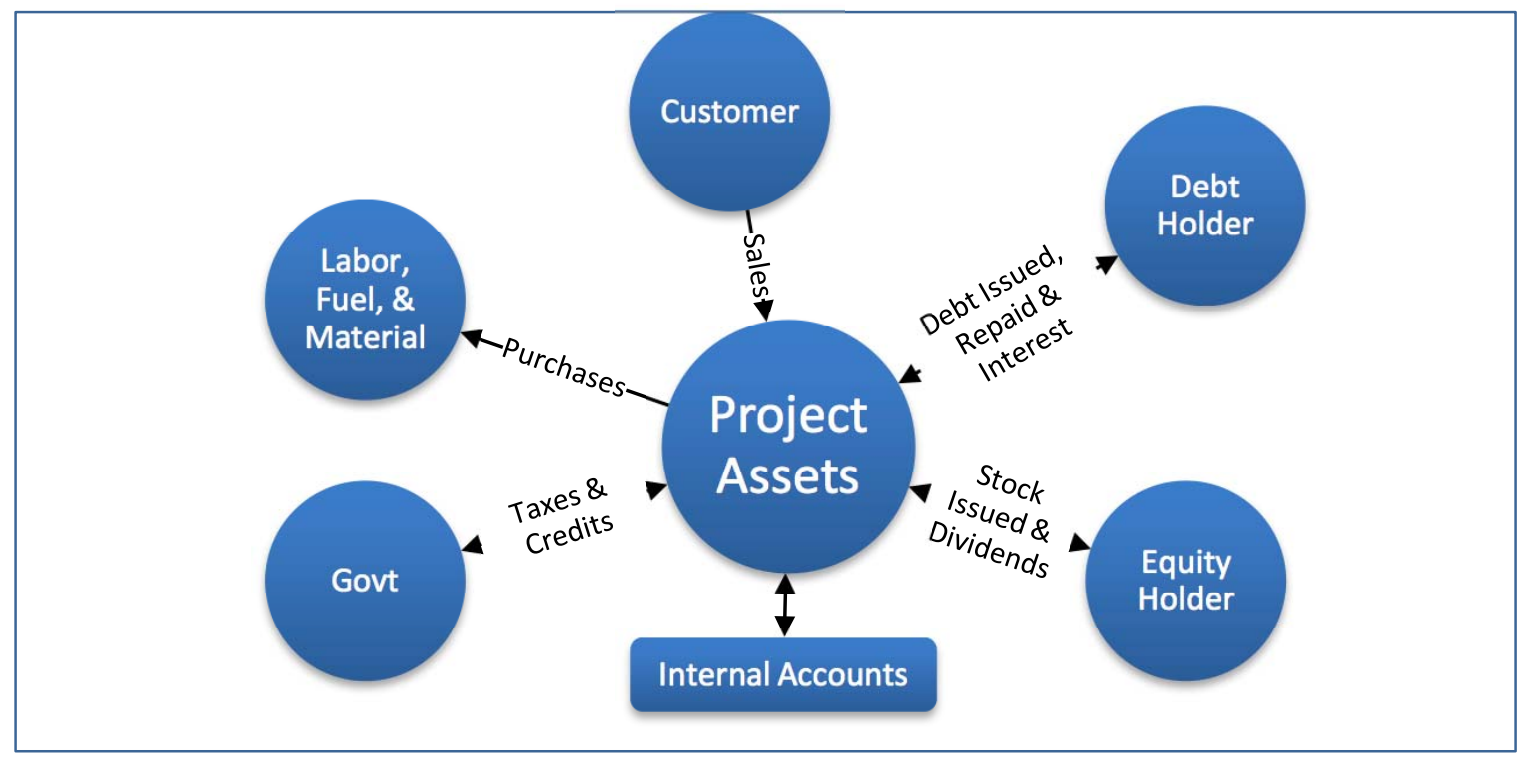

Figure 1. Cash flow process for Project Finance.

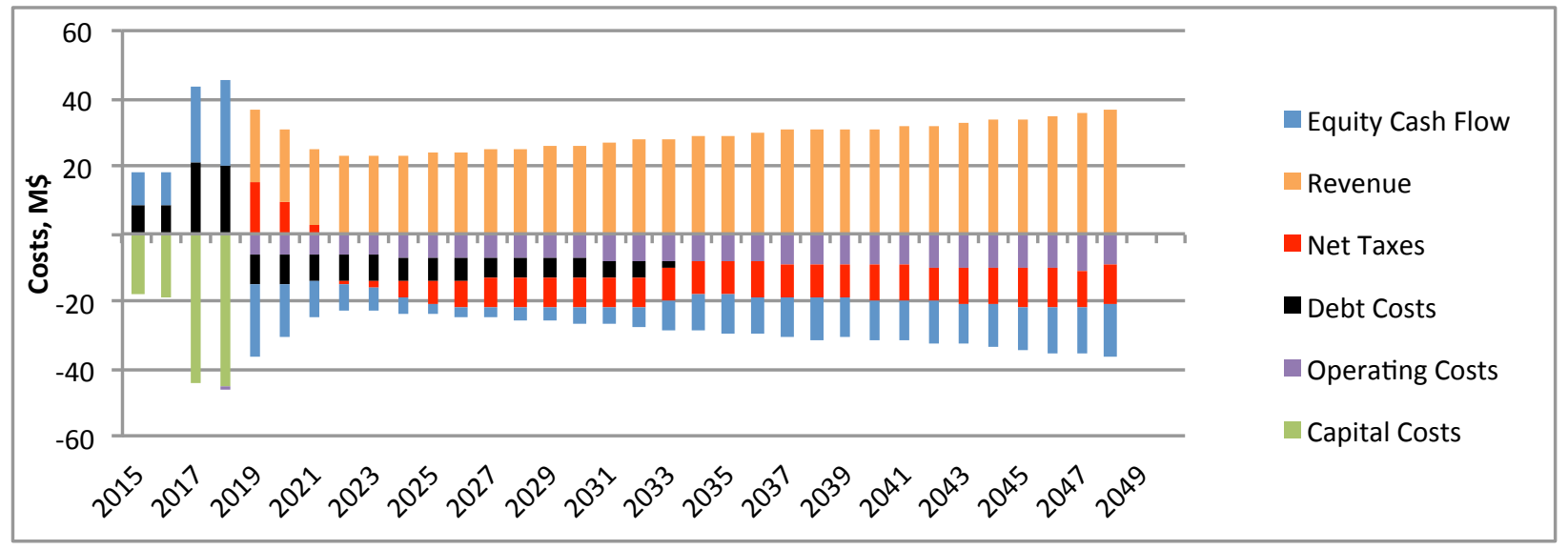

Figure 2. Project annual cash flow for Geothermal in Idaho. 


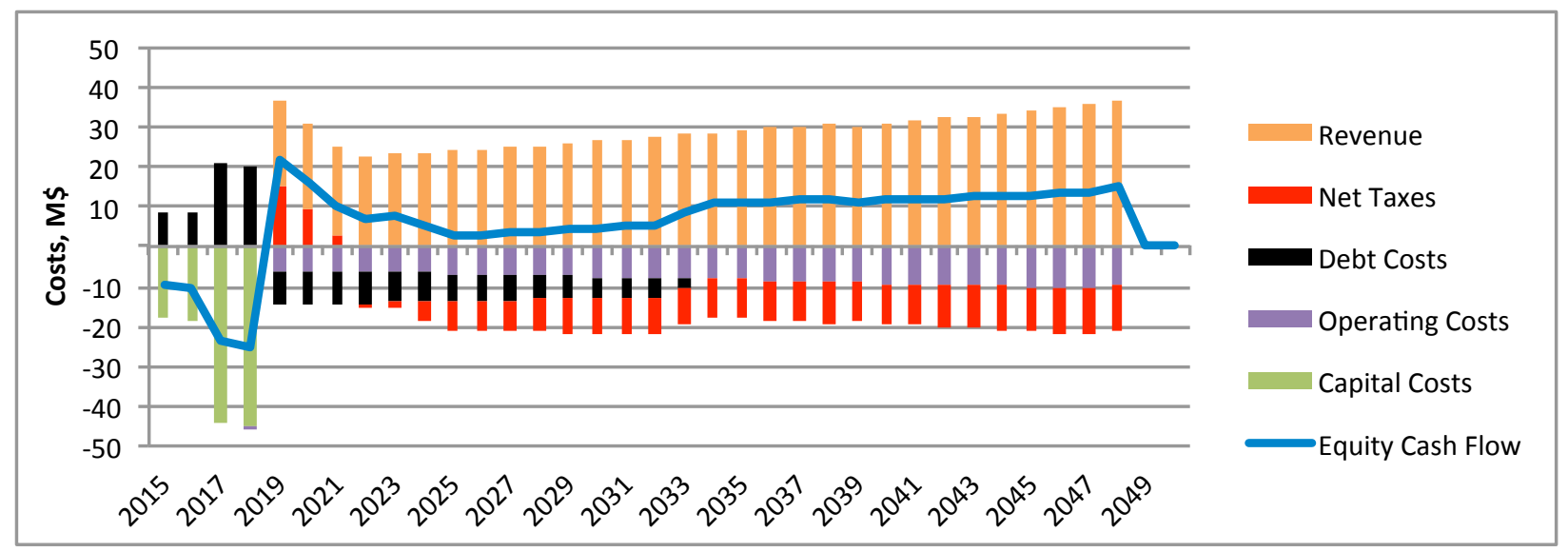

Figure 3. Equity annual cash flow for Geothermal in Idaho.

\subsection{OPERATION}

\subsubsection{Excel Operation}

The tool is contained within a single workbook with several sheets that contain the main results, calculations, various inputs, stored outputs, and data files for Tableau. On the main results sheet, called the Dashboard, some of the key variables for consideration, titles, descriptions, and flags for other inputs are included to identify the inputs to be used for the calculations. It also includes key output data and a chart for a specific region/case. A map presents color-coded results for all fifty states and a plot of the calculated price versus the state's input wholesale price. The map can show different results and even the difference between the current and any stored case.

On the left side of the Dashboard sheet are several macros that are used to run the tool. Essentially, the model internally calculates only for a single region and at a set price. The macros adjust the input price using an Excel goal-seek function so that the desired return on equity or return on debt + equity are achieved. The macros are split between running for just the one region (following any changes to inputs desired) and running the calculations for all states, storing the main results of each for the maps and charts. There are also two macro buttons for storing and loading cases.

\subsubsection{Tableau Operation}

Tableau operates in two ways: as standalone desktop software and as a server solution using a browser to connect with the end user. Because of the detailed calculations required, the tool also requires the operation of the R database software in server mode. Currently, the Tableau Connect server software can connect to the $\mathrm{R}$ server, but it has latency issues passing information between them and difficulties with multiple calls to R, so the desktop model is the most suitable for advanced interactive analysis. The server method works well for pre-computed scenarios that can be kept entirely within the Tableau software and that do not need R-server calculations. 


\section{FINMODULE CALCULATIONS}

\subsection{OVERALL STRUCTURE}

In Excel, the financial calculations largely flow down through the FINModule worksheet. All inputs used in the calculation are included at the top followed by sections calculating Revenue, Operating Costs, Assets, Debt, Taxes, Sale/Leaseback, and financial statements. At the bottom of the sheet, the inputs and key results for multiple regions are gathered for copying to the Storage worksheet. These areas are each described in sections below.

\section{$2.2 \quad$ INPUTS}

At the top of the FINModule worksheet are the input data used for the calculations. Those that are brown are entered on this sheet. Those in purple are from the Technology Inputs worksheet. Those in teal are from the State Inputs worksheet. Those in yellow are from the dashboard. These are explained in more detail in the subsequent chapters.

Also shown in yellow is the "Levelized Energy Price (\$MWh)" (LEP) in initial year \$. It represents the price for electricity in the initial year that escalates over the life of the fixed price period based on inflation and the price escalation factor. The value can vary for each state depending on the objective function selected for establishing prices, as described in Section 6.1. During normal viewing, it retrieves the price from the last time all fifty states were calculated to achieve the objective. However, on the Dashboard the user can select a price or have the model calculate a price either to meet the desired return on equity (ROE) or return on debt + equity $(\mathrm{ROD}+\mathrm{E})$. These calculate the energy price so that the net present value of total equity net cash flow equals $\$ 0$ when discounted at the input "Desired Return on Equity," or debt + equity net cash flow equals $\$ 0$ using the "Desired Return on Debt + Equity" on the Dashboard. Below the LEP is shown the Levelized Energy Price plus Renewable Energy Credit (REC) price (LEPR) that represents the full price the project receives for its production. (The model does not include any revenue for capacity nor ancillary services.)

The inputs on the FINModule sheet are shown in Table 1 and are largely financial and policy variables.

Table 1. Financial Inputs on FINModule

\begin{tabular}{|c|c|c|c|}
\hline Variable & $\begin{array}{l}\text { Representative } \\
\text { Value }\end{array}$ & Variable & $\begin{array}{l}\text { Representative } \\
\text { Value }\end{array}$ \\
\hline Fed. Income Tax Rate & $35 \%$ & Debt Ratio & $50 \%$ \\
\hline AMT/Carry Flag & No & Debt Max Life & 15 \\
\hline AMT Depreciation Life & 20 & Interest Rate & $6 \%$ \\
\hline General inflation rate & $2.0 \%$ & Debt Serv Resrve (\%year) & $50 \%$ \\
\hline Price Escal rate* & $0.0 \%$ & Work Cap \% of O\&M & $12.5 \%$ \\
\hline Constr Escal rate* & $0.0 \%$ & Sale/LeaseBack & No \\
\hline O\&M Escal rate* & $0.0 \%$ & Rent Coverage Ratio & $1.1 x$ \\
\hline \multirow{4}{*}{ Fuel Escal rate* } & $0.0 \%$ & Fixed Price Life & 20 \\
\hline & & REC Price Flag & National \\
\hline & & Natl REC Price, \$/MWh & 0 \\
\hline & & Carbon Cost, \$/T CO2 & 0 \\
\hline
\end{tabular}

* Escalation Rates are +/- general inflation

The federal income tax rate is the rate applied to net income before federal taxes (but after state taxes). It applies accelerated depreciation in the calculation of expenses, as explained in Section 2.7.1. The 
AMT/Carry Flag tells the model whether to apply an alternative minimum tax, carry forward early tax losses to later years to only offset taxable gains, or both. These are explained in Sections 2.7.4 and 2.7.5.

The General inflation rate applies to every future year as a base escalation factor to all costs and prices. In addition, various categories of costs and prices can be further escalated or de-escalated based on the four parameters below the general rate. For example, if general inflation is set at $2 \%$, entering a $-2 \%$ as the price escalation rate will offset this so that the energy price and REC price will not increase over time. System prices (used for years past the fixed price life) will also escalate at the general inflation plus price escalation rate. Any $\mathrm{CO}_{2}$ cost will be added to the system price based on the state's marginal carbon intensity calculated in StateInputs.

There are four debt-related inputs. The debt ratio sets the fraction of debt to total assets at the beginning of operation. The maximum life is period over which the debt is repaid. The interest rate is what is paid on debt. And the debt service reserve is the fraction of next year's debt costs (interest plus debt repayment) that must be set aside as an asset account. These are explained in more detail in Section 2.6. The working capital percent is similar in that it is the fraction of next year's fuel and operating and maintenance $(\mathrm{O} \& \mathrm{M})$ expenses that must be carried as an asset and is described in Section 2.5.

The Sale/Leaseback flag tells the model whether to do additional calculations to represent the developer selling the project to a third party at the start of operations and then lease the plant back. The rent coverage ratio is the inverse of the fraction of rent paid to the net operating income each year. More information is in Section 2.9.

The Fixed Price Life is the length of time that the project uses the input or calculated price to determine revenue from energy sales. Following that period, the project is assumed to sell power at the system average price. The project will continue to sell renewable energy credits throughout its lifespan. The REC Price flag tells the model whether to use the state-level REC prices as defined on the StateInputs sheet or whether to use the National REC Price listed in this input table. If they are set to National and $\$ 0 / \mathrm{MWh}$, then no RECs are sold by the project.

Lastly, a carbon cost is defined. Currently, this price is applied immediately to any carbon emissions by the project and increases at the rate of inflation plus any price escalation. This price is also added to the system costs using the marginal carbon intensity for the state.

The initial year is also set on this sheet. The model assumes that all cost and price inputs are put in that year's dollar value.

\subsection{REVENUE CALCULATION}

Production is calculated by checking if the plant is operating, and if so:

$$
\text { Production }=\text { Capacity } * 8760 \mathrm{hr} / \mathrm{yr} * \text { Capacity_Factor }
$$

Energy price $(\$ / \mathrm{MWh})$ is the escalated fixed price incorporating both inflation and escalation rates. Setting the price escalation to negative of the inflation gives a constant price over time.

$$
\text { Energy Price }=\text { Price }_{\text {year }-1} *(1+\text { inflation }+ \text { price escalation })
$$

Energy Sales Revenue (K\$) is the Production times the price divided by 1000 to put it in thousands of dollars $(\mathrm{K} \$)$. 
Similarly, RECs are calculated using the input REC price for a state, inflated and multiplied by the production.

Total revenue is the sum of the energy sales and REC sales. The tool currently does not include a capacity price in its revenue calculations. Regional system capacity prices are only available for certain regions of the country and have varied greatly between years. Availability of capacity-related revenue depends on a number of extraneous factors including the plant's availability to provide capacity on demand and multimarket pricing strategies of the owner.

\subsection{OPERATING COST CALCULATION}

Fuel costs in escalated $\$ / \mathrm{MWh}$ is calculated by conversion from fuel price to $\$ / \mathrm{mmBTU}$ and efficiency (in the input section) and escalating by inflation and any fuel escalation rate. This is multiplied by the production to get costs in thousand $\$(\mathrm{~K} \$)$.

$$
\begin{array}{lr}
\text { Fuel Price }_{\text {Yearone }}=\text { Fuel price }_{\left(\frac{\$}{m m B T U}\right) * \frac{3.412 m m b t u}{M W h} / \text { efficiency }} & \text { Eq. } 4 \\
\text { Fuel Price }=\text { Fuel Price }_{\text {year }-1} *(1+\text { inflation }+ \text { fuel escalation }) & \text { Eq. } 5 \\
\text { Fuel Cost }_{\text {year }}=\text { Fuel price }_{\text {year }} * \text { Production }_{\text {year }} / 1000 & \text { Eq. } 6
\end{array}
$$

Operating costs are input and allowed to have separate escalation rates for labor and materials. These costs are also input as both fixed $(\$ / \mathrm{kW})$ and variable $(\$ / \mathrm{MWh})$ in the inputs. Each cost factor is escalated and multiplied by production or capacity. Then they are summed to get the total O\&M cost. It is assumed that state labor and material taxes are imbedded in the O\&M cost input value. These are removed from the $\mathrm{O} \& \mathrm{M}$ costs by dividing by $(1+$ tax rate); the taxes are added later to the total state taxes by multiplying the amount by the tax rate.

$$
\begin{aligned}
& \text { O\&M Var. Price } \text { Yearone } \\
& \qquad=\text { O\&M Variable } \operatorname{Cost}\left(\frac{\$}{M W h}\right) \\
& *\left[\frac{\% \text { Labor }}{1+\text { LaborTax }}+\frac{\% \text { Material }}{(1+\text { MaterialTax })}\right]
\end{aligned}
$$

O\&M Fixed Price $_{Y e a r o n e}$

$$
=\text { O\&M Fixed Cost }\left(\frac{\$}{k W}\right) *\left[\frac{\% \text { Labor }}{1+\text { LaborTax }}+\frac{\% \text { Material }}{1+\text { MaterialTax }}\right] \quad \text { Eq. } 8
$$

O\&MVar.Price $=$ O\&M Var. Price $_{\text {year }-1} *(1+$ inflation $+O \& M$ escalation $) \quad$ Eq. 9

O\&M Fixed Price

$$
=\text { O\&M Fixed } \text { Price }_{\text {year }-1} *(1+\text { inflation }+ \text { O\&M escalation }) \quad \text { Eq. } 10
$$




$$
\begin{aligned}
& \text { o\&M Cost } \text { year }_{\text {o }}=\left(\text { o\&M Var. } \text { price }_{\text {year }} * \frac{\text { Production }_{\text {year }}}{1000}\right) \\
& +\left(\text { o\&M Fixed Price } \text { year } * \frac{\text { Production }_{\text {year }}}{\text { CapacityFactor } * 8760}\right)
\end{aligned}
$$

In Eq. 11 the fixed price is multiplied by production divided by the capacity factor and number of hours in the year so that it is only charged in the years the plant is operating.

\subsection{ASSET CALCULATION}

Assets for the project are those items of worth and can be physical assets or financial accounts. The PFMT summarizes these into five categories although more detailed financial models will have more categories.

$$
\text { Assets }=C W I P+N e t P \& E+W C+A F U D C+D S R
$$

where:

CWIP $=$ Construction Work in Progress

Net $\mathrm{P} \& \mathrm{E}=$ Net Plant and Equipment

$\mathrm{WC}=$ Working Capital

AFUDC $=$ Allowance for Funds Used During Construction

DSR $=$ Debt Service Reserves

CWIP and P\&E accounts contain the physical cost for project assets. These are calculated by summing the capital cost of the project during construction (properly escalating for inflation and other factors). To build up to these values, the annual capital outlays must be determined. The total capital cost in first year dollars is found by adjusting the average cost from the technology inputs worksheet (based on the technology selected) times the state cost factor for that technology (from the state inputs worksheet.)

$$
\text { Capital Cost }\left(\frac{\text { Yearone } \$}{k W}\right)=\text { Input capital cost } *(1+\text { State factor })
$$

The technology inputs include the years it takes to build the plant and a spending proportion per year up to the start of the plant. (This model assumes that production starts on January 1 of first year of production.) The input spending proportions total to $100 \%$, but these are all in first year $\$$. With inflation, the fractions in later years will increase based on the construction cost escalation plus general inflation. Their sum likely will not equal $100 \%$.

$$
\begin{aligned}
& \text { Capital (\%Yearone } \$)_{\text {year }} \\
& \quad=\text { Capital } \% \text { year } \\
& \quad *(1+\text { inflation }+ \text { construction escalation })^{\text {year-yearone }}
\end{aligned}
$$

Annual capital outlays are then the combination of capital cost per $\mathrm{kW}$, capacity, and spending stream. 


$$
\begin{aligned}
& \text { Capital outlay year } \\
& \qquad \text { Capital Cost }\left(\frac{\$}{k W}\right) * \text { Capital }(\% \text { Yearone } \$)_{\text {year }} \\
& * \text { Capacity (MW) }
\end{aligned}
$$

During construction, annual costs are placed into the CWIP account. Upon startup, they are transferred to the Gross Plant \& Equipment account. This account presents the total amount spent on plant and equipment. Depreciation then reduces the gross P\&E to create the Net P\&E. Book depreciation is defined as a straight-line depreciation over the life of the project with no residual value, so the annual depreciation is the Gross P\&E divided by the book life of the plant. Net Plant \& Equipment is the amount after depreciation is subtracted, and it represents the actual asset value at any point in time.

$$
\begin{aligned}
& \text { Gross P\&E }=\sum_{1}^{\text {Start of Operation }} \text { Capital outlay year } \\
& \text { Book Depreciation }_{\text {year }}=\text { Gross P\&E/Life } \quad \text { Eq. } 17 \\
& \text { Cumulative Depreciation } \text { year }_{\text {en }}
\end{aligned}
$$

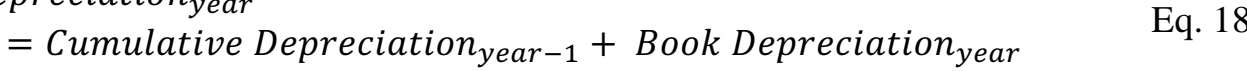

$$
\begin{aligned}
& \text { Net } P \& E_{\text {year }}=\text { Gross } P \& E_{\text {year }}-\text { Cumulative Depreciation }_{\text {year }}
\end{aligned}
$$

The developer may need to borrow funds during construction (as described in the next section). The interest payments during the construction are not expensed but rather accumulated and capitalized in the asset account Allowance for Funds Used During Construction (AFUDC). These costs are included in the asset value that receives the Investment Tax Credit. The accumulated costs are depreciated over the book life of the P\&E for both normal and taxable net income; accelerated depreciation for taxes does not apply.

In the years during construction, the change in AFUDC is simply the interest charges in that year, where interest is charged for a full year on the debt at the beginning of the year. After operation starts, no more debt is issued. (An earlier version included a half year of interest on new debt, but this added extra complications on several calculations and distortions on net present valuing.)

$$
\text { Interest }_{\text {year }}=i * D e b t_{\text {year }-1}
$$

where:

$$
\begin{aligned}
& \mathrm{i}=\text { Interest Rate } \\
& \text { Debt }_{\text {year-1 }}=\text { Debt level at end of previous year }
\end{aligned}
$$

So before operation,

$$
A F U D C_{\text {year }}=A F U D C_{\text {year }-1}+\text { Interest }_{\text {year }}
$$

After operation begins until debt is repaid,

$$
A F U D C_{\text {year }}=A F U D C_{\text {year }-1}-\frac{\text { Gross } A F U D C}{\text { Debt life }}
$$


Working capital is an asset that is the amount of funds needed on hand at the end of the year to pay for an input fraction of the next year's operating costs (fuel plus O\&M). The current example uses 45 days or $12.5 \%$, though this can be varied by the end user.

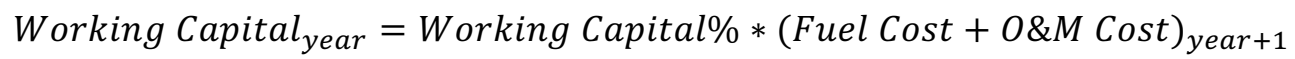

Change in working capital is simply the difference in working capital between the current and previous year and requires an infusion of cash flow to pay for any increase. In the year before operation, the bulk of these funds are collected. Smaller amounts are then collected each year as escalation drives up the operating costs. In the last year of operation, the asset value reduces to zero and the funds are used to pay a portion of the current year's operating costs.

The Debt Service Reserve (DSR) is the asset that represents the amount of funds needed to be kept in reserve to pay a fraction of the next year's interest charge and principal repayment. The current example uses $50 \%$ to represent six months in reserve, but this is modifiable in the inputs.

$$
D S R_{\text {year }}=\text { Debt Service Reserve } \% *(\text { Interest }+ \text { Debt Retired })_{\text {year }+1}
$$

Change in the reserve is simply the difference in the Debt Service Reserve between the current and previous year. In the year before operation, the largest amount of these funds is collected. During the life of the debt, the asset required is reduced (with lower interest payments) and the asset value declines. In the last year of the debt life, the remaining funds are used to pay a portion of the remaining debt and interest, and the asset value reduces to zero.

\subsection{DEBT CALCULATION}

Debt represents borrowed funds by the equity holder to help pay for the construction of the project. There could be several ways to calculate the amount of debt that can be issued. A simple method is to base it on an input fraction of total assets. For large firms with multiple projects, this fraction can be relatively constant, but with an individual project that has debt payments and lives shorter than the life of the facility, the ratio will vary over time. To simplify, the tool applies the input ratio to the asset value at the beginning of operation. As debt is paid off, this ratio will drop, going to zero once the debt is paid off.

As described above, assets consist of five categories: CWIP, Net P\&E, working capital, AFUDC, and debt service reserves. Although the first three categories are calculated strictly from the construction and operating costs and the AFUDC is based only on the debt level at the beginning of the year, the DSR is a function of the debt amount itself. This requires a more complex equation to determine the debt level at the end of each year.

$$
\text { Debt }_{\text {year }}=D R * \text { Assets }=D R *\left(P \& E_{\text {year }}+W C_{\text {year }}+A F U D C_{\text {year }}+D S R_{\text {year }}\right)
$$

where:

$$
\text { Debt }_{\text {year }}=\text { Debt level at End of Year }
$$

AFUDC is the collection of interest charges during construction (for later depreciation during operation) and is described in Section 2.5 above. Debt Service Reserves are also defined above. For calculating debt amounts during construction, the Debt Retired factor will only apply in the year before operation begins. Both factors include the debt amount, so they must be factored.

$$
\text { Interest }_{\text {year }+1}=i * \text { Debt }_{E O Y}
$$


The capital outlays for the next year are readily available. The change in working capital is also predefined. In the last year of construction, the project will build up its WC based on the operating costs, and in the first year of operation the amount will increase to reflect the escalation of operating costs. These equations can all be combined to form the equation for the final construction year as:

$$
\begin{array}{rl}
D e b t_{\text {year }}=D R & *\left(C W I P_{\text {year }}+P \& E_{\text {year }}+W C_{\text {year }}+A F U D C_{\text {year }}+D S R R\right. \\
& *\left(D e b t_{\text {year }} * i+\frac{\text { Debt }}{\text { lifear }}\right)
\end{array}
$$

where:

$$
\text { DSRR }=\text { Debt Service Reserve Required }(\%)
$$

This can be reconfigured so that in the last year of construction the debt level is defined as:

$$
\begin{array}{rl}
D e b t_{\text {year }}=D R & *\left(C W I P_{\text {year }}+P \& E_{\text {year }}+W C_{\text {year }}+A F U D C_{\text {year }}\right) /(1-D R * D S R R \\
& *\left(i+\frac{1}{\text { life }}\right)
\end{array}
$$

For the years prior to the final construction year, the factor 1/life does not apply, so it can be dropped from the equation. With the debt level determined, the debt issued each year can be calculated based on the difference between years. Once the project begins operating, the debt is retired in equal portions over the life of the debt. Depending on the revenue, operating costs, taxes, and other factors, there may be years during operation when additional capital is needed to pay all cash outflows, but this is assumed to come from new equity rather than new debt.

\subsection{TAX CALCULATION}

\subsubsection{Tax Depreciation}

The developer/operator may take advantage of U.S. Internal Revenue Service (IRS) rules in Publication 946 (IRS 2015) that allow for a more rapid depreciation than what is used in the regular financial books when calculating taxes, both in terms of the length of time to fully depreciate and the schedule of depreciation amounts. This is referred to as the Modified Accelerated Cost Recovery System (MACRS). Under MACRS, depreciable property has a tax depreciation life over which its cost is recovered of $3,5,7,10,15,20,27.5$, or 31.5 years, depending on the type of property, and through use of statutory recovery methods. The property's class life or book depreciation life represents the length of its life for its general books (using normalized, straight line depreciation) while its MACRS life uses a declining balance method, either a double-declining balance method if the tax life is less than 15 years and a one-and-a-half declining balance for tax lives of 15 years or greater. The equation is:

\section{Depreciation Double $=[$ Gross P\&E - Cum.Tax Depreciation $] \times 2$ / Tax Depreciation Life}

Note: One-and-a-half declining balance would use 1.5 instead of 2 in the equation.

The tax code requires that the calculation assume that the plant starts in the middle of the first year of operation for tax depreciation. For example, a plant with a 5-year tax life would have depreciation of $20 \%$ 
of its value in the first year. In the second year, the amount would be $32 \%$ ( $40 \%$ of the remaining $80 \%$.) The third year would be $19.2 \%$ ( $40 \%$ of the remaining $48 \%$.)

The double-declining balance equation depreciates an asset as a function of the undepreciated balance, so it never fully depreciates an asset. To compensate, the amount of depreciation using straight-line depreciation is also calculated. This straight-line calculation, however, only uses the net value of the plant and the years remaining in the tax life of the plant. Toward the end of the tax life, the straight-line value is higher than the double declining balance value. Once it becomes higher, this straight-line depreciation is used instead.

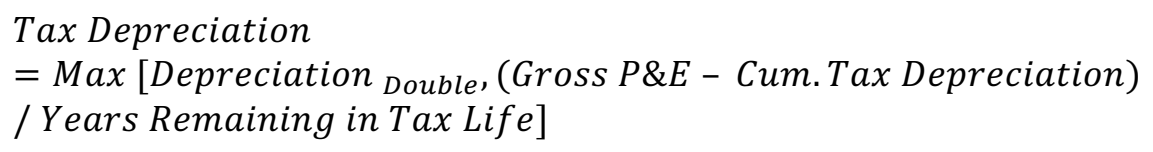

To continue the example, in the fourth year the double-declining balance method sets the depreciation at $11.52 \%$. The straight-line depreciation of the remaining $28.8 \%$ of the asset over two and a half years is also $11.52 \%$. In the fifth year, the double-declining balance equation gives only $6.9 \%$; the straight-line value of $11.52 \%$ is used again. In year 6 , the final $5.76 \%$ is depreciated.

\subsubsection{Tax Credit Calculations}

There are two main types of tax credits available in the model: investment tax credits and production tax credits. These are available at both the state and federal level. The production tax credit (PTC) is a credit applied on the basis of the production of the project. Current federal rules allow it for the first ten years of operation, and it escalates at the inflation rate over this period. Currently, wind projects are the main beneficiary of these credits; geothermal and closed-loop biomass have also been eligible, but future projects are less likely to be so. Biomass only qualified for half of the PTC that others did. The values for any technology can be changed by the user to understand their impact.

The Investment Tax Credit (ITC) applies only to solar and geothermal, with solar plants at $30 \%$ and geothermal at $10 \%$. Wind plants can take the ITC instead of the PTC, but it is up to the user to pick one to use. This amount is scheduled to drop to $10 \%$ for solar projects constructed post-2016, but the tool currently has a value of $30 \%$ for their reference. The values for any technology can be changed by the user to understand their impact.

The ITC is only applicable to specialized components of the project and not to such things as land, substations, liens. To account for this, an input variable call "ITC Applicable Capital" is allowed, currently set at $90 \%$ as a rough approximation. Another factor of consideration is that with the provision of the ITC, there is less capital to be depreciated for tax purposes. Currently, the model reduces the taxable asset by half of the ITC amount. This lowers the amount of MACRS depreciation and so lessens the impact of the ITC on the tax bill.

\subsubsection{Income Tax Calculation}

An income statement for tax purposes is created to determine the taxes payable. The net income before income taxes is the revenue minus expenses (fuel, O\&M, interest, depreciation). Rather than straight-line book depreciation, the depreciation is based on using the accelerated depreciation of the project. This means that plants with high depreciation due to accelerated depreciation may show a profit on the regular income statement, but they will have large losses on the tax income statement. These losses are what are carried forward in the tax calculation. 
In addition, state taxes (such as state-related non-income taxes) are removed. The model assumes that prices include collection of these taxes, but these are not taxable income since they must be paid to the state. The model then calculates the resulting state income taxes from the equation:

$$
\begin{aligned}
& \text { Current State income taxes } \\
& =(\text { Revenues }- \text { operating expense }- \text { interest }- \text { tax depreciation } \quad \text { Eq. } 31 \\
& \text { - other state taxes)* state income tax rate } \\
& \text { Current federal income taxes } \\
& =(\text { Revenues }- \text { operating expense }- \text { interest }- \text { tax depreciation } \\
& \text { - other state taxes - current state income taxes) } \\
& \text { * federal income tax rate }
\end{aligned}
$$

Deferred taxes represent those taxes that would have been paid if the book depreciation was used for tax calculation instead of the MACRS depreciation.

$$
\begin{aligned}
& \text { Deferred income taxes } \\
& \quad=(\text { tax depreciation }- \text { book depreciation }) \\
& \quad *(\text { federal income tax rate }+ \text { state income tax rate })
\end{aligned}
$$

This accumulates in the early years when tax depreciation is higher than book depreciation, and then decreases to zero once the tax life of the asset has been passed so that tax deprecation equals zero. The accumulated deferred taxes appear on the balance sheet as a liability since it must eventually be paid like any other debt. However, this liability has no interest charge associated with it, so it represents how accelerated depreciation is a type of no-interest loan.

\subsubsection{Alternative Minimum tax}

The tool has the option to apply an Alternative Minimum Tax (AMT) on the profits of the project. It can be important if a corporation relies too much on tax benefits such as accelerated depreciation to lower its tax bill. The AMT reduces those tax advantages but uses a lower tax rate in calculating the alternative tax. The model calculates tax depreciation using the longer depreciation life specified in the tax code. It then determines an AMT Income based on normal revenues, expenses, and this new depreciation amount. It multiplies the AMT Income by $20 \%$ to find the AMT. If this amount is higher than the regular tax that would have been paid (or a smaller tax credit for operating losses), the AMT is used instead of the regular tax.

$$
\begin{aligned}
& \text { Alternative Minimum Tax } \\
& \qquad \begin{array}{l}
=(\text { Revenues - Alternative Depreciation } \\
- \text { Other Expenses }) \times 20 \%
\end{array}
\end{aligned}
$$

Current Taxes Payable

= Maximum (Regular Current Taxes, Alternative Minimum Tax)

\subsubsection{Carry Forward Calculation}

Carryforward of operating losses is required if the equity holder does not have sufficient offsetting positive taxes elsewhere in its operations to use these operating losses. In this case, it must carry the losses forward until they can be used to offset positive taxes. Although tax law allows a carryback and carryforward of losses, with carryback preferred, the model uses only carryforward of losses. This is 
because losses generally occur at startup before there are positive taxes to offset the losses. The credits are not carried on the balance sheet as receivables but only taken as extraordinary gains if used.

For example, in year $t$, suppose net income before income taxes: is $-\$ 100 \mathrm{~K}$, with state and federal income taxes of $-\$ 6 \mathrm{~K}$ and $-\$ 33 \mathrm{~K}$, respectively. Because taxes could not be negative, the $-\$ 39 \mathrm{~K}$ would be carried forward to apply against any positive taxes in the next year. In year $t+1$, net income before income taxes is again $-\$ 100 \mathrm{~K}$. The resultant $-\$ 39 \mathrm{~K}$ in taxes would also be carried forward. In year $t+2$, net income is

$+\$ 60 \mathrm{~K}$. Taxes would be $\$ 23 \mathrm{~K}$. The model would use the carryforward from year $t$ to offset these positive taxes first. This would leave year $t$ carryforward at $-\$ 16 \mathrm{~K}$ and year $t+1$ at $-\$ 39 \mathrm{~K}$. At the end of year $t+15$, any part of the remaining $-\$ 16 \mathrm{~K}$ that had not been used to offset taxes would be lost to the corporation.

\subsection{COMBINED EQUITY CASHFLOW}

The combined equity cash flow section brings together the different cash revenues and expenses to determine the net revenue that equity holders would see. The "combined" includes both the lessor and lessee as a single entity if the sale/leaseback option is chosen. The worksheet breaks the calculation into two parts, the cash outflows and cash inflows (Table 2).

Table 2. Cash Outflows and Inflows for Project Cash Flow

\begin{tabular}{|c|c|}
\hline \multicolumn{1}{|c|}{ Cash Outflows } & Cash Inflows \\
\hline Capital Outlays (Capital costs) & Energy Sales (Revenue) \\
\hline Fuel Costs (Operating Costs) & Renewable Energy Credit Sales (Revenue) \\
\hline O\&M Costs (Operating Costs) & State Tax Credits (Net Taxes) \\
\hline Change in Working Capital (Operating Costs) & Federal Tax Credits (Net Taxes) \\
\hline Change in Debt Service Acct (Debt Costs) & Debt Issued (Debt Costs) \\
\hline Interest (Debt Costs) & Stock Issued (Equity Cash Flow) \\
\hline Debt Retired (Debt Costs) & \\
\hline Federal Taxes (Net Taxes) & \\
\hline State/Local Taxes (Net Taxes) & \\
\hline Property Tax (Net Taxes) & \\
\hline Dividends Paid (Equity Cash Flow) & \\
\hline
\end{tabular}

All of these costs are placed into the six main categories shown in Figure 1 on page 3 as indicated in the parentheses in Table 2. The sum of all cash outflows will equal the cash inflows in every year.

Rearranging this to get the perspective of the equity shareholder, dividends paid minus stock issued will equal the remaining cash inflows minus cash outflows.

\subsection{SALE/LEASE CALCULATION}

With a sale/leaseback, the idea is that the project operator builds the plant, borrowing funds as needed. Upon completion, he or she sells the plant to a third party, along with the debt associated with it, and then leases the plant back from the new owner.

The total cash flow of the two parties is the same as the equity cash flow above. An additional transaction of rent is made between the two to balance the costs. The amount of rent is based on an input Rent Coverage Ratio that represents the amount of net operating income the lessee must have above the rent amount. The equation for the rent calculation is: 


$$
\text { Rent }=\frac{\text { Revenue }- \text { fuel cost }- \text { O\&M cost }}{\text { Rent Coverage Ratio }}
$$

The lessor purchases the plant (along with the AFUDC and debt service reserve account) and takes over the debt from the lessee in the final year of construction. Rent is charged annually based on the net operating income (revenue - fuel - operating costs) times an input rent coverage ratio, typically a factor around 1.1. A macro button is included at the top of FINModule to calculate a coverage ratio that gives the lessee the desired ROE. If the consolidated equity is also receiving that return, then the lessor will also. There is a $10 \%$ rent prepayment equal to $10 \%$ of the tax depreciation in the last year of construction as well. The lessor is then responsible for paying all debt costs but receives the tax credit and accelerated depreciation benefits. Taxes paid are based on revenue from rent less depreciation, interest, and property taxes.

The lessee must pay for the capital construction plus costs during construction, but is reimbursed by the lessor when the plant assets and debts are sold prior to operations. The lessee then sells the power and RECs, and pays the operating costs, rent, other state-related taxes except property taxes, emissions taxes, and income taxes based on these revenues and costs. The lessee receives the revenue from any production tax credit. The primary asset of the lessee is just the working assets account since other assets have been transferred to the lessor.

\subsection{FINANCIAL STATEMENTS}

The financial statements for the consolidated owner of the project (the combination of the lessor and lessee) are calculated for each year, consisting of an income statement, balance sheet, and sources and uses of funds statement.

\subsubsection{Income Statement}

The income statement tracks the revenues and costs that are to be expensed each year. Table 3 shows a representative statement for the construction and first three years of a project. Capitalized costs, such as construction and interest during construction, are expensed through depreciation over the life of the project. Both taxes that are payable and taxes deferred are shown, although only the first category involves physical cash flow. At the bottom of the income statement, the dividend payout is subtracted to show the amount that is added to or subtracted from the retained earnings in the balance sheet. During construction, all costs are capitalized and no revenues are received, so no taxes or net income.

\subsubsection{Balance Sheet}

The balance sheet presents the assets, liabilities, and equity in the project for each year. Table 4 shows a representative statement for the construction and first three years of a project. As evidenced by the name, assets should balance against the liabilities and equity. Assets include CWIP (which ae transferred to the Gross P\&E at the start of operation), the Gross P\&E less the accumulated depreciation, the AFUDC, and the two capital accounts, working capital (to cover a portion of next year's operating costs) and Debt Service Account (that covers a portion of the next year's interest on debt and debt repayment).

Liabilities represent those external claims on the assets of the project, in this case the outstanding debt and the accumulated taxes that have been deferred. The tax deferrals are due to the accelerated depreciation allowed in the tax code. When calculating the taxes payable in a given year, the accelerated depreciation means that there are higher expenses and so less net income in the early years, with a consequent lower tax bill. However, the income statement for financial calculations use the regular, straight-line 
depreciation so taxes would have been higher. The difference between what was paid and what would have been paid with straight-line depreciation represents the deferred taxes.

Table 3. Example Income Statement for Large PV project (K\$)

\begin{tabular}{|c|c|c|c|c|c|}
\hline & 2015 & 2016 & 2017 & 2018 & 2019 \\
\hline \multicolumn{6}{|l|}{ Revenues } \\
\hline Electricity Sales & 0 & 0 & 21,693 & 22,127 & 22,570 \\
\hline Renewable Energy Credits & 0 & 0 & 3,927 & 4,005 & 4,085 \\
\hline $\begin{array}{ll}\text { Total } \\
\end{array}$ & 0 & 0 & 25,620 & 26,132 & 26,655 \\
\hline \multicolumn{6}{|l|}{ Expenses } \\
\hline - Fuel Costs & 0 & 0 & 0 & 0 & 0 \\
\hline - O\&M Costs & 0 & 0 & 3,847 & 3,924 & 4,002 \\
\hline - Depreciation & 0 & 0 & 9,956 & 9,956 & 9,956 \\
\hline - Depreciation of AFUDC & 0 & 0 & 188 & 188 & 188 \\
\hline - Interest & 0 & 0 & 9,438 & 8,809 & 8,179 \\
\hline Total Expenses & 0 & 0 & 23,428 & 22,876 & 22,325 \\
\hline Pre-Tax Income & 0 & 0 & 2,192 & 3,256 & 4,330 \\
\hline - Property Taxes & 0 & 0 & 2,015 & 1,946 & 1,876 \\
\hline - State/Local Taxes & 0 & 0 & 943 & 962 & 981 \\
\hline - CO2 Emission Cost & 0 & 0 & 0 & 0 & 0 \\
\hline - Fed Income Taxes Payable & 0 & 0 & $-14,816$ & $-25,245$ & $-13,311$ \\
\hline - Deferred Income Taxes & & & 15,027 & 25,846 & 14,305 \\
\hline - Less Tax credits & 0 & 0 & $-82,163$ & 0 & 0 \\
\hline Net Income & 0 & 0 & 81,185 & -253 & 477 \\
\hline Less: Dividend Payout & 0 & 0 & 96,174 & 25,555 & 14,745 \\
\hline Add to Retained Earnings & 0 & 0 & $-14,989$ & $-25,808$ & $-14,267$ \\
\hline
\end{tabular}

Table 4. Sample Balance Sheet for Large PV project (K\$)

\begin{tabular}{|c|c|c|c|c|c|}
\hline & 2015 & 2016 & 2017 & 2018 & 2019 \\
\hline \multicolumn{6}{|l|}{ Assets: } \\
\hline CWIP & 29,340 & 298,681 & 0 & 0 & 0 \\
\hline Gross Plant \& Equip & 0 & 0 & 298,681 & 298,681 & 298,681 \\
\hline - Accumulated Depreciation & 0 & 0 & $-9,956$ & $-19,912$ & $-29,868$ \\
\hline AFUDC & 454 & 5,626 & 5,439 & 5,251 & 5,064 \\
\hline Working Capital & 0 & 481 & 490 & 500 & 510 \\
\hline Debt Service Acct & 2,586 & 9,962 & 9,648 & 9,333 & 9,018 \\
\hline Total & 32,380 & 314,751 & 304,302 & 293,854 & 283,405 \\
\hline \multicolumn{6}{|l|}{ Liabilities: } \\
\hline Debt & 15,124 & 157,297 & 146,810 & 136,324 & 125,837 \\
\hline Deferred Taxes & 0 & 0 & 15,027 & 40,872 & 55,178 \\
\hline Total & 15,124 & 157,297 & 161,837 & 177,196 & 181,015 \\
\hline \multicolumn{6}{|l|}{ Equity: } \\
\hline Stock Outstanding & 17,256 & 157,454 & 157,454 & 157,454 & 157,454 \\
\hline Retained Earnings & 0 & 0 & $-14,989$ & $-40,797$ & $-55,064$ \\
\hline Total & 17,256 & 157,454 & 142,465 & 116,657 & 102,390 \\
\hline Total Liability + Equity & 32,380 & 314,751 & 304,302 & 293,854 & 283,405 \\
\hline
\end{tabular}


The amount of debt will decrease over the input life of the debt (e.g., 15 years) and be zero for the latter years. The deferred taxes will climb during the early years and then decline to zero in the last year of the project.

Equity represents the remaining investment by equity holders in the project. As stock is issued during construction, this amount will increase. Rather than buy back stock, the tool assumes that excess funds are paid out as dividends during times of excess cash. In some situations, there may be times when revenues from sales do not cover cash expenses, such as when debt is being repaid based on the straight-line schedule, and deferred taxes are also being paid. In these cases, additional stock must be issued and no dividends paid.

\subsubsection{Sources/Uses of Funds}

The last table shows the sources and uses of funds for each year. Table 5 shows a representative statement for the construction and first three years of a project. It is organized somewhat differently from the cash flows described in Table 2 because it begins with the net income as the first source of funds. Since the net income includes some non-cash items (depreciation and deferred taxes), these are added back into the amount to show the cash from operations. Debt and stock issued is also added to calculate the net sources of cash. Uses include the payment of dividends, increases in assets, and debt retirement. As with the balance sheet, the two categories must equal each other.

Table 5. Sample Sources and Uses of Funds Statement for Large PV

\begin{tabular}{|c|c|c|c|c|c|}
\hline & 2015 & 2016 & 2017 & 2018 & 2019 \\
\hline \multicolumn{6}{|l|}{ Sources: } \\
\hline Net Income & 0 & 0 & 81,185 & -253 & 477 \\
\hline + Depreciation of P\&E & 0 & 0 & 9,956 & 9,956 & 9,956 \\
\hline + Depreciation of AFUDC & 0 & 0 & 188 & 188 & 188 \\
\hline + Deferred Taxes & 0 & 0 & 15,027 & 25,846 & 14,305 \\
\hline Cash from Operations & 0 & 0 & 106,355 & 35,737 & 24,926 \\
\hline Debt Issued & 15,124 & 142,173 & 0 & 0 & 0 \\
\hline Stock Issued & 17,256 & 140,198 & 0 & 0 & 0 \\
\hline Net Sources & 32,380 & 282,371 & 106,355 & 35,737 & 24,926 \\
\hline \multicolumn{6}{|l|}{ Uses: } \\
\hline Dividends & 0 & 0 & 96,174 & 25,555 & 14,745 \\
\hline Increase in Gross Plant & 29,340 & 269,341 & 0 & 0 & 0 \\
\hline Increase in AFUDC & 454 & 5,173 & 0 & 0 & 0 \\
\hline Increase in Working Capital & 0 & 481 & 10 & 10 & 10 \\
\hline Increase in Debt Service Acct & 2,586 & 7,376 & -315 & -315 & -315 \\
\hline Debt Retirement & 0 & 0 & 10,486 & 10,486 & 10,486 \\
\hline Net Uses & 32,380 & 282,371 & 106,355 & 35,737 & 24,926 \\
\hline
\end{tabular}




\subsection{DATA FOR STORAGE AND DASHBOARD}

At the bottom of the FINModule is a section with a restatement of the inputs and key outputs (summarized cash-flow values, fixed prices) for each state. The outputs are used in the Dashboard, and both the inputs and outputs are copied to the StoredOutputs worksheet so that reference or sensitivity cases can be stored, either for comparison on the Dashboard or to be reloaded to be able to regenerate case results. Up to twenty cases can be stored and loaded using the macros on the Dashboard. 


\section{REGIONAL DATA INPUTS}

State-level inputs are for those variables that have different values among the states, so that the individual differences can be incorporated into the calculation. There are two worksheets that maintain these inputs. The StateIncent worksheet is a collection of incentives that are applicable to renewable energy projects based largely on the DSIRE database funded by DOE and maintained by the North Carolina Clean Energy Technology Center (NC State 2015). The second worksheet (StateInputs) aggregates the multiple incentives into applicable values for each state based on the technology and sector, and stores tax rates and power prices within each state, as well as technology- and state-specific data such as capital cost factors and capacity factors (CFs).

\subsection{STATE INCENTIVES FROM DSIRE}

The DSIRE database (NC Clean Energy Technology Center, 2015) is an online search tool that lists the hundreds of incentives available in the different states for renewable energy and energy efficiency. An ORNL researcher has combed the database to find applicable incentive programs and has recorded key parameters that can be used by PFMT concerning state level ITC and PTC incentives, tax abatements, state REC prices, applicable technologies, sectors, size, and expiration dates. For each incentive recorded, the webpage address and date the data were entered into the site is recorded to allow confirmation of the entry.

Because each entry may only apply to certain projects in the state, a calculation is made as to whether it applies to the project being calculated. If so, the appropriate incentive parameters are calculated and passed to the StateInputs worksheet. On that sheet, all of the records in the Incentives sheet are scanned since there can be multiple entries for the project within each state. These get consolidated to a single summary row for the project for each state.

\subsection{OTHER STATE-LEVEL INPUTS}

Multiple state-level tax rates can be modeled in PFMT. A property tax can be set that uses either the net book value or gross book value. The rates currently in the model are based on data from Table 35 of 50-State Property Tax Comparison Study from the Lincoln Institute of Land Policy and Minnesota Taxpayers Association (Lincoln 2011). These data are for rural industrial property taxes in 2010 from representative towns in each state for property values over $\$ 25$ million, and so they are only approximate for all projects.

The tool also has a variable for taxes on labor inputs, energy inputs, and material inputs. The last one is also used in the model to calculate a sales tax on power sales. Currently, the tool has the labor and energy amounts equal to zero while the material tax is based on 2015 sales tax values reported by Tax-Rates.org (Tax-Rates.org 2015). State average corporate income tax rates are also taken from this site. The site reports a range of values for some states; in these case, the higher of the values is used as the input.

State-level electricity wholesale or marginal prices are also input. These were found for each of the major electrical regions (Figure 4) by downloading the Federal Energy Regulatory Commission (FERC) Form-714 data for all of the balancing area authorities (FERC 2015). Each year, all balancing authorities must submit their "Annual Electric Balancing Authority Area and Planning Area Report." These electronic data, among other information, give the "system lambda" for each hour of the previous year. The system lambda is defined as:

For balancing authority areas where demand following is primarily performed by thermal generating units, the system lambda is derived from the economic dispatch function associated 
with automatic generation control performed at the balancing authority area's controlling utility or pool control center. Excluding transmission losses, the fuel cost $(\$ / \mathrm{hr})$ for a set of on-line and loaded thermal generating units (steam and gas turbines) is minimum when each unit is loaded and operating at the same incremental fuel cost $(\$ / \mathrm{MWh})$ with the sum of the unit loadings (MW) equal to the system demand plus the net of interchange with other balancing authority areas. This single incremental cost of energy is the system lambda. (FERC 2015)

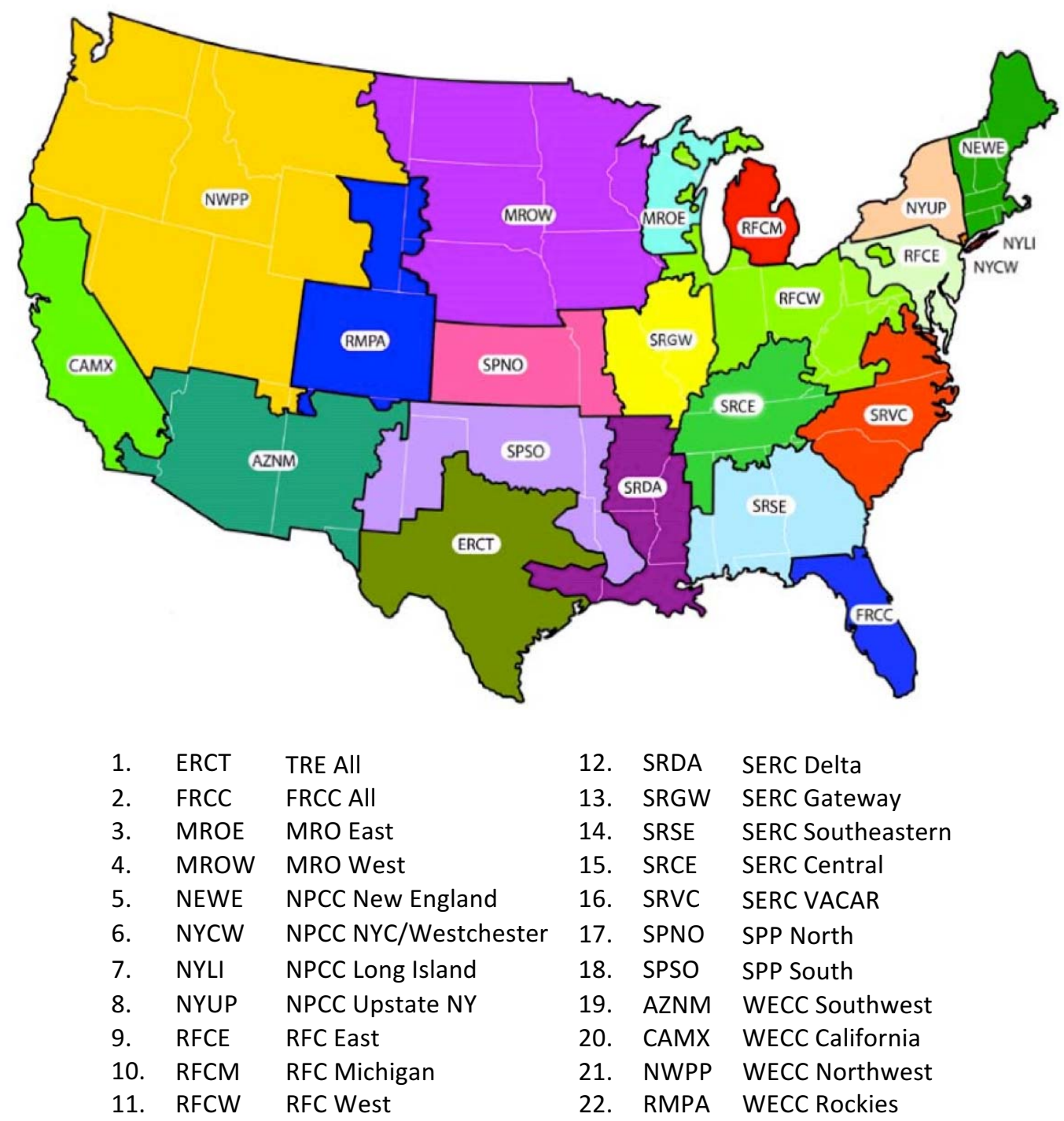

Figure 4. Electricity Market Model Regions. Source EIA.

The average cost for the year is found by simply taking the average of all 8,760 hourly values. Not all authorities submitted prices. The database presents the identification (ID) code for within the Energy Information Administration (EIA) datasets. Cross referencing to the datasets allows one to establish the EIA region to which each authority belongs. The list of prices by authority, and associated North American Electric Reliability Corporation region, are shown in Table 6. 
Table 6. Balancing Authority Average System Lambda for 2014 and Applicable Region

\begin{tabular}{|c|c|c|c|}
\hline EIA ID & Utility & $\begin{array}{l}\text { Average System } \\
\text { Lambda } 2014\end{array}$ & Region \\
\hline 5723 & ERCOT & 36.90 & ERCT \\
\hline 18445 & City of Tallahassee & 26.93 & FRCC \\
\hline 6452 & Florida Power \& Light Company & 28.44 & FRCC \\
\hline 9617 & JEA & 32.48 & FRCC \\
\hline 18454 & Tampa Electric Company & 33.49 & FRCC \\
\hline 14610 & Florida Municipal Power Pool & 34.45 & FRCC \\
\hline 6909 & Gainesville Regional Utilities & 35.03 & FRCC \\
\hline 6455 & Progress Energy (Florida Power Corp.) & 35.86 & FRCC \\
\hline 21554 & Seminole Electric Cooperative, Inc. & 38.67 & FRCC \\
\hline 56669 & MISO & 37.77 & $\begin{array}{l}\text { MORE, MROW, RFCM, } \\
\text { RFCW, SRDA, SRGW }\end{array}$ \\
\hline 13434 & ISO New England Inc. & 63.32 & NEWE \\
\hline 13501 & New York Independent System Operator, Inc. & 46.94 & NYCW, NYLI, NYUP \\
\hline 14725 & PJM Interconnection LLC & 48.21 & RFCE, RFCW, SRVC \\
\hline 189 & $\begin{array}{l}\text { PowerSouth Energy Cooperative (Alabama Electric } \\
\text { Cooperative, Inc.) }\end{array}$ & 33.19 & SRSE \\
\hline 11249 & Louisville Gas \& Electric and Kentucky Utilities & 27.64 & SRCE \\
\hline 18642 & Tennessee Valley Authority & 31.39 & SRCE \\
\hline 3046 & Progress Energy (Carolina Power \& Light Company) & 44.49 & SRCE \\
\hline 5416 & Duke Energy Carolinas, LLC & 36.47 & SRVC \\
\hline 17543 & South Carolina Public Service Authority & 43.54 & SRVC \\
\hline 17690 & Southwest Power Pool (SPP) & 32.41 & SPNO, SPSO \\
\hline 803 & Arizona Public Service Company & 27.80 & AZNM \\
\hline 9216 & Imperial Irrigation District & 32.75 & AZNM \\
\hline 18195 & Southern Company & 37.40 & AZNM \\
\hline 5701 & El Paso Electric Company & 40.20 & AZNM \\
\hline 16572 & Salt River Project & 41.64 & AZNM \\
\hline 24211 & Tucson Electric Power Company & 42.54 & AZNM \\
\hline 13407 & Nevada Power Company & 63.19 & AZNM \\
\hline 11208 & Los Angeles Department of Water and Power & 34.30 & CAMX \\
\hline 19281 & Turlock Irrigation District & 44.86 & CAMX \\
\hline 15473 & Public Service Company of New Mexico & 41.66 & NWPP \\
\hline 17166 & Sierra Pacific Resources & 48.36 & NWPP \\
\hline 15466 & Public Service Company of Colorado & 26.94 & RMPA \\
\hline 599 & Anchorage Municipal Light \& Power & 31.86 & AK \\
\hline 3522 & Chugach Electric Association, Inc. & 53.28 & AK \\
\hline 19547 & Hawaiian Electric Company, Inc. & 161.83 & $\mathrm{HI}$ \\
\hline
\end{tabular}

Not all authorities submitted system lambdas, but enough did that all regions are covered, some with just a single authority, some with multiple ones. Some authorities, such as SPP and MISO, cover multiple regions. For simplicity, regional prices were simply the average of the lambdas of all authorities in the region. There are additional sources of data for authorities within open markets (e.g., California ISO), but those data were not included at this time.

Regional prices were assigned to individual states by calculating the proportion of demand provided by each region within a state and applying the costs from Table 6 to that proportion, then determining an average. The proportions were found by using the 2014 retail sales as listed both by region (from EIA's Annual Energy Outlook 2015) and by state (from EIA's Annual Electricity Report). Four matrices with regions along the top and states in the rows are created. Matrix 1is a sparse matrix with the fractions of regions applied to each state, as shown in Table 7. The sum across each row for each state totals 1.0. 
Table 7. Matrix of calculated proportions of regional sales in each state

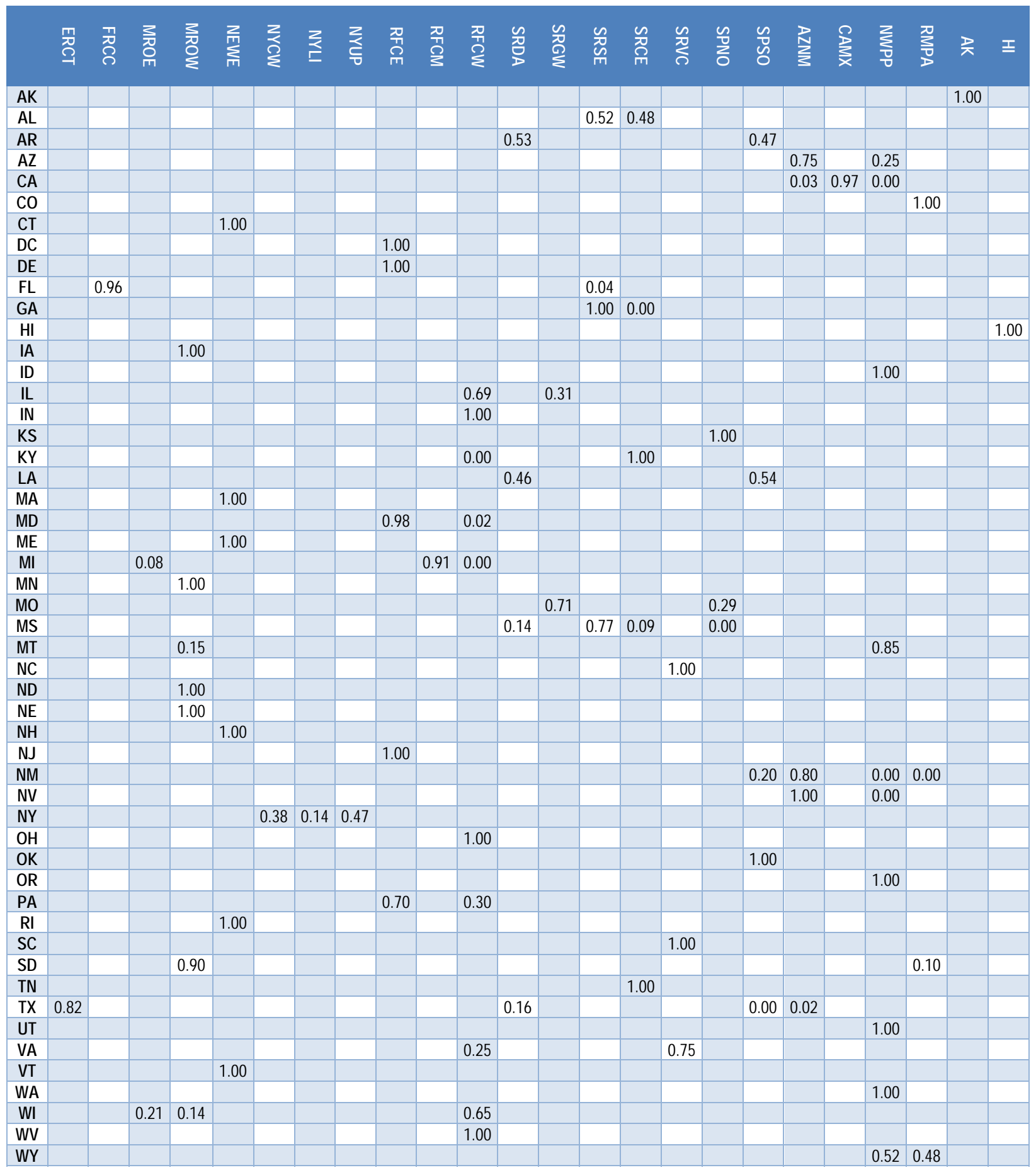

These fractions were derived by creating three additional tables. Matrix 2 multiplies each state's demands for 2014 (from the Electric Power Annual) by the fractions in the first matrix to get a matrix of the sales by state and region. These are summed at the bottom of each column to get the total sales assigned to each region, based on the fractions. Matrix 3 then divides the sales by this sum of the column to create the fraction of demand in that region from each state. These should sum to 1.0 for each column. Lastly, the 
third matrix's fractions are multiplied by the annual sales by region (from the Annual Energy Outlook) to create an alternate estimate of sales in each region by state.

A calculation is performed to find the sum of the square of the difference between each cell in Matrix 2 and Matrix 4. The cell values in Matrix 1 (Table 7) are manipulated using Excel's Solver function to minimize this value thereby creating the "best fit" for the regional proportions for each state. Lastly, the average system lambdas for each region are multiplied by the values in Matrix 1 to calculate the average marginal cost for each state. These are copied to the input table in the StateInputs worksheet.

\subsection{TECHNOLOGY-SPECIFIC FACTORS}

\subsubsection{Capacity Factors}

The technology-specific CFs for each state and technology are also listed in StateInputs. The CF for solar $\mathrm{PV}$ is found by using data from the AEO2015. Values for each region by month and hour of the day are listed in the input file solarin.txt from the Annual Energy Outlook 2015. These factors were converted to annual values for each electricity market region by multiplying by the number of hours per month, summing, and dividing by 8,760. Applying these CFs by the fractions in Table 7 and then summing each row gives the average $\mathrm{CF}$ for each state.

The onshore wind CF was determined using data from NREL and AWS TruPower that was used in the 2010-2015 Eastern Interconnection Transmissions Study (EIPC 2013). It provides six data sets that list the potential wind resource (capacity and generation amounts) for each state at 80 - and $100-\mathrm{m}$ tower heights and with CFs greater than 30\%, 35\%, and 40\%. The reference (NREL and TruPower 2011) is a publicly available display of the data for a $\mathrm{CF} \geq 30 \%$ and hub height of $80 \mathrm{~m}$. As expected, there is less resource available at higher $\mathrm{CFs}$, and some states have no resources at the higher $\mathrm{CFs}$. Higher turbine heights provided higher CFs. Since the PFMT is only considering a single representative project, a state does not need a large resource base to have a potential project built. However, if resources are limited at high CFs, then lower CF sites are more likely to be used. We set a minimum level of 1,000 MW of available resource from any of these combinations of hub heights and CF to select the appropriate CF. If the amount of resource was below that amount, then the next lower height and/or minimum CF level was selected. For example, Table 8 shows the resource and average $\mathrm{CF}$ for different tower heights and minimum CF. The highest CF occurs for the $80-\mathrm{m}$ height with $>40 \% \mathrm{CF}$, but there is only $667 \mathrm{MW}$ of potential resource in the state. Therefore, the next highest CF, 43\%, is used in PFMT. Some states did not have sufficient resources available in any of the categories, and therefore they had the CF set at $1 \%$ (to avoid any division errors elsewhere in the tool.)

Table 8. Potential Onshore Wind Resource and Capacity Factor for New York. Source: NREL

\begin{tabular}{|c|c|c|c|c|c|c|}
\hline & $\begin{array}{c}80 \mathrm{M}, \\
>40 \% \mathrm{CF}\end{array}$ & $\begin{array}{c}80 \mathrm{M}, \\
>35 \% \mathrm{CF}\end{array}$ & $\begin{array}{c}80 \mathrm{M}, \\
>30 \% \mathrm{CF}\end{array}$ & $\begin{array}{l}100 \mathrm{M} \\
>40 \mathrm{CF}\end{array}$ & $\begin{array}{c}100 \mathrm{M}, \\
>35 \% \mathrm{CF}\end{array}$ & $\begin{array}{c}100 \mathrm{M}, \\
>30 \% \mathrm{CF}\end{array}$ \\
\hline Potential Capacity (MW) & 667 & 4,805 & 25,781 & 3,205 & 20,418 & 57,639 \\
\hline Capacity Factor & $44 \%$ & $38 \%$ & $33 \%$ & $43 \%$ & $38 \%$ & $34 \%$ \\
\hline
\end{tabular}

Offshore wind CFs were found from the EIPC study inputs, namely Exhibit 11 of Appendix A of the assumptions document. (CRA 2010) It provides capacity factors for regions and states with significant offshore wind potential. The geothermal CFs will differ by state for those states that have current capacity, implying that future plants could be added at the same capacity factor. Gas combined cycle, gas combustion turbine, nuclear, and biomass CFs are based on the AEO2015 assumptions. The same values are used for every state since these are not presumed to vary. 


\subsubsection{Capital Costs Adjustments}

In 2010, EIA commissioned R.W. Beck Inc. to create a reference data source for a number of generating technologies (EIA 2010) to be used in the National Energy Modeling System (NEMS). Among other parameters, R.W. Beck Inc. created tables of the construction cost variations by location for each technology. Although much of their data are relatively dated, these factors are assumed not to have changed significantly in the intervening years. 
Table 9. Capital Cost Location Percent Variation (EIA 2010)

\begin{tabular}{|c|c|c|c|c|c|c|c|c|}
\hline & Large PV & Small PV & $\begin{array}{l}\text { Onshore } \\
\text { Wind }\end{array}$ & $\begin{array}{l}\text { Offshore } \\
\text { Wind }\end{array}$ & Biomass & Geo-thermal & Gas CC & Gas CT \\
\hline AK & $27.5 \%$ & $26.0 \%$ & $39.0 \%$ & $7.8 \%$ & $14.3 \%$ & $21.1 \%$ & $34.5 \%$ & $44.6 \%$ \\
\hline $\mathbf{A L}$ & $-7.5 \%$ & $-7.5 \%$ & $-4.5 \%$ & $0.0 \%$ & $-6.7 \%$ & $0.0 \%$ & $-9.3 \%$ & $-4.1 \%$ \\
\hline AR & $-6.6 \%$ & $-6.5 \%$ & $-3.6 \%$ & $0.0 \%$ & $-6.0 \%$ & $0.0 \%$ & $-8.1 \%$ & $-2.9 \%$ \\
\hline$A Z$ & $-5.7 \%$ & $-5.7 \%$ & $-3.1 \%$ & $0.0 \%$ & $0.0 \%$ & $-3.7 \%$ & $1.7 \%$ & $-2.3 \%$ \\
\hline CA & $10.4 \%$ & $10.0 \%$ & $13.2 \%$ & $4.3 \%$ & $7.6 \%$ & $6.0 \%$ & $23.8 \%$ & $18.3 \%$ \\
\hline $\mathrm{CO}$ & $-3.2 \%$ & $-3.4 \%$ & $2.0 \%$ & $0.0 \%$ & $-12.9 \%$ & $-3.4 \%$ & $1.3 \%$ & $2.3 \%$ \\
\hline CT & $6.5 \%$ & $6.2 \%$ & $7.2 \%$ & $5.2 \%$ & $11.3 \%$ & $0.0 \%$ & $26.5 \%$ & $23.1 \%$ \\
\hline DC & $3.8 \%$ & $3.5 \%$ & $8.4 \%$ & $1.9 \%$ & $14.8 \%$ & $0.0 \%$ & $32.1 \%$ & $36.4 \%$ \\
\hline $\mathrm{DE}$ & $3.9 \%$ & $3.7 \%$ & $5.0 \%$ & $2.9 \%$ & $9.4 \%$ & $0.0 \%$ & $25.0 \%$ & $22.9 \%$ \\
\hline FL & $-6.0 \%$ & $-5.9 \%$ & $-3.8 \%$ & $0.0 \%$ & $-5.2 \%$ & $0.0 \%$ & $-7.9 \%$ & $-3.7 \%$ \\
\hline GA & $-8.5 \%$ & $-8.4 \%$ & $-5.2 \%$ & $-8.1 \%$ & $-7.5 \%$ & $0.0 \%$ & $-7.7 \%$ & $-0.8 \%$ \\
\hline HI & $43.4 \%$ & $40.5 \%$ & $30.1 \%$ & $13.8 \%$ & $28.1 \%$ & $27.2 \%$ & $47.9 \%$ & $71.5 \%$ \\
\hline IA & $-0.5 \%$ & $-0.7 \%$ & $3.5 \%$ & $0.0 \%$ & $-3.2 \%$ & $0.0 \%$ & $-2.0 \%$ & $0.6 \%$ \\
\hline ID & $-1.7 \%$ & $-2.0 \%$ & $3.2 \%$ & $0.0 \%$ & $-4.5 \%$ & $-3.3 \%$ & $-4.6 \%$ & $-1.9 \%$ \\
\hline IL & $16.9 \%$ & $16.5 \%$ & $15.2 \%$ & $14.7 \%$ & $12.5 \%$ & $0.0 \%$ & $15.1 \%$ & $11.0 \%$ \\
\hline IN & $-1.7 \%$ & $-1.7 \%$ & $-0.2 \%$ & $-1.8 \%$ & $-0.4 \%$ & $0.0 \%$ & $0.0 \%$ & $2.1 \%$ \\
\hline KS & $-3.7 \%$ & $-3.9 \%$ & $1.7 \%$ & $0.0 \%$ & $-6.0 \%$ & $0.0 \%$ & $-4.9 \%$ & $-0.9 \%$ \\
\hline KY & $-6.1 \%$ & $-6.0 \%$ & $-3.6 \%$ & $0.0 \%$ & $-5.2 \%$ & $0.0 \%$ & $-5.9 \%$ & $-3.2 \%$ \\
\hline LA & $-10.2 \%$ & $-10.1 \%$ & $-6.5 \%$ & $0.0 \%$ & $-8.8 \%$ & $0.0 \%$ & $-5.9 \%$ & $3.3 \%$ \\
\hline MA & $13.3 \%$ & $13.0 \%$ & $11.6 \%$ & $11.6 \%$ & $17.0 \%$ & $0.0 \%$ & $37.1 \%$ & $33.1 \%$ \\
\hline MD & $-2.1 \%$ & $-2.3 \%$ & $1.4 \%$ & $-2.8 \%$ & $-0.6 \%$ & $0.0 \%$ & $18.8 \%$ & $19.1 \%$ \\
\hline $\mathrm{ME}$ & $-2.5 \%$ & $-2.8 \%$ & $6.2 \%$ & $-3.8 \%$ & $-4.0 \%$ & $0.0 \%$ & $-4.0 \%$ & $0.1 \%$ \\
\hline MI & $-0.6 \%$ & $-0.6 \%$ & $0.7 \%$ & $-0.6 \%$ & $-0.6 \%$ & $0.0 \%$ & $1.5 \%$ & $2.8 \%$ \\
\hline MN & $8.2 \%$ & $7.9 \%$ & $9.6 \%$ & $6.5 \%$ & $4.1 \%$ & $0.0 \%$ & $6.3 \%$ & $5.6 \%$ \\
\hline MO & $2.0 \%$ & $1.9 \%$ & $2.3 \%$ & $0.0 \%$ & $1.2 \%$ & $0.0 \%$ & $2.9 \%$ & $3.4 \%$ \\
\hline MS & $-7.0 \%$ & $-6.9 \%$ & $-4.2 \%$ & $0.0 \%$ & $-6.2 \%$ & $0.0 \%$ & $-8.7 \%$ & $-3.7 \%$ \\
\hline MT & $-0.6 \%$ & $-0.9 \%$ & $4.5 \%$ & $0.0 \%$ & $0.0 \%$ & $0.0 \%$ & $-2.1 \%$ & $1.3 \%$ \\
\hline NC & $-8.6 \%$ & $-8.5 \%$ & $-4.9 \%$ & $-8.3 \%$ & $-7.4 \%$ & $0.0 \%$ & $-8.2 \%$ & $-4.1 \%$ \\
\hline ND & $-3.4 \%$ & $-3.6 \%$ & $2.2 \%$ & $0.0 \%$ & $-6.0 \%$ & $0.0 \%$ & $-5.4 \%$ & $-1.6 \%$ \\
\hline NE & $-0.6 \%$ & $-0.8 \%$ & $3.6 \%$ & $0.0 \%$ & $-3.4 \%$ & $0.0 \%$ & $-1.8 \%$ & $1.0 \%$ \\
\hline NH & $0.3 \%$ & $0.0 \%$ & $5.4 \%$ & $0.0 \%$ & $-2.8 \%$ & $0.0 \%$ & $6.3 \%$ & $-0.7 \%$ \\
\hline NJ & $14.2 \%$ & $14.0 \%$ & $12.4 \%$ & $13.3 \%$ & $11.7 \%$ & $0.0 \%$ & $22.2 \%$ & $21.0 \%$ \\
\hline NM & $-1.2 \%$ & $-1.5 \%$ & $3.8 \%$ & $0.0 \%$ & $0.0 \%$ & $-2.4 \%$ & $-3.0 \%$ & $3.2 \%$ \\
\hline NV & $7.9 \%$ & $7.6 \%$ & $9.4 \%$ & $0.0 \%$ & $0.0 \%$ & $3.1 \%$ & $5.1 \%$ & $4.1 \%$ \\
\hline NY & $15.5 \%$ & $15.1 \%$ & $14.1 \%$ & $13.6 \%$ & $13.1 \%$ & $0.0 \%$ & $40.6 \%$ & $36.4 \%$ \\
\hline $\mathrm{OH}$ & $-4.8 \%$ & $-4.8 \%$ & $-2.8 \%$ & $0.0 \%$ & $-2.5 \%$ & $0.0 \%$ & $-2.7 \%$ & $0.5 \%$ \\
\hline OK & $-3.7 \%$ & $-3.9 \%$ & $1.7 \%$ & $0.0 \%$ & $-6.0 \%$ & $0.0 \%$ & $-4.9 \%$ & $-0.9 \%$ \\
\hline OR & $5.9 \%$ & $5.5 \%$ & $8.9 \%$ & $4.9 \%$ & $3.0 \%$ & $1.9 \%$ & $12.7 \%$ & $4.6 \%$ \\
\hline PA & $2.5 \%$ & $2.5 \%$ & $2.3 \%$ & $0.0 \%$ & $1.9 \%$ & $0.0 \%$ & $11.3 \%$ & $8.6 \%$ \\
\hline $\mathbf{R I}$ & $2.8 \%$ & $2.7 \%$ & $2.4 \%$ & $2.4 \%$ & $2.0 \%$ & $0.0 \%$ & $21.1 \%$ & $16.4 \%$ \\
\hline SC & $-11.4 \%$ & $-11.3 \%$ & $-6.8 \%$ & $-11.1 \%$ & $-10.1 \%$ & $0.0 \%$ & $-12.9 \%$ & $-5.9 \%$ \\
\hline SD & $-5.4 \%$ & $-5.5 \%$ & $0.9 \%$ & $0.0 \%$ & $-7.7 \%$ & $0.0 \%$ & $-7.4 \%$ & $-2.8 \%$ \\
\hline TN & $-9.3 \%$ & $-9.2 \%$ & $-5.6 \%$ & $0.0 \%$ & $-7.9 \%$ & $0.0 \%$ & $-9.1 \%$ & $-5.1 \%$ \\
\hline TX & $-9.3 \%$ & $-9.2 \%$ & $-5.9 \%$ & $-8.7 \%$ & $-7.8 \%$ & $0.0 \%$ & $-9.4 \%$ & $-5.8 \%$ \\
\hline UT & $-1.8 \%$ & $-2.1 \%$ & $4.0 \%$ & $0.0 \%$ & $0.0 \%$ & $-3.1 \%$ & $-3.9 \%$ & $-0.1 \%$ \\
\hline VA & $-4.9 \%$ & $-4.9 \%$ & $-1.1 \%$ & $-4.7 \%$ & $-1.0 \%$ & $0.0 \%$ & $4.3 \%$ & $4.4 \%$ \\
\hline VT & $-3.2 \%$ & $-3.4 \%$ & $3.2 \%$ & $0.0 \%$ & $-5.7 \%$ & $0.0 \%$ & $-1.0 \%$ & $4.9 \%$ \\
\hline WA & $2.8 \%$ & $2.6 \%$ & $5.1 \%$ & $2.2 \%$ & $1.2 \%$ & $0.9 \%$ & $2.0 \%$ & $2.9 \%$ \\
\hline WI & $0.9 \%$ & $0.8 \%$ & $1.2 \%$ & $0.6 \%$ & $1.9 \%$ & $0.0 \%$ & $2.3 \%$ & $3.1 \%$ \\
\hline WV & $-1.4 \%$ & $-1.4 \%$ & $0.0 \%$ & $0.0 \%$ & $-1.7 \%$ & $0.0 \%$ & $0.3 \%$ & $2.3 \%$ \\
\hline WY & $-2.2 \%$ & $-2.5 \%$ & $4.3 \%$ & $0.0 \%$ & $0.0 \%$ & $-3.3 \%$ & $-1.2 \%$ & $4.9 \%$ \\
\hline
\end{tabular}




\section{TECHNOLOGY INPUTS}

\subsection{TECHNOLOGIES SELECTED}

The model can evaluate multiple types of technologies. Currently eight technology options have been identified as shown in Table 10. Below each technology name are listed the current values used for the input variables within the model.

Table 10. Technology Inputs

\begin{tabular}{|c|c|c|c|c|c|c|c|c|}
\hline Tech Options & Large PV & Small PV & $\begin{array}{l}\text { Onshore } \\
\text { Wind }\end{array}$ & $\begin{array}{l}\text { Offshore } \\
\text { Wind }\end{array}$ & Biomass & $\begin{array}{c}\text { Geotherm } \\
\text { al }\end{array}$ & Gas CC & Gas CT \\
\hline Technology & Solar & Solar & Wind & Wind & Biomass & $\begin{array}{c}\text { Geotherma } \\
\text { I }\end{array}$ & Gas & Gas \\
\hline Capacity, MW & 150 & 7 & 100 & 400 & 150 & 50 & 400 & 210 \\
\hline Sector & $\begin{array}{l}\text { Commer- } \\
\text { cial }\end{array}$ & $\begin{array}{l}\text { Commer- } \\
\text { cial }\end{array}$ & $\begin{array}{l}\text { Commer- } \\
\text { cial }\end{array}$ & $\begin{array}{l}\text { Commer- } \\
\text { cial }\end{array}$ & $\begin{array}{c}\text { Commer } \\
\text { cial }\end{array}$ & Commercia & $\begin{array}{l}\text { Commer- } \\
\text { cial }\end{array}$ & $\begin{array}{l}\text { Commer- } \\
\text { cial }\end{array}$ \\
\hline Prod Tax Credit, \$/MWh & 0 & 0 & 23 & 23 & 11 & 23 & 0 & 0 \\
\hline $\begin{array}{l}\text { Fed Investment Tax } \\
\text { Credit }\end{array}$ & $30 \%$ & $30 \%$ & $0 \%$ & $30 \%$ & $0 \%$ & $10 \%$ & $0 \%$ & $0 \%$ \\
\hline ITC Applicable Capital & $90 \%$ & $90 \%$ & $90 \%$ & $90 \%$ & $90 \%$ & $90 \%$ & $90 \%$ & $90 \%$ \\
\hline Tax Depreciation Life & 5 & 5 & 5 & 5 & 5 & 5 & 20 & 15 \\
\hline Capital Cost, \$/kW & 2000 & 2200 & 2016 & 6267 & 3726 & 2493 & 1036 & 683 \\
\hline Operating Life, years & 30 & 30 & 30 & 30 & 30 & 30 & 30 & 30 \\
\hline Book Depreciation Life & 30 & 30 & 30 & 30 & 30 & 30 & 30 & 30 \\
\hline Var. O\&M Cost, \$/MWh & 0.00 & 0.00 & 0.00 & 0.00 & 5.36 & 0.00 & 3.33 & 10.56 \\
\hline Fix O\&M Cost, \$/kW & 25.13 & 25.13 & 40.26 & 75.32 & 107.52 & 114.93 & 15.64 & 7.17 \\
\hline O\&M - Labor \% & $50 \%$ & $50 \%$ & $50 \%$ & $50 \%$ & $50 \%$ & $50 \%$ & $50 \%$ & $50 \%$ \\
\hline O\&M - Matl \% & $50 \%$ & $50 \%$ & $50 \%$ & $50 \%$ & $50 \%$ & $50 \%$ & $50 \%$ & $50 \%$ \\
\hline Fuel Cost, \$/mmBTU & 0.00 & 0.00 & 0.00 & 0.00 & 3.00 & 0.00 & 3.00 & 3.00 \\
\hline Thermal Efficiency, \% & $36 \%$ & $36 \%$ & $36 \%$ & $36 \%$ & $25 \%$ & $36 \%$ & $54 \%$ & $40 \%$ \\
\hline CO2 Emissions, $\mathrm{T} / \mathrm{MWh}$ & 0.00 & 0.00 & 0.00 & 0.00 & 0.00 & 0.00 & 0.34 & 0.45 \\
\hline Years to Construct & 2 & 1 & 3 & 4 & 4 & 4 & 3 & 2 \\
\hline \multicolumn{9}{|l|}{ Year before Operation } \\
\hline-7 & $0 \%$ & $0 \%$ & $0 \%$ & $0 \%$ & $0 \%$ & $0 \%$ & $0 \%$ & $0 \%$ \\
\hline-6 & $0 \%$ & $0 \%$ & $0 \%$ & $0 \%$ & $0 \%$ & $0 \%$ & $0 \%$ & $0 \%$ \\
\hline-5 & $0 \%$ & $0 \%$ & $0 \%$ & $0 \%$ & $0 \%$ & $0 \%$ & $0 \%$ & $0 \%$ \\
\hline-4 & $0 \%$ & $0 \%$ & $0 \%$ & $5 \%$ & $15 \%$ & $15 \%$ & $0 \%$ & $0 \%$ \\
\hline-3 & $0 \%$ & $0 \%$ & $5 \%$ & $10 \%$ & $30 \%$ & $15 \%$ & $25 \%$ & $0 \%$ \\
\hline-2 & $10 \%$ & $0 \%$ & $10 \%$ & $30 \%$ & $40 \%$ & $35 \%$ & $50 \%$ & $65 \%$ \\
\hline-1 & $90 \%$ & $100 \%$ & $85 \%$ & $55 \%$ & $15 \%$ & $35 \%$ & $25 \%$ & $35 \%$ \\
\hline
\end{tabular}

The data values can come from a variety of sources. There are a number of similar studies that publish data such as this, though occasionally it may be in a slightly different format. For example, dollar values may be some earlier year's basis rather than 2015 purchasing power, or thermal efficiency may be given as a heat rate value. Table 11 describes each of the parameters in more detail and provides references for the values. 
Table 11. Description and sources of technology data

\begin{tabular}{|c|c|c|}
\hline Variable & Description & Source \\
\hline Tech Name & Label used for selecting the technology & \\
\hline Technology & $\begin{array}{l}\text { Type of Technology - used for evaluating } \\
\text { applicability of state incentives }\end{array}$ & \\
\hline Capacity, MW & $\begin{array}{l}\text { Capacity of project - used for evaluating } \\
\text { applicability of state incentives and total costs }\end{array}$ & \\
\hline Sector & $\begin{array}{l}\text { Residential, Commercial or Industrial - used for } \\
\text { evaluating applicability of state incentives }\end{array}$ & \\
\hline $\begin{array}{l}\text { Prod Tax Credit, } \\
\$ / \mathrm{MWh}\end{array}$ & $\begin{array}{l}\text { Prod Tax Credit, } \$ / M W h-\text { National production tax } \\
\text { credit in } 2015 \$\end{array}$ & $\begin{array}{l}\text { Assumptions to AEO2015 (Energy } \\
\text { Information Administration, 2015) }\end{array}$ \\
\hline $\begin{array}{l}\text { Fed Investment Tax } \\
\text { Credit }\end{array}$ & National credit, applies to certain renewables & $\begin{array}{l}\text { Assumptions to the AEO2015 (Energy } \\
\text { Information Administration, 2015) and the } \\
\text { NREL Annual Technology Basis (Blair, et al. } \\
\text { 2015) (ITC may lower to } 10 \% \text { after 2016.) }\end{array}$ \\
\hline ITC Applicable Capital & $\begin{array}{l}\text { Represents percentage of total capital cost that } \\
\text { qualifies for the ITC. Does not include supporting } \\
\text { structures and common equipment }\end{array}$ & \\
\hline Tax Depreciation Life & $\begin{array}{l}\text { Modified Accelerated Cost Recovery System } \\
\text { (MACRS) life for calculating expensing of facility for } \\
\text { tax calculations, based on IRS rules }\end{array}$ & $\begin{array}{l}\text { Assumptions to AEO2015 (Energy } \\
\text { Information Administration, 2015) } \\
\text { IRS Publication } 946\end{array}$ \\
\hline Capital Cost, \$/kW & $\begin{array}{l}\text { National average capital cost applied to facility, } \\
\text { adjusted by state }\end{array}$ & $\begin{array}{l}\text { Assumptions to AEO2015 (Energy } \\
\text { Information Administration, 2015) except } \\
\text { solar based on extrapolation of LBNL 2011- } \\
2014 \text { costs (Bolinger \& Seel, 2015)(Barbose } \\
2015 \text { ) and } 10 \% \text { increase for small utility PV }\end{array}$ \\
\hline Operating Life, years & Operating Life, years & $\begin{array}{l}\text { Assumptions to AEO2015 (Energy } \\
\text { Information Administration, 2015) }\end{array}$ \\
\hline $\begin{array}{l}\text { Book Depreciation } \\
\text { Life }\end{array}$ & Book Depreciation Life & $\begin{array}{l}\text { Assumptions to AEO2015 (Energy } \\
\text { Information Administration, 2015) }\end{array}$ \\
\hline $\begin{array}{l}\text { Var. O\&M Cost, } \\
\$ / \mathrm{MWh}\end{array}$ & Var. O\&M Cost, \$/MWh & $\begin{array}{l}\text { Assumptions to AEO2015 (Energy } \\
\text { Information Administration, 2015) }\end{array}$ \\
\hline Fix O\&M Cost, \$/kW & Fix O\&M Cost, $\$ / \mathrm{kW}$ & $\begin{array}{l}\text { Assumptions to AEO2015 (Energy } \\
\text { Information Administration, 2015) }\end{array}$ \\
\hline O\&M - Labor \% & O\&M - Labor \% & Arbitrary split of $50 \%$ \\
\hline O\&M - Matl \% & O\&M - Matl \% & Arbitrary split of $50 \%$ \\
\hline Fuel Cost, $\$ / \mathrm{mmBTU}$ & Fuel Cost, $\$ / \mathrm{mmBTU}$ & NREL ATB (Blair, et al. 2015) \\
\hline Thermal Efficiency, \% & Thermal Efficiency, \% & $\begin{array}{l}\text { Assumptions to AEO2015 (Energy } \\
\text { Information Administration, 2015) }\end{array}$ \\
\hline $\begin{array}{l}\mathrm{CO}_{2} \text { Emissions, } \\
\mathrm{T} / \mathrm{MWh}\end{array}$ & $\mathrm{CO}_{2}$ Emissions, $\mathrm{T} / \mathrm{MWh}$ & $\begin{array}{l}\text { Calc from efficiency and conversion } \\
53.07 \mathrm{KgCO}_{2} / \mathrm{mmBTU} \text { for gas (EIA 2016) }\end{array}$ \\
\hline Years to Construct & Years to Construct & $\begin{array}{l}\text { Assumptions to AEO2015 (Energy } \\
\text { Information Administration, 2015) }\end{array}$ \\
\hline
\end{tabular}

The capital costs used are largely based on inputs from the EIA AEO2015 inputs. The geothermal costs are reflective of expansion of current plants rather than greenfield sites, so only current states are applicable for projects. Future PFMT analyses could utilize greenfield sites and expand into newer states, but these plants are two to four times more expensive, according to the NREL Annual Technology Baseline (NREL 2015). Because solar PV costs are changing rapidly, its capital costs are based on the cost reduction rate between 2011 and 2014 as reported in LBNL's reports (Bolinger \& Seel, 2015) (Barbose 2015) extrapolated to 2017. 


\section{PFMT USING TABLEAU SOFTWARE}

The PFMT tool using Tableau software currently provides two types of solutions. The first solution requires the installation of the Tableau Desktop 9 standalone software and $\mathrm{R}$ on the same machine and then accessing the PFMT tableau workbook (PFMT_Vxx.twbx) file. The second solution is by providing access to the tool as a pre-computed scenario workbook on Tableau server. A user needs to have an account to be able to log in to the server via any web browser to access PFMT. Below is the description of these two solutions, also highlighting their pros and cons.

\subsection{TABLEAU DESKTOP SOLUTION}

The section below first describes how to install Tableau Desktop 9 and $\mathrm{R}$ on a Windows/Mac machine and then describes the $\mathrm{R}$ integration process with Tableau to perform the calculations. Finally, all the input parameters, calculated outputs, and the dashboards created are discussed in detail.

\subsubsection{Tableau Desktop 9 Installation}

When you purchase Tableau, you will receive a welcome email that explains what you need to do to download and install the software. Use the included user name and password to log into the Customer Portal so you can download the software and your product key. Follow the instructions below to download and install your products.

Step 1: Sign in to the Tableau Customer Portal using your email address and the password provided by Tableau.

Step 2: Click the My Keys link.

Step 3: In the Products Key column, copy the product key for the Tableau product you want to install. Step 4: Under Product Downloads, click the link to the product you want to download.

Step 5: On Windows computers, you will be prompted to save or run Tableau Desktop.exe. On a Mac, TableauDesktop.dmg is copied to your Download folder.

Step 6: On Windows, when the download finishes, double-click the installer file to begin the installation. Follow the on-screen instructions to install the product.

On a Mac, you will be prompted to drag the Tableau Desktop icon to your Applications folder:

Step 7: When you are done installing Tableau, you will need to activate and register the product. Click Activate the product.

Step 8: Click the text box and press Ctrl $+\mathrm{V}(\mathrm{Cmd}-\mathrm{V}$ on a Mac) to paste your product key. You can also right-click (control-click on a Mac) in the text box and select Paste. When finished, click Activate.

Important: If you are upgrading versions and have paid your maintenance since the last time you completed off-line activation, contact Tableau Customer Service first. If you are working offline, refer to the Offline Activation Help article for information on how to activate Tableau.

Step 9: Click the Register button to continue with the registration process.

Step 10: Register the product by typing your name, company, email address, and any other necessary information. Then click the Register button.

Step 11: When registration is successful, click Continue to start using the product. 


\subsubsection{R Setup for Tableau Desktop}

This section explains how to set up the R statistical package on the same Windows machine as the Tableau Desktop installation.

1. In a web browser, go to www.r-project.org.

2. Find where you select a CRAN Mirror. Click the link and select a site that is reasonably close to where you are located. This just means you will download the $\mathrm{R}$ installer from somewhere relatively close.

3. After selecting the CRAN mirror site, click the link to download the R installer for Windows. Save the download file to your local hard drive.

4. You are done with the browser portion.

5. Double-click on the saved $\mathrm{R}$ installer to install the software. Accept all defaults.

6. You will end up with an $\mathrm{R}$ icon on your desktop. Double-click to start the control screen.

7. In the menu bar, select "Packages" -> "Set CRAN mirror". Select a site near your location.

8. In the menu bar, select "Packages" -> "Install package(s)..." Select "Rserve" from the list.

9. Click OK to install Rserve.

10. Before each use in Tableau, do the following (there is a way to automate this):
a) Run $\mathrm{R}$ by clicking on the $\mathrm{R}$ desktop icon.
b) In the command window, enter library(Rserve) and press the Enter key. NOTE: Command is CASE SENSITIVE!
c) In the command window, enter Rserve() and press the Enter key. NOTE: Command is CASE SENSITIVE!
d) Run Tableau Desktop.
e) Click Help -> Settings and Performance -> Manage R Connection.
f) Key in localhost for the Server name and 6311 for the Port. NOTE: You might have to use 127.0.0.1 for Server name.
g) Click the "Test Connection" button to test the connection. NOTE: These four steps are a one-time process.

\subsubsection{Inputs and Key Outputs}

The Tableau desktop version of PFMT first connects to the PFMT Excel version file "Tableau Inputs" worksheet and "TableauStateInputs" worksheet to extract all the input data values. All the other inputs (technology inputs, FINModule worksheet inputs) need to be entered as parameters within the Tableau dashboard displayed as text boxes, dropdown lists, radio buttons, etc. The key outputs of this tool are generated using financial calculations within a Tableau-R interface environment, and the final deliverable is a set of interactive dashboards that allow the user to intuitively explore the impacts of different federal and state policies on the financial costs of power projects (including different technologies such as solar, wind, gas, biomass, etc.) across all the 50 states of United States. The input-parameters dashboard displays all the finance, technology and dashboard inputs that can be varied by the user (Figure 5). 
Dashboard, Technology and Finance Inputs

\begin{tabular}{|c|c|c|c|c|}
\hline Dashboard Inputs & \multicolumn{3}{|c|}{ Finance Inputs } & Technology Inputs \\
\hline Technology & Fuel Escal Rate & Debt Service Ratio & Debt Max Life & Plant Life \\
\hline 150 MW PV & 0 & 0.5 & 15 & 30 \\
\hline & & Work Capital \% & PPA Life & Book_Dep_Life \\
\hline PPA_Inp/Out & Construction Rate & 12.5 & 20 & 30 \\
\hline PPA as output & 0 & & & Capacity Factor (\%) \\
\hline State for PPA Input & Price Escal Rate & Interest Rate & Fed Income Tax Rate & 23 \\
\hline$A Z$ & 0 & 5 & 35 & O M Matl \\
\hline & Inflation Rate & Rent Coverage Ratio & ITC Applicable(\%) & 50 \\
\hline PPA Price \$/MWh & 2 & 1.109855739 & 90 & O M labor \\
\hline 11.66 & O M Escal rate & REC Price Flag & Sale Lease & 50 \\
\hline & 0 & National $\quad$ - & Yes & ITC \\
\hline & Debt_Serv_Resrve & RFC Price $\$ / M W h$ & Deht Used & 150 MW PV \\
\hline & 0.5 & 10 & ves & 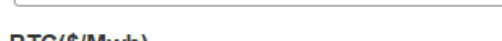 \\
\hline & & 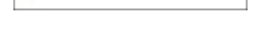 & & $\begin{array}{l}\text { PTC(\$/Mwh) } \\
150 \mathrm{MW} \text { PV/Gas CC/CT/Nuclear }\end{array}$ \\
\hline & & & & 150 MW PV/Gas CC/CT/Nuclear \\
\hline & Other Inputs & State & Inputs & $\begin{array}{llllllllll}0 & 1 & 1 & 1 & 1 & 1 & 1 & 1 & 1 & 1\end{array}<>$ \\
\hline & Allowed ROE & Property TaxMethod & & Tax Deprec Life \\
\hline & Allowed ROE & Property Iaxivethod & & (Sol,Wind,Geothermal,ded Bio) \\
\hline & 12 & Net Book & 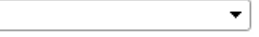 & \\
\hline & WACC & Eneray Tax & & Fuel_Cost \\
\hline & WACC & $\begin{array}{l}\text { Energy Tax } \\
0\end{array}$ & & $150 \mathrm{MW}$ PV \\
\hline & & & & \\
\hline & SelectMaplnput & Labor Tax & & \\
\hline & PPA Price Power & 0 & & \\
\hline & & State Income Tax Rate & & \\
\hline & Yearone & 6.5 & & \\
\hline & & & & \\
\hline & & $\begin{array}{l}\text { Matl Tax } \\
0\end{array}$ & & \\
\hline
\end{tabular}

Figure 5. Input Parameters Dashboard.

Table 12 below is a comprehensive list of parameters that can be modified within the Financial model through the "Parameters" sheet or the "Parameters Dashboard" sheet (where the inputs are categorized as Financial, Technology, and State inputs similar in the Excel version). 
Table 12. Tableau Input Parameters

\begin{tabular}{|c|c|c|}
\hline \multicolumn{2}{|c|}{ Numerical Parameters } & Categorical Parameters \\
\hline Book_Dep_Life & Interest Rate & Scenario Selection \\
\hline Allowed ROE & Labor Tax & State \\
\hline $\mathrm{CO}_{2}$ Cost & Matl Tax & Debt Used \\
\hline $\mathrm{CO}_{2}$ rate & O_M_Cost_MW & Technology \\
\hline Capacity Factor (\%) & O_M_Cost_Mwh & \\
\hline Capacity_MW & O_M_Escal_rate & \\
\hline Capital Energy & O_M_Labor & \\
\hline Capital Labor & O_M_Matl & \\
\hline Capital Land & LEP Price $\$ / M W h$ & \\
\hline Capital Material & PTC(\$/Mwh) & \\
\hline Capital Cost & Plant Life & \\
\hline Construction Rate & Price Escal Rate & \\
\hline Debt Max Life & Project Lifetime & \\
\hline Debt Service Ratio & PropertyTaxMethod & \\
\hline Debt_Serv_Resrve & REC Price $\$ / M W h$ & \\
\hline Energy Tax & SelectMaplnput & \\
\hline Fed Income Tax Rate & Start Year & \\
\hline Fuel Escal Rate & State Income Tax Rate & \\
\hline Fuel_Cost & State Policy(ON/OFF) & \\
\hline ITC & Tax Deprec Life & \\
\hline Inflation Rate & WACC & \\
\hline Yearone & Work Capital \% & \\
\hline LEP Life & Sale Lease & \\
\hline
\end{tabular}

\subsubsection{R Integration}

The best way to understand how the $\mathrm{R}$ integration works is to think of Tableau as the front end for displaying results obtained from a set of complex calculations that are run using $\mathrm{R}$. The flowchart below (Figure 6) gives a high-level overview of how this coupling works. 


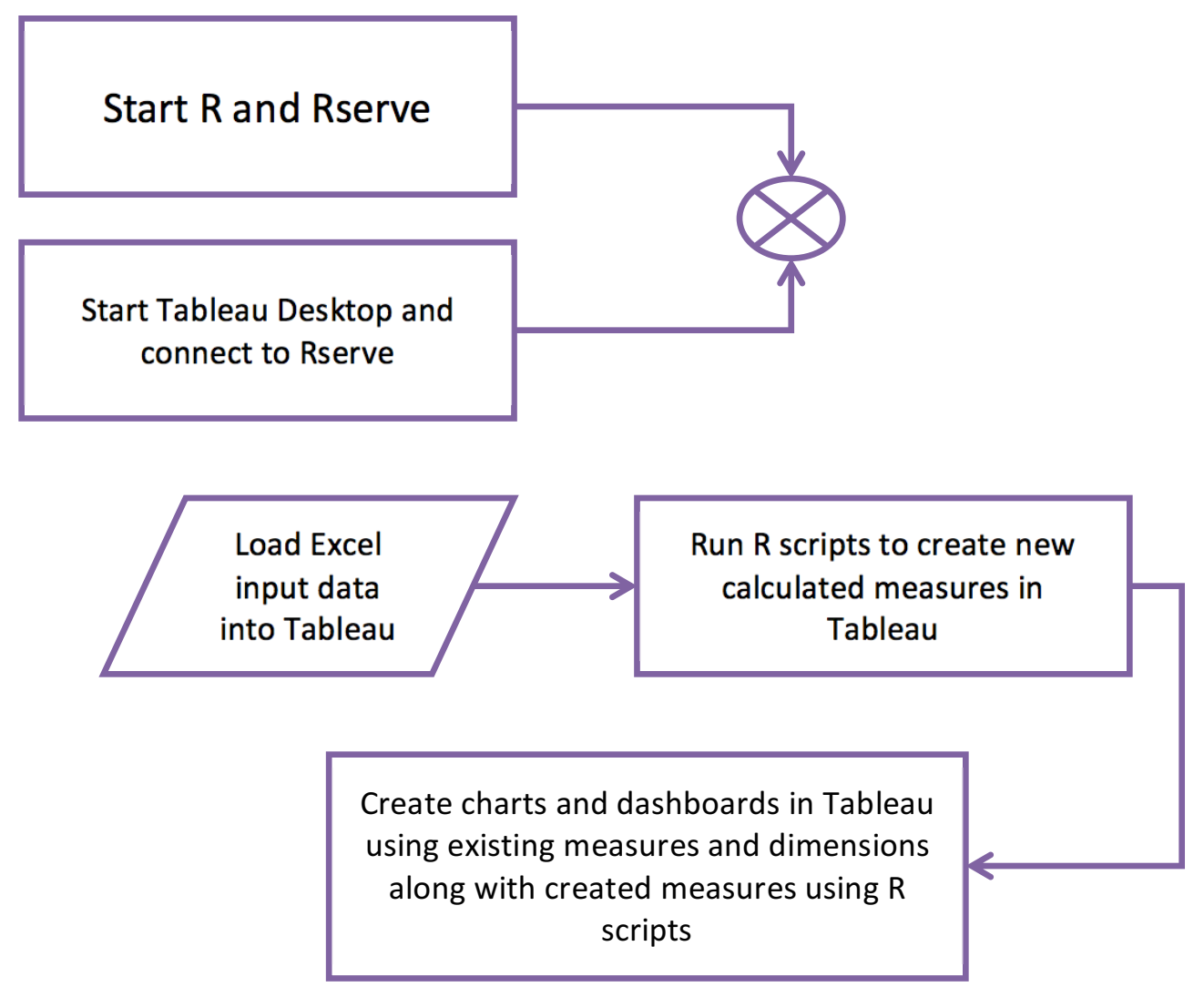

Figure 6. Flowchart describing Tableau and R coupling.

All the financial calculations that are generated as calculated fields run within the "SCRIPT_REAL" in-built Tableau function which essentially hands off the computations to an Rserver. All the input arguments required for each of these calculations are appended at the end of this "SCRIPT_REAL" function, and these values are consumed by the $\mathrm{R}$ variables at the beginning of the $\mathrm{R}$ code as shown in the sample below. For this example, there are five input parameters: [Plant Life], SUM ([Capital Cost],[Capacity_MW],[Start Year],[WACC ]). These parameters are being sent to R along with the code.

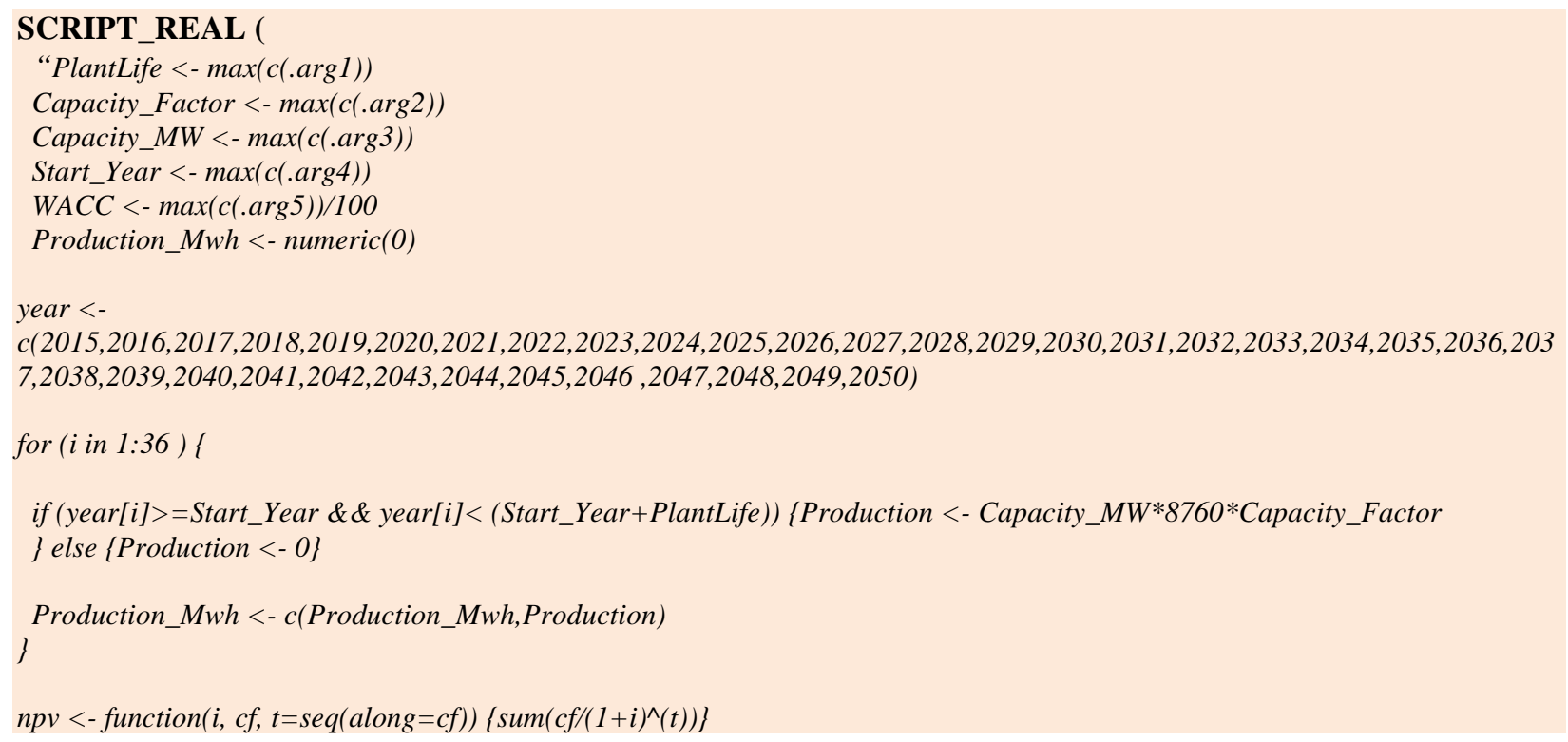


$n p v \_p r o d<-n p v($ WACC,Production_Mwh $) *(1+W A C C)$

npv_prod",[Plant Life],SUM([Capital Cost ],Capacity_MW],[Start Year],[WACC ])

Any of the calculated fields can be accessed from the Measures panel by right clicking on a field name and selecting the "Edit" option (Figure 7).

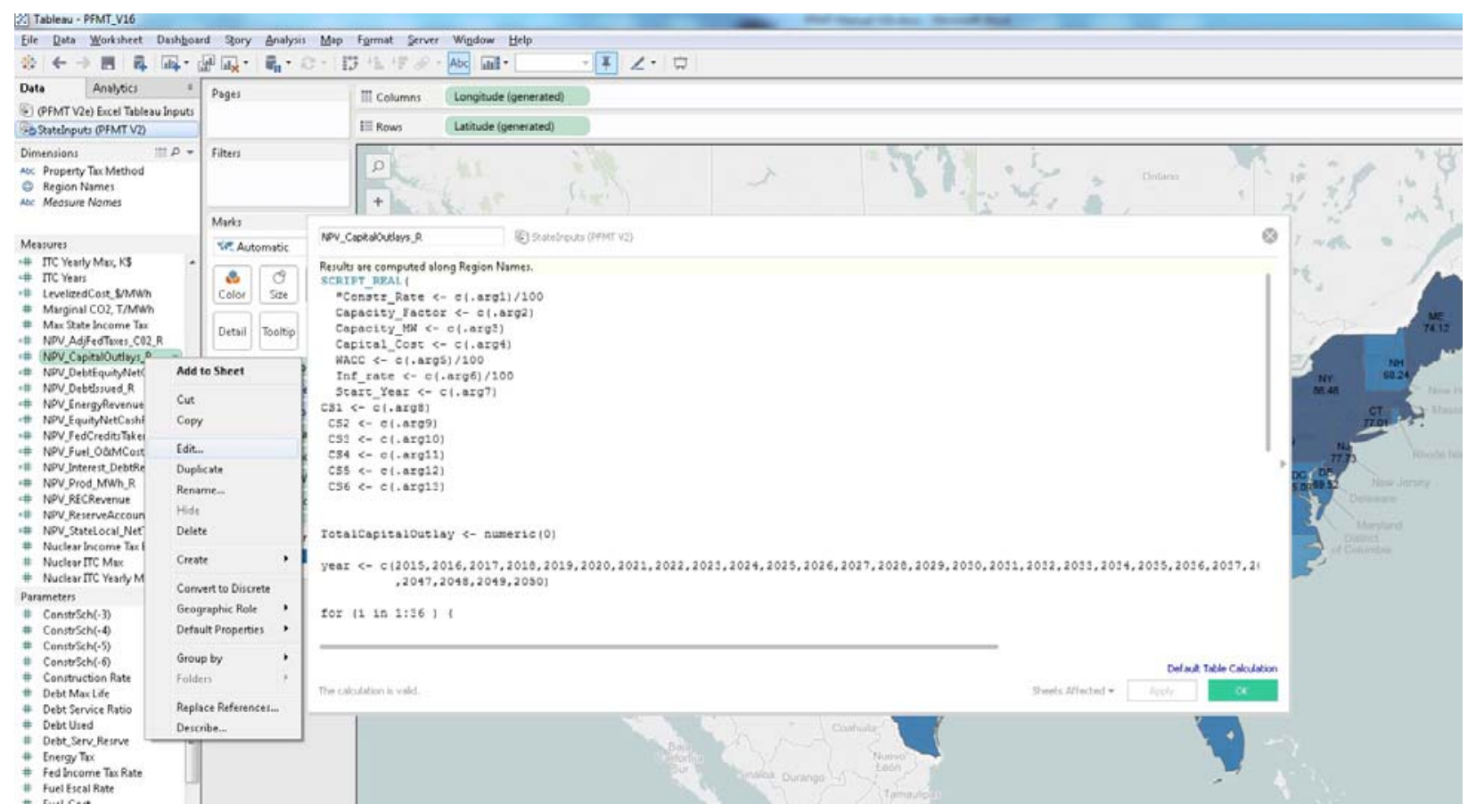

Figure 7. Accessing calculated fields and their underlying $\mathbf{R}$ codes.

\subsubsection{Dashboard Outputs}

The following measures (Table 13) are calculated and displayed as a table within the "Dashboard Outputs" sheet. Each of these calculations comprise individual R scripts with about 50 parameter input values, and they generate a single output value for each state. Since these calculations are being run across the entire nation, the Table Calculations option must be set to compute "using Cell" because this option sets the addressing to the individual cells in the imported data table from Excel. All fields become partitioning fields.

Table 13. R Script Names for Dashboard Outputs

\begin{tabular}{|l|l|}
\hline Display Names & Measure Names \\
\hline Estimated LEP & LEP in R \\
\hline Return on Equity & Return_On_Equity_R \\
\hline Return on (D+E)/IRR & IRR_DebtEquity_R \\
\hline Return for Lessor & Return_On_Lessor_R \\
\hline Return for Lessee & Return_On_Lessee_R \\
\hline
\end{tabular}

\subsubsection{Net Cash Flow Calculations}

Revenue, Capital Costs, Operating Costs, Debt Costs and Net Taxes are calculated separately as R measures within "SCRIPT_REAL" built--n Tableau function. These measures are used to create a 
Tableau sheet named "NetCashFlowInteractive". This visualization graph can be filtered using the "Region Names". Hence, multiple cash flow diagrams for several states can be visualized simultaneously for comparison purposes.

Note: Each of these R measures was independently tested within the $R$ environment (with input parameters hardcoded) and was then tested within the Tableau Desktop by varying input parameters on the front end interface to match the Excel version of the PFMT model output.

\subsubsection{Net Present Value (NPV) Calculations}

The following measures are calculated and displayed as a table within the "NPV Outputs" sheet (Table 14). Each of these calculations comprises individual $R$ scripts, and each calculation takes approximately 50 parameter input values and generates a single output value for each state. Since these calculations are run across the entire nation, the Table Calculations are set to compute "using Cell" option as this sets the addressing to the individual cells in the imported data table from Excel. All fields become partitioning fields.

Table 14. R Script Names for NPV Outputs

\begin{tabular}{|l|l|}
\hline Display Names & Measure Names \\
\hline Adj Fed Taxes & NPV_AdjFedTaxes_C02 \\
\hline Capital Outlays & NPV_CapitalOutlays \\
\hline Net Cash Flow(D+E) & NPV_DebtEquityNetCashFlow \\
\hline Debt Issued & NPV_DebtIssued \\
\hline Energy Revenue & NPV_EnergyRevenue \\
\hline Net Cash Flow(Equity) & NPV_EquityNetCashFlow \\
\hline Fed ITC+PTC & NPV_FedCreditsTaken \\
\hline Fuel + O\&M Costs & NPV_Fuel_O\&MCosts \\
\hline Interest + Debt Repaid & NPV_Interest_DebtRepaid \\
\hline REC Revenue & NPV_RECRevenue \\
\hline Reserve Account & NPV_ReserveAccount \\
\hline State/Local NetTax & NPV_StateLocal_NetTax.R \\
\hline
\end{tabular}

Note: Each of these R measures was independently tested within the R environment (with input parameters hardcoded) and was then tested within the Tableau Desktop by varying inputs parameters on the front end interface to match the excel version of the PFMT model output.

\subsubsection{Tableau Desktop Workbook Features}

- The tableau desktop solution enables the accessibility to the PFMT Tableau workbooks using installation of the standalone Tableau Desktop license. The workbooks accessed through the desktop are fully interactive and will need to connect to a local R server so that the financial calculations are performed on the fly.

- The workbooks that are currently accessible from the Tableau Desktop are not pre-computed. Hence, the visualizations of the model results in response to user-inputs take a while (about 5 to 6 seconds) to update since the software is directly interfacing with the $\mathrm{R}$ environment to perform the computations instantaneously.

- This workbook version exposes the complete capability of the tool, and hence it is ideal for financial analysts and domain experts (e.g., EPSA analysts) who are cognizant about the various financial, policy, and technology parameters existing in the model and who can study their impacts on the energy project financial viability in a systematic fashion. 


\subsubsection{Tableau Desktop Dashboard Design}

Each dashboard view is connected to one or more worksheets that it represents. Therefore, when the user makes changes to the worksheet, the dashboard is automatically updated. Conversely, changes the user makes to the dashboard affect the worksheet. Therefore, the user can edit the original view by jumping to a selected worksheet from a dashboard.

Below is the list of Tableau sheets created within Tableau Desktop which can be combined in any desired fashion to create dashboards:

- LEP Output Map

- NetCashFlowInteractive

- Dashboard Outputs

- NPV Outputs

- StateData-DSIRE Database

- National Summary

- TreeMap

\subsubsection{Tableau Dashboards Created Within Tableau Desktop}

Tableau dashboards created within Tableau Desktop differ from those created within the pre-computed workbooks with some additional parameters added to allow for more flexibility in configuration. Because there are about 35 parameters that are configurable, analysts can add them dynamically into the dashboard by accessing Analysis $\rightarrow$ Parameters from the menu.

Figure 8 displays the Estimated LEP for the desired ROE level on a map and Net Cash Flows for the selected states on the map also allowing simultaneous display of multiple cash flow charts. All the input parameters which the user can vary (Allowed ROE, Technology, WACC, REC Price Flag, REC Price, SelectMapInput, PTC, ITC for all technologies, etc.) are displayed on the left, and the dashboard's outputs [LEP, IRR(Debt+Equity, Return for Lessor, Lessee, etc.] are displayed on the right. 


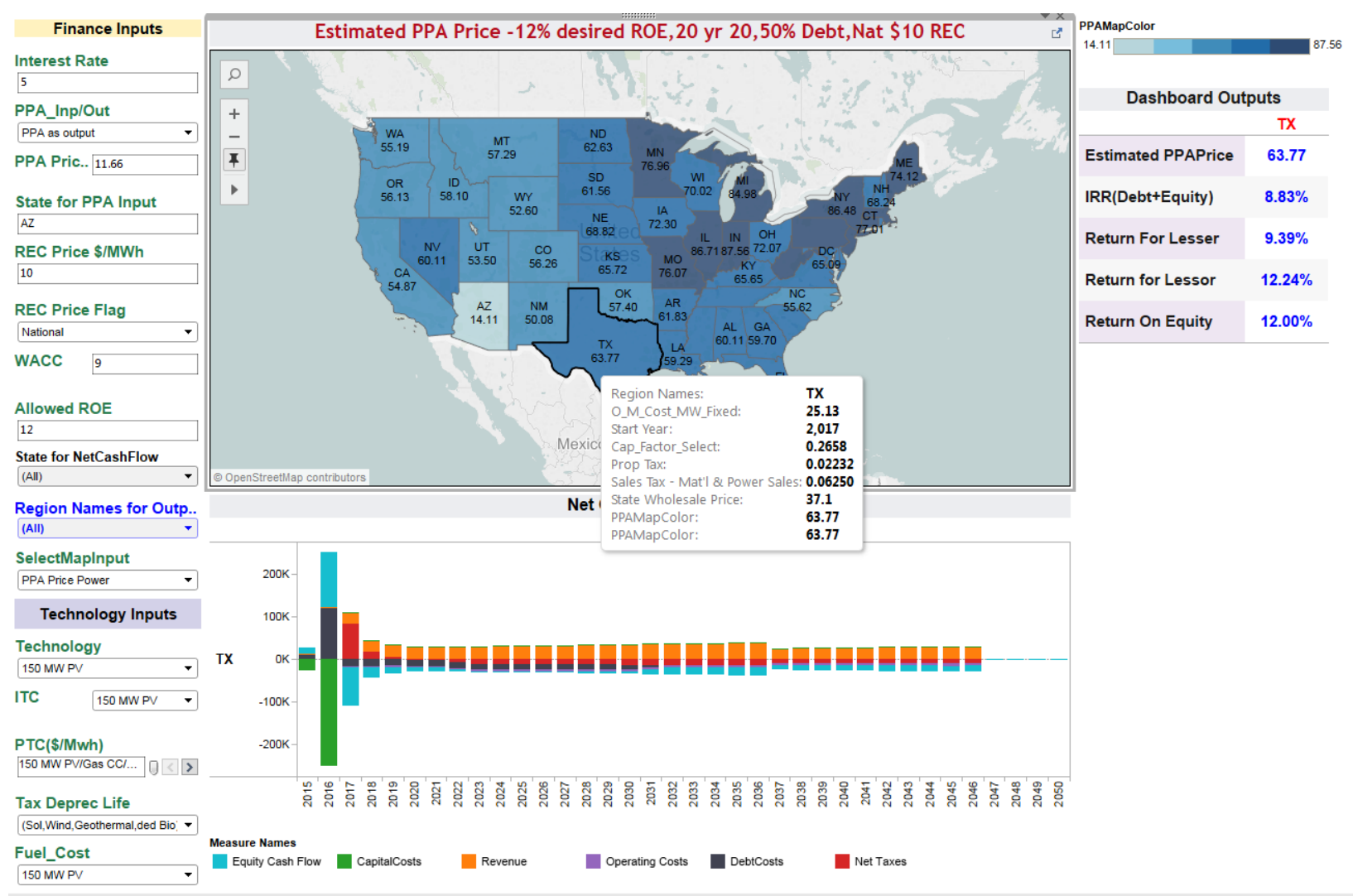

Figure 8. LEP Map Dashboard for 150 MW PV Technology with Tableau Desktop. 
Figure 9 displays the Net Cash Flow diagram of selected states for a selected Technology allowing simultaneous display of multiple cash flow charts. All the input parameters, which the user can vary (Allowed ROE, Technology, WACC, Fed Income Tax Rate, REC Price Flag, REC Price, SelectMapInput, PTC, ITC for all technologies, etc.), are displayed on the left, and the dashboard outputs (LEP, IRR-Debt+Equity, Return for Lessor, Lessee, etc.) are displayed on the right.

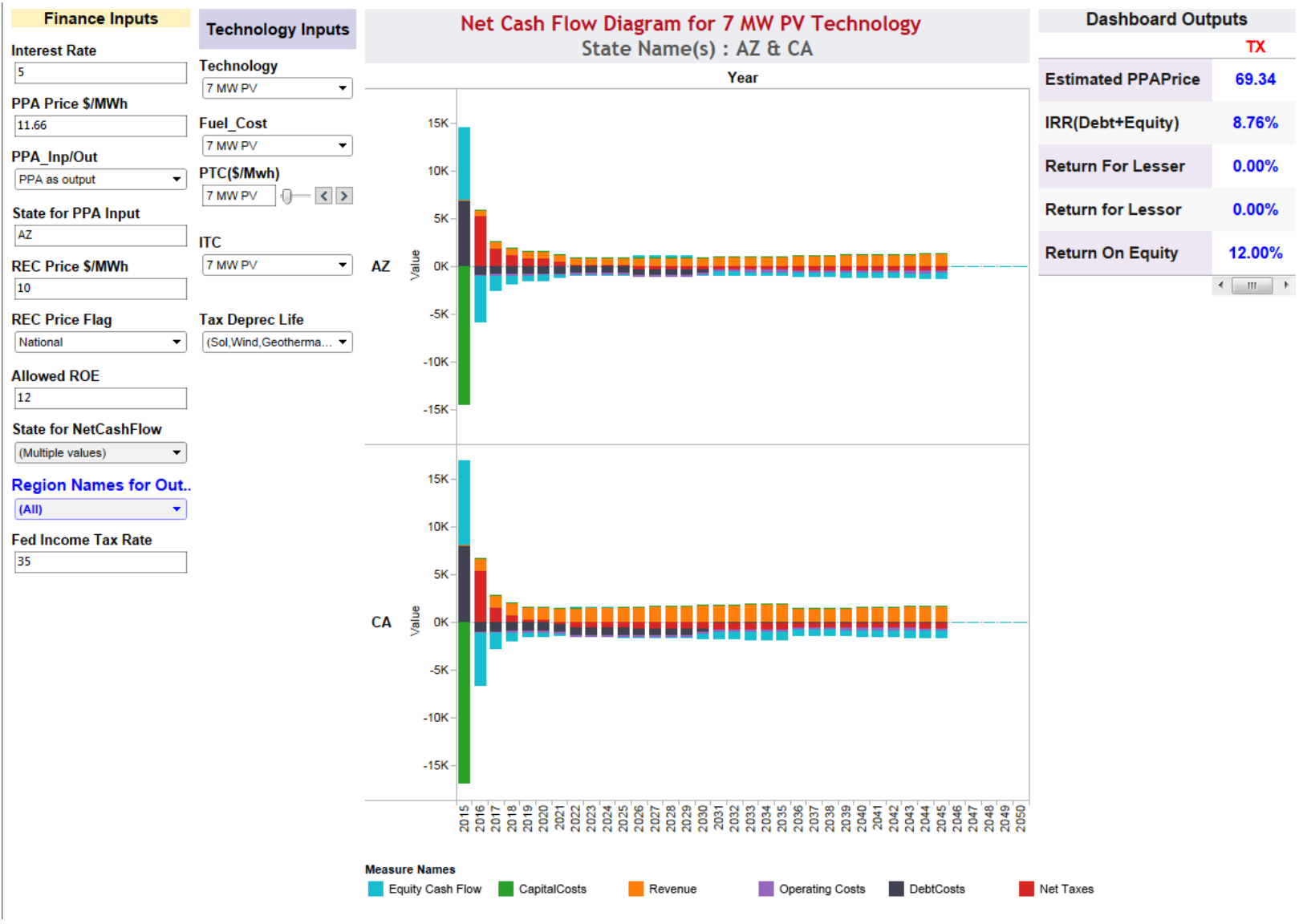

Figure 9. Net Cash Flow Dashboard for 7 MW PV Technology within Tableau Desktop. 
Figure 10 shows the LEP Map dashboard view for Small PV technology with 12\% desired ROE and 5\% interest rate as inputs.

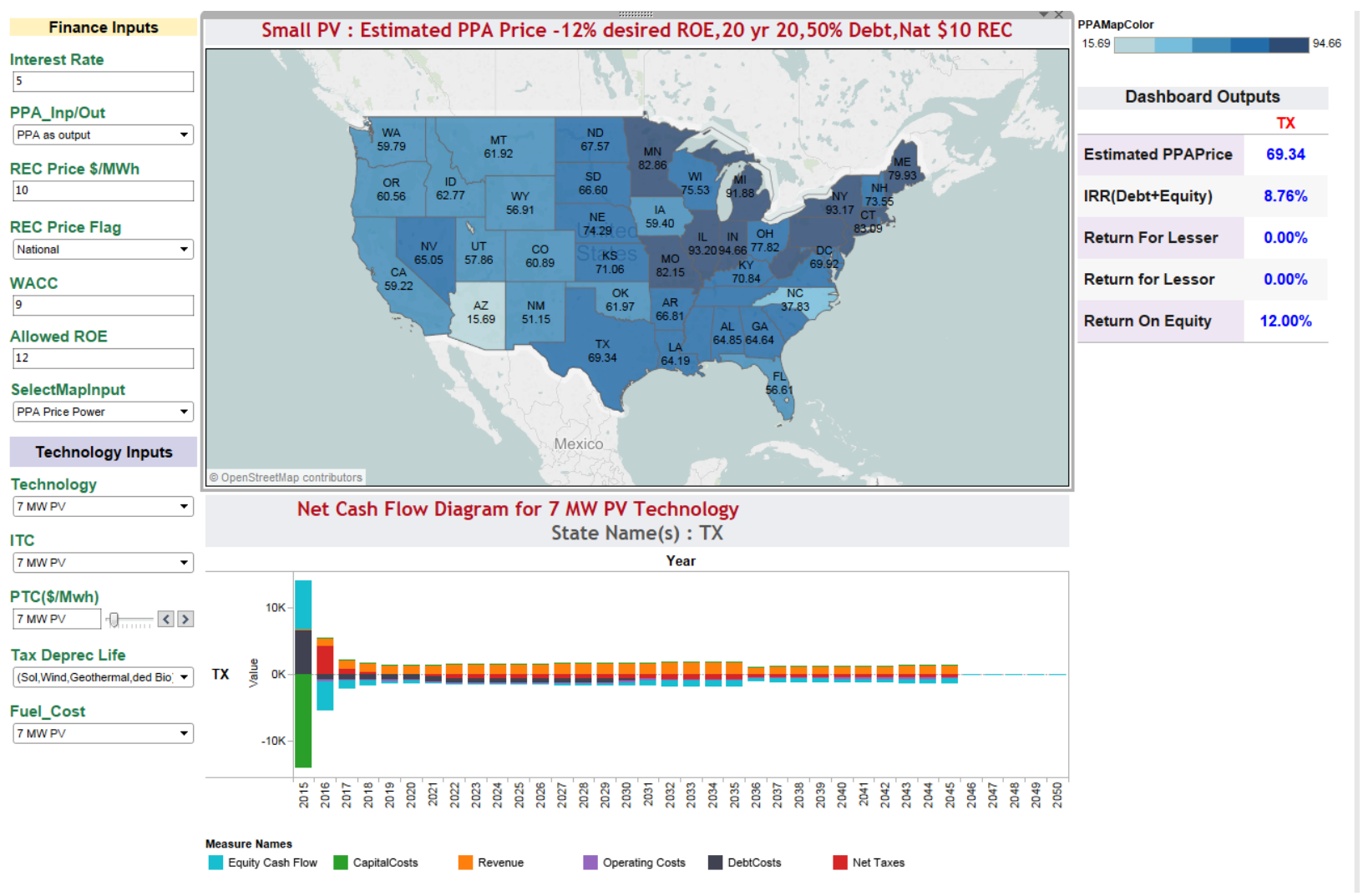

Figure 10. LEP Map Dashboard for 7 MW PV Technology within Tableau Desktop. 
Figure 11 displays a scatterplot of the calculated LEP versus the state's input wholesale price for all the 50 states.

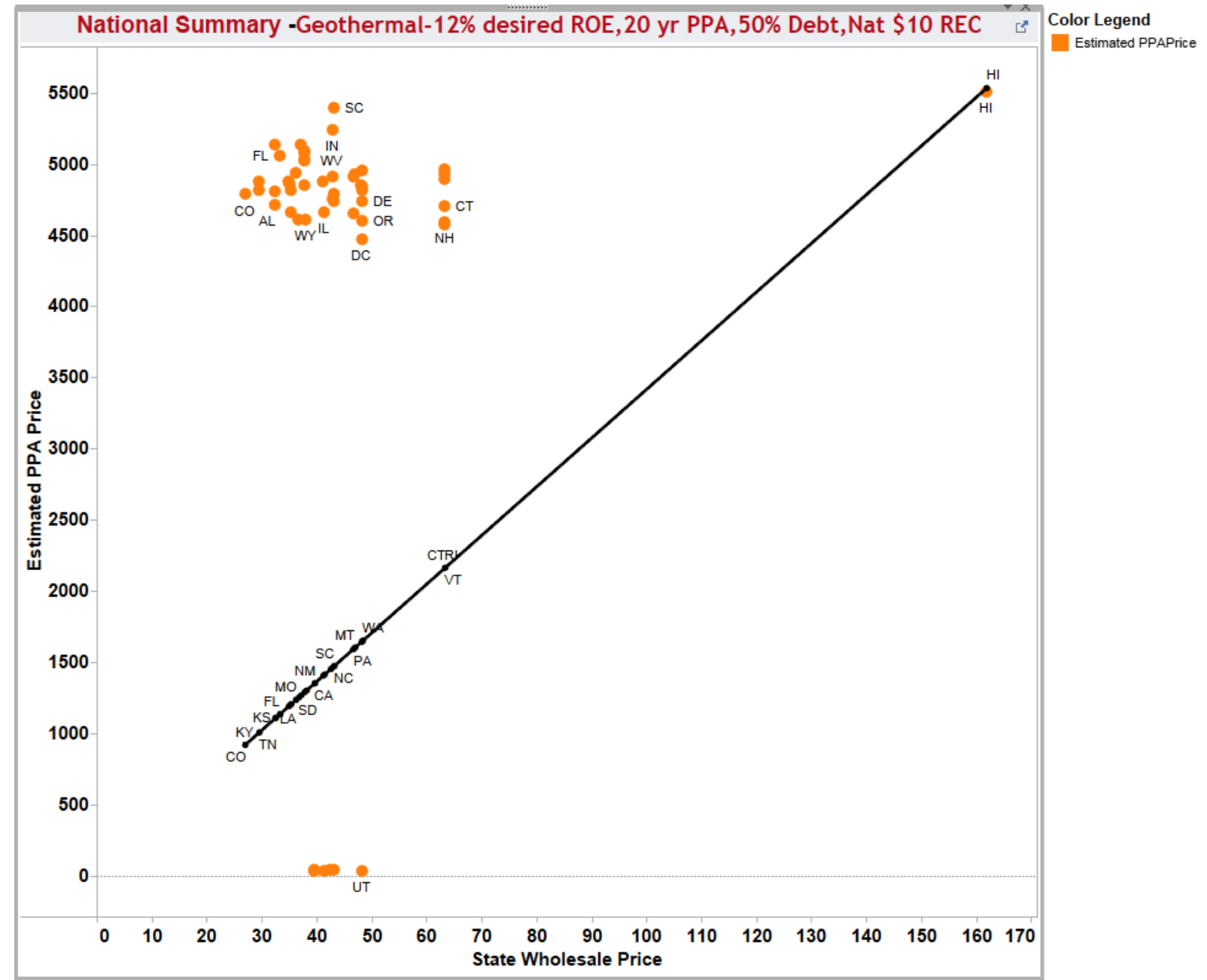

Figure 11. National Summary Dashboard for Geothermal Technology within Tableau Desktop. 
Figure 12 displays two maps indicating the relationship between the state exemptions and the calculated LEP versus the state's input wholesale price for all the 50 states.
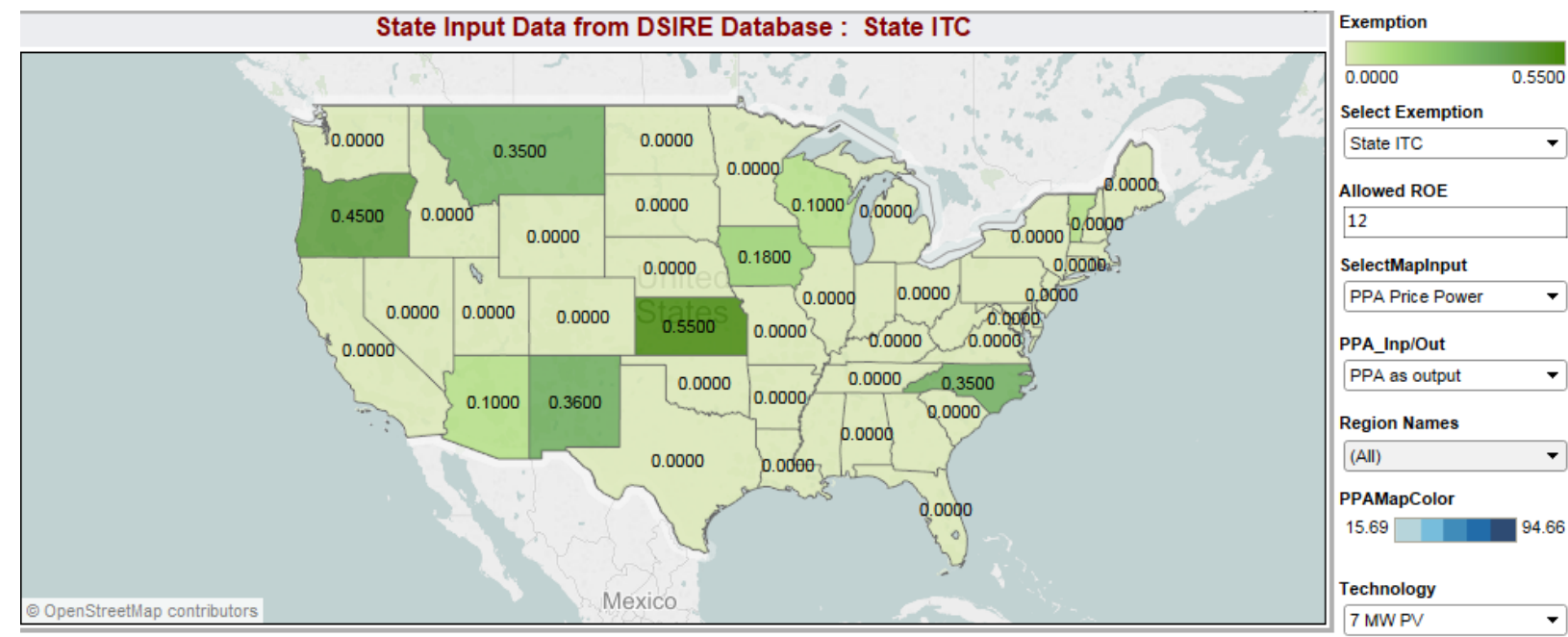

Small PV : Estimated PPA Price $-12 \%$ desired ROE, 20 yr 20,50\% Debt, Nat \$10 REC
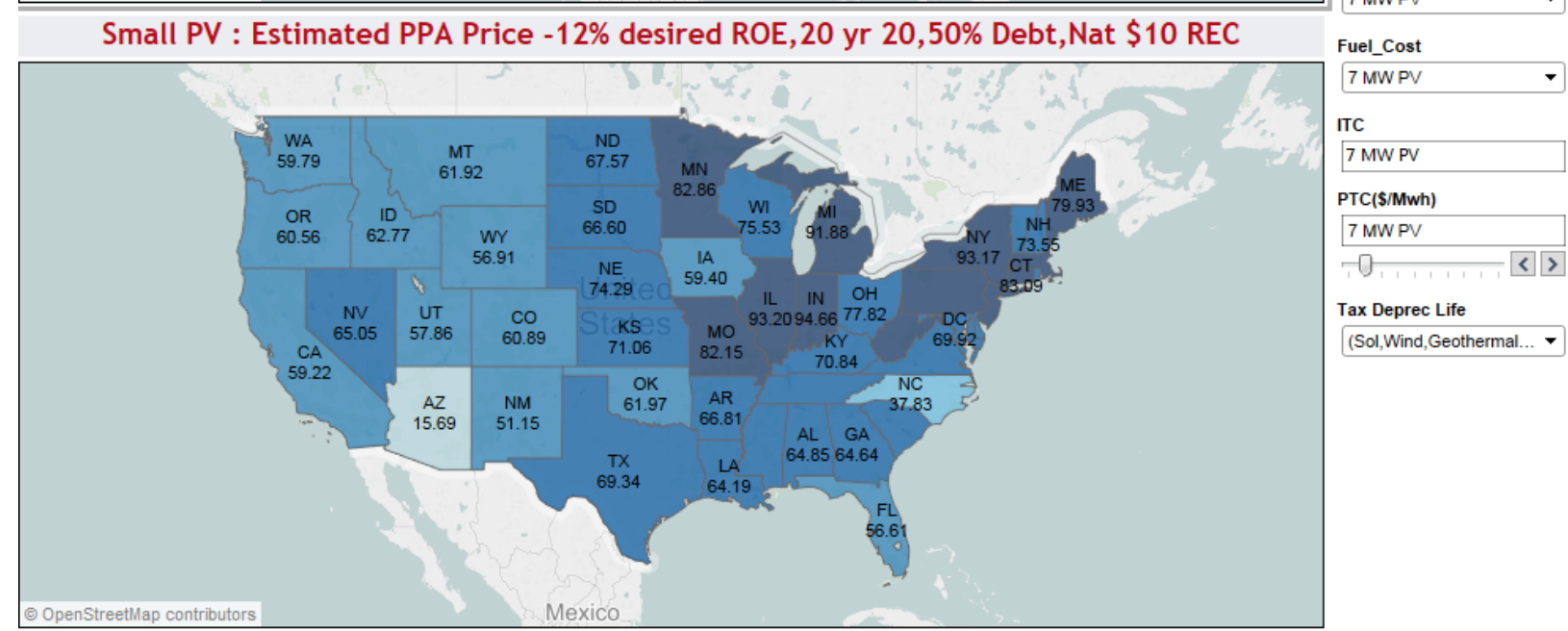

ITC

7 MW PV

PTC(\$/Mwh)

7 MWPV

Tax Deprec Life

(Sol,Wind,Geothermal... .

Figure 12. StateData-DSIRE+ LEP Map Dashboard within Tableau Desktop.

\subsection{TABLEAU SERVER SOLUTION}

\subsubsection{Tableau Server 9 Installation}

Tableau Server (version 9.0.5 9000.15.0820.1222 64-bit) is currently installed on an ORNL Windows server machine. This production environment is a virtual machine that has two processors with four physical cores each. This is an externally facing virtual machine running Windows server 2012, which is accessible from any web browser (e.g., Internet Explorer, Firefox) using user credentials.

\subsubsection{Tableau Server Workbook Features}

- The Tableau Server enables the accessibility to the PFMT Tableau workbooks using internet and any web browser from any location. The workbooks accessed through the server are fully 
interactive and require no additional software installations for the PFMT operation. Hence, the server allows broader usage and is not just restricted to the DOE_EPSA analysts.

- The workbooks that are currently accessible from the Tableau server are pre-computed scenarios. Hence, the visualization of the results of the model in response to user inputs is extremely fast since we are not directly interfacing with the R environment to do the calculations on the fly, thereby saving the computation time.

- Although this workbook version does not expose the complete capability of the tool, it is ideal for decision makers who are not hardcore financial analysts because it facilitates identification of key insights and enables easy understanding of the results with a fairly simple and intuitive user interface.

\subsubsection{Tableau Server Workbook Scenario Details}

For the Map Dashboard, the following scenarios were computed:

1) Four Technologies - $150 \mathrm{MW}$, Onshore Wind, GasCC, and Gas CT

2) Interest Rate $-5 \%$ and $7 \%$

3) Allowed ROE $-8 \%$ and $12 \%$

4) Fed Income Tax Rate $-0 \%$ and $35 \%$

5) ITC $-0,10,20,30 \%$ (Only for $150 \mathrm{MW}$ Technology with Fed IT $=35 \%$ fixed, Allowed ROE $=8 \%$ fixed, $\mathrm{PTC}=0$ fixed, InterestRate $=5 \%$ fixed $)$

6) PTC - 0 and 22 (Only for Onshore Wind Technology but all combinations of ROE, Fed IT, and Interest Rate)

For the NetCashFlow Dashboard, the following scenarios were computed:

Interest Rate $-5 \%$ fixed.

1) Four Technologies - $150 \mathrm{MW}$, Onshore Wind, GasCC, and Gas CT

2) Allowed ROE - 8\% and $12 \%$

3) Fed Income Tax Rate $-0 \%$ and $35 \%$

4) ITC $-0,10,20,30 \%$ (Only for $150 \mathrm{MW}$ Technology with Fed IT $=35 \%$ fixed)

5) PTC - 0 and 22 (Only for Onshore Wind Technology but all combinations of ROE and Fed IT)

For Geothermal, Biomass, Offshore Wind, Building PV, two scenarios for each were computed based on the default technology inputs from PFMT_V2j.xlsm version (With interest rate 5\% fixed, Fed Income tax rate $35 \%$ fixed, and ROE $8 \%$ and $12 \%$ ).

\subsection{TABLEAU STORY POINTS FOR ILLUSTRATION}

Story Points is a way to create a narrative with data. You can tell a story with data, just as you can tell a story with pictures. For illustration purposes, two story points were created (Figure 13 and Figure 14) within the workbook (Tab color Red) showing PTC sensitivity analysis for onshore wind and sensitivity analysis of ITC for large PV technology. 


\section{OnShore Wind-Sensitivity to PTC Changes}

Allowed ROE

$8 \%$

(-) $12 \%$

Fed Income Tax Rate

$0 \%$

- $35 \%$

Interest Rate

$5 \%$

ITC for Solar

$30 \%$

PTC(\$/MWh) for Wind

Technology

O 150 MW PV

- Onshore Wind(100 MW)

Gas CC(400 MW)

Gas CT(210 MW)

Geothermal (50 MW)

Biomass(150 MW)

Small PV (7 MW)

Offshore Wind(400 MW)

Region Names

All

Select PPA Price

PPA_FLAG

PPA_noREC

AZ

$$
\begin{array}{ll}
\text { OnShore Wind PTC }=0 & \begin{array}{l}
\text { OnShore Wind } \\
\text { Allowed } \mathrm{ROE}=12
\end{array} \\
\mathrm{PTC}=22 \\
\text { Allowed } \mathrm{ROE}=12
\end{array}
$$

Estimated PPA Price $-12 \%$ desired ROE, 20 yr PPA,50\% Debt, Nat \$10 REC

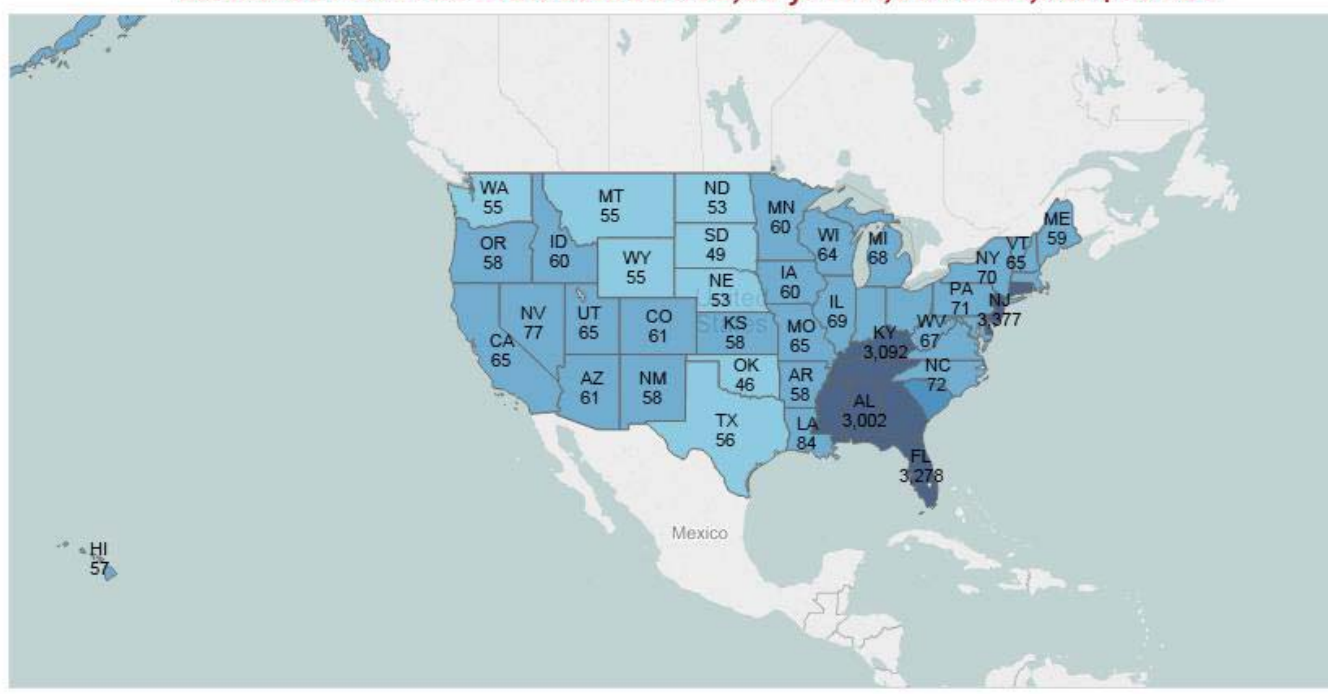

Net Cash Flow Diagram for Onshore Wind(100 MW) Technology

State Name(s) : AZ \& CA

Fixed Parameters : Interest Rate :5\%

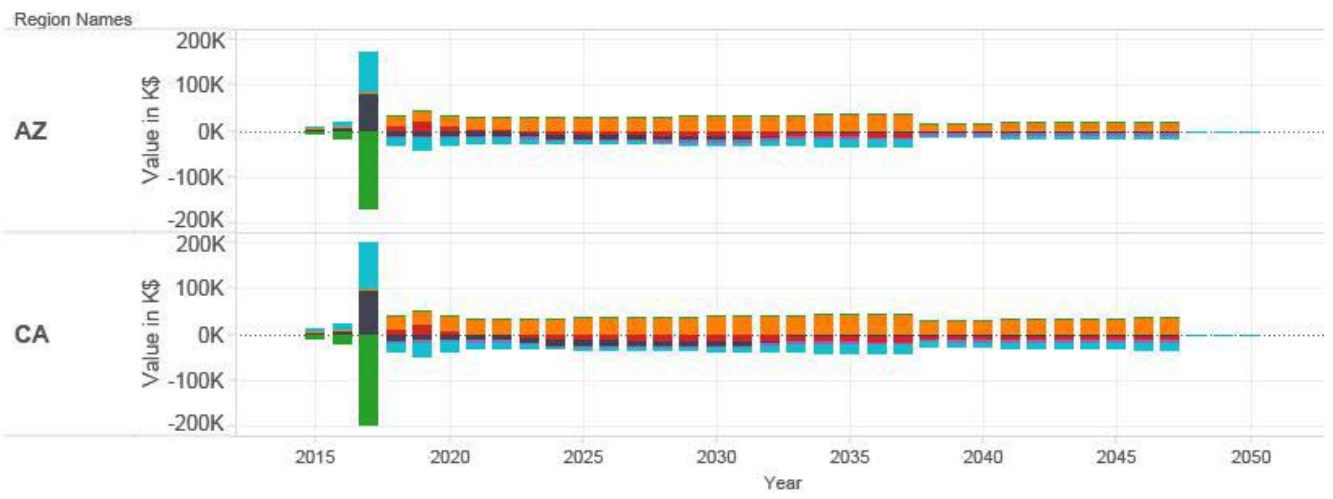

Figure 13. Story Points Describing Sensitivity to PTC Changes for Onshore Wind Technology. 


\section{Sensitivity Analysis due to ITC Changes}

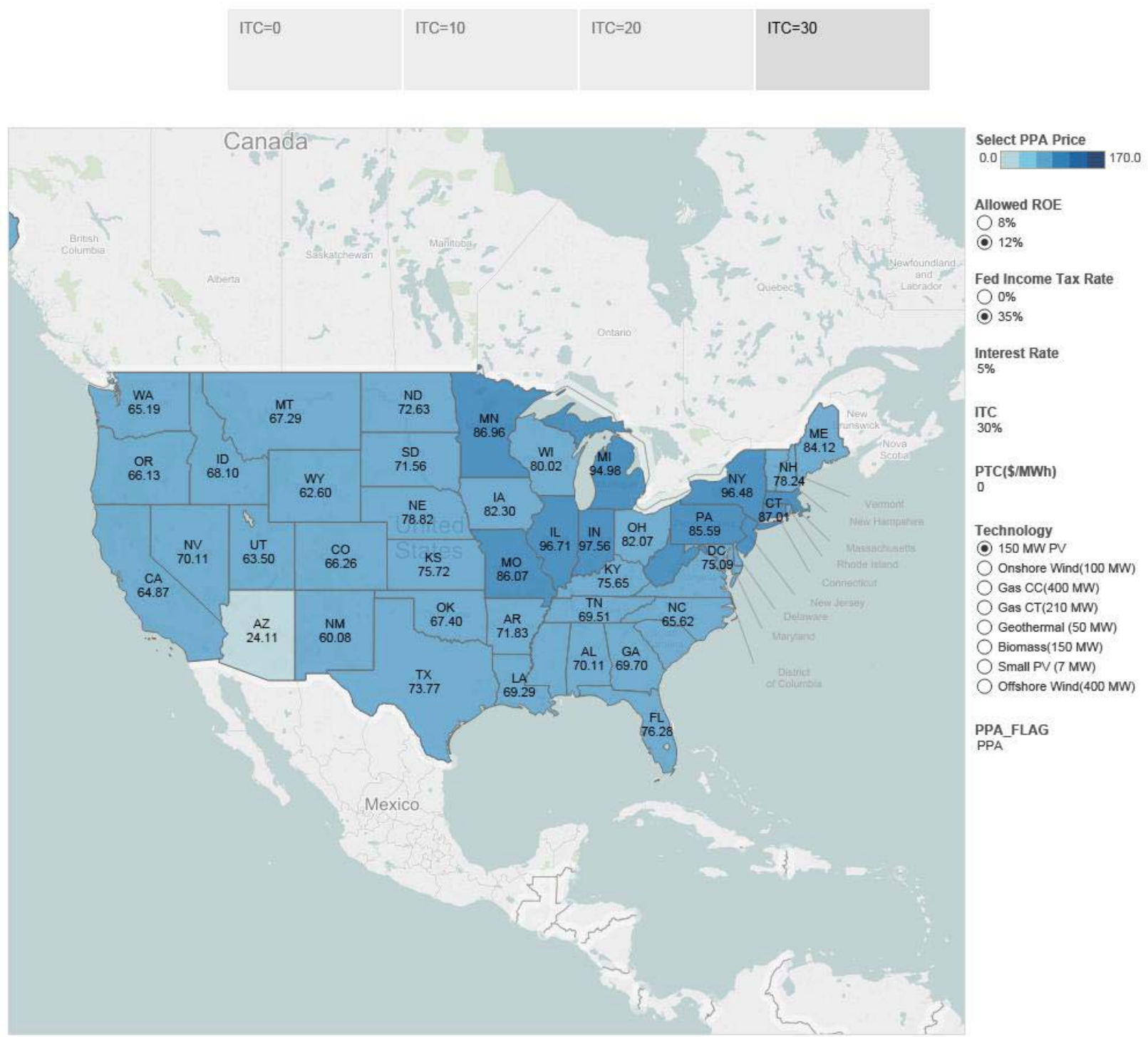

Figure 14. Story Points Describing Sensitivity to ITC Changes for Large PV Technology.

\subsubsection{Tableau Dashboards Published On Tableau Server}

Below is the list of worksheets created within the pre-computed workbook that were used to create various dashboards.

- Estimated LEP Output Map

- ITC Selection

- NetCashFlow

- Dashboard Outputs

- Technology-inputs

Figure 15 displays a dashboard consisting of the NetCashFlow and Technology inputs worksheet that allows simultaneous display of multiple cash flow charts for the selected states within the Region Names 
dropdown menu. All the input parameters, which the user can vary (Allowed ROE, Technology, PTC for Wind, ITC for solar, etc.), are displayed on the left, and the dashboards outputs (LEP, IRR (Debt+Equity) are displayed on the right.

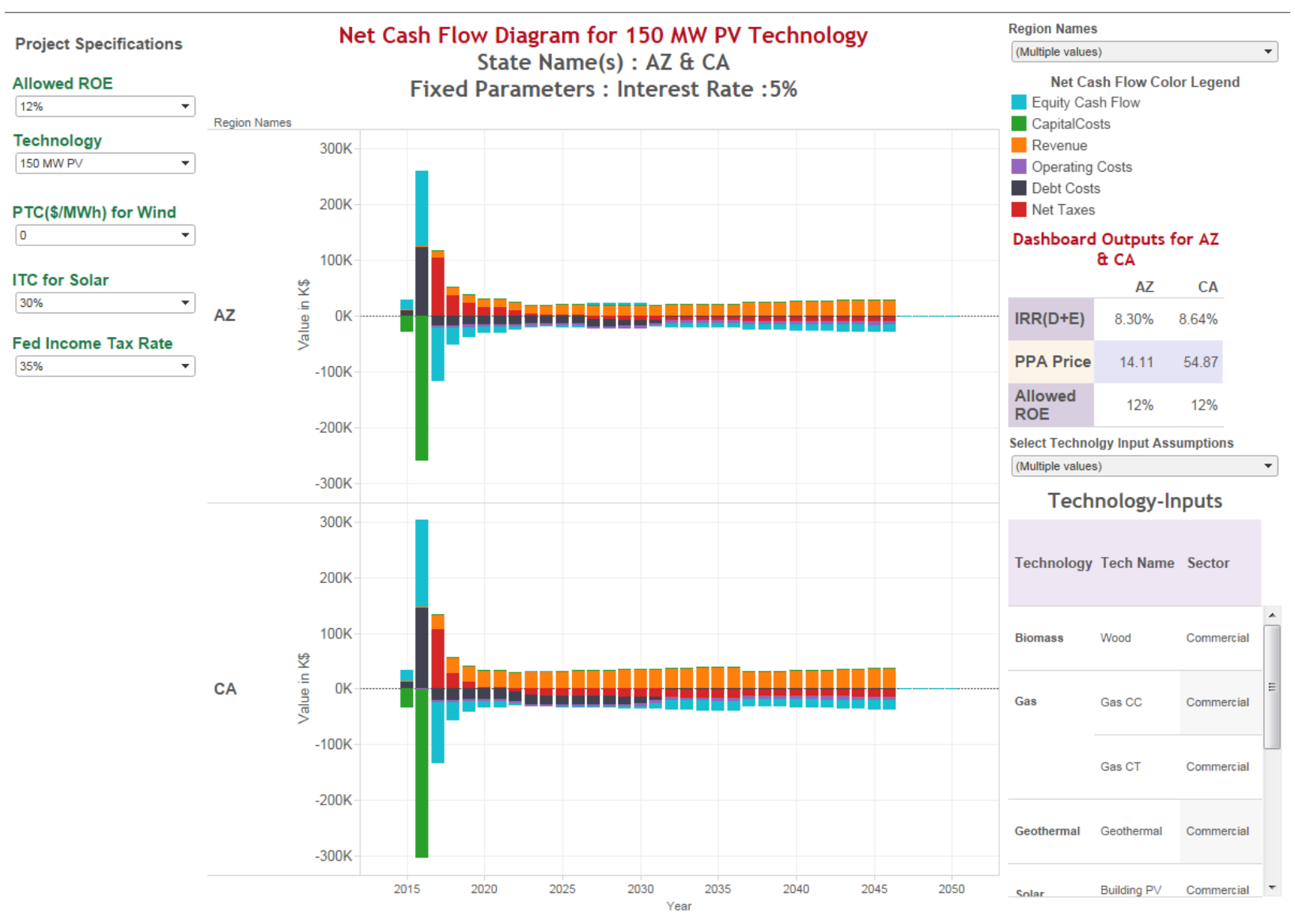

Figure 15. Net Cash Flow Diagram for 150 MW PV Technology.

The Figure 16 dashboard consists of the Estimated LEP Output Map worksheet that provides a national perspective of the LEPs estimated such that the return on equity matches a desired input level. All the input parameters, which the user can vary (Allowed ROE, Technology, PTC for Wind, ITC for solar, etc.), are displayed on the left, and the dashboard's outputs (LEP, IRR (Debt+Equity) are displayed on the right. Various input data sources used for all the technology, financial, and policy inputs can also be accessed within the same dashboard. 


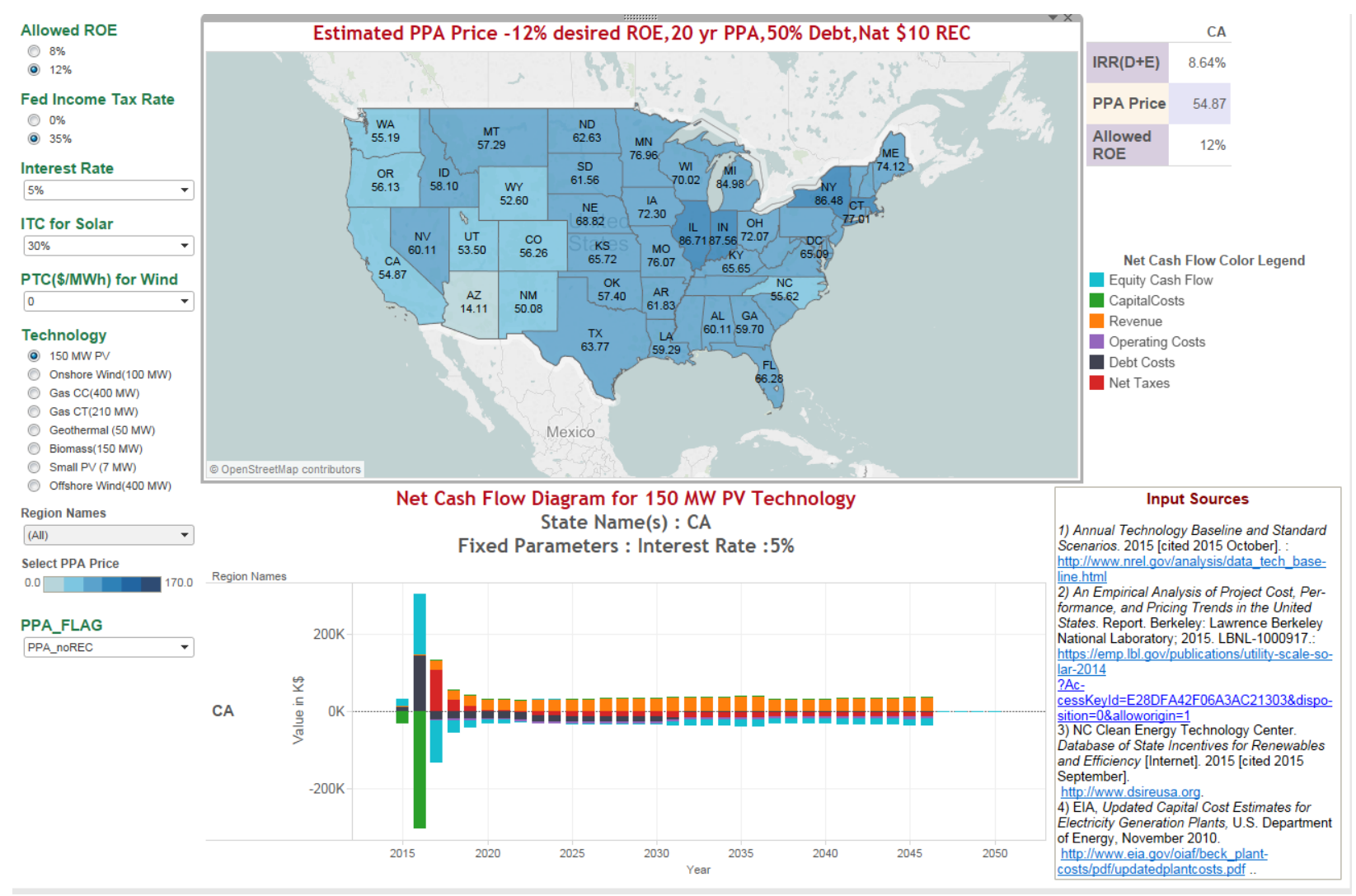

Figure 16. LEP Map Dashboard for 150 MW PV Technology.

The Technology-Inputs dashboard lists the same input data as in the TechnologyInputs worksheet in the Excel version (Table 10), although reformatted for use by Tableau. Figure 17 shows LEP Map dashboard view for Geothermal technology with $12 \%$ desired ROE and $5 \%$ interest rate as inputs. 


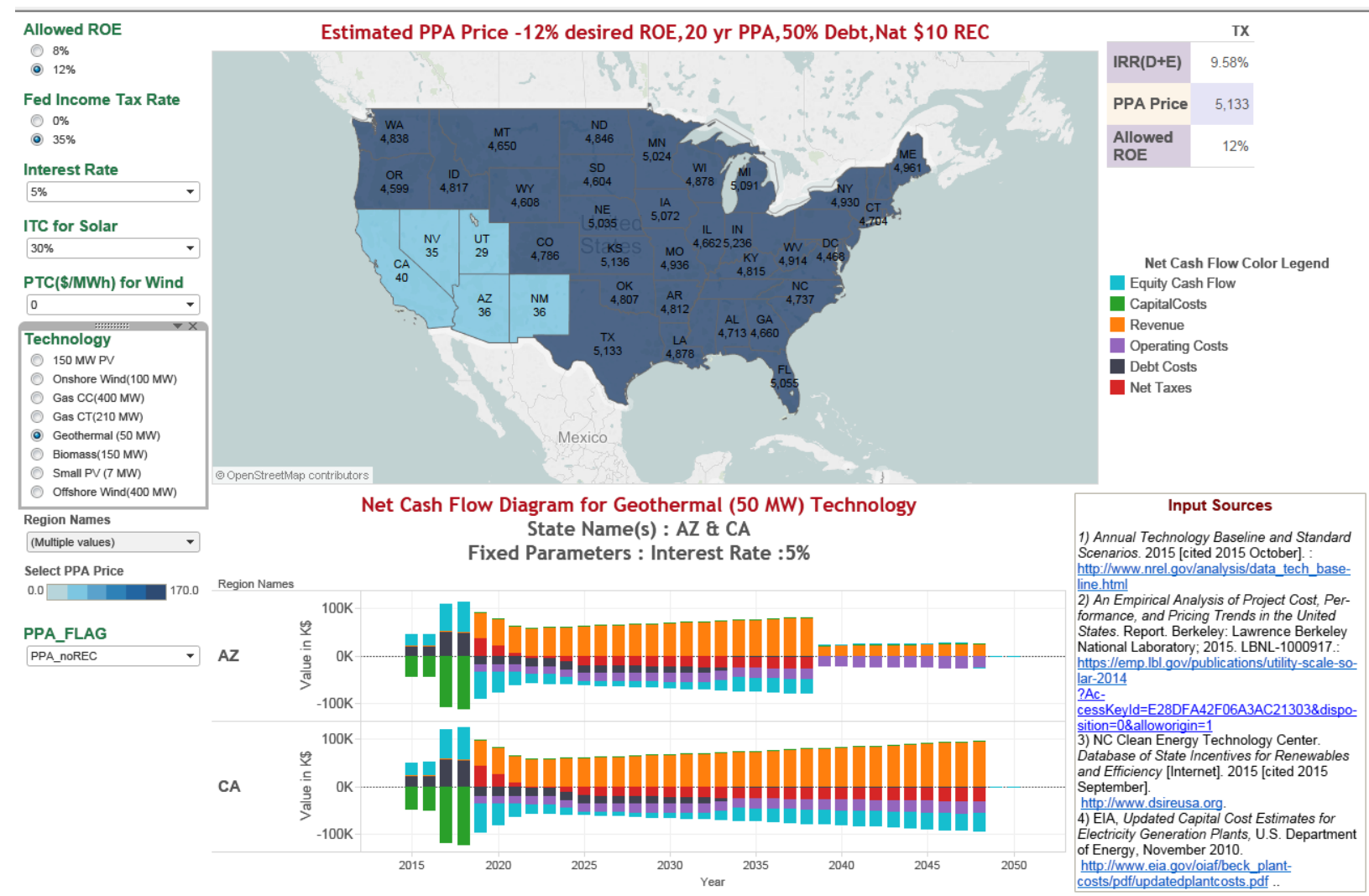

Figure 17. LEP Map Dashboard for Geothermal Technology.

\subsection{Multi-Case Sensitivity Analysis Visualization}

Analysts may wish to evaluate the impact of changing various key inputs over a range of values on multiple technologies. This is done on the MultiCase worksheet of the Excel model [refer to Section 5.3]. Results are automatically copied into the "Sensitivity Analysis" working after running various scenarios in the MultiCase worksheet.

The "SensitivityAnalysis_Dashboad.xlsx" workbook is an input file to the Tableau pre-computed workbook, namely "PrecomputedDashboards_Vxx.twbx".

NOTE: Whenever we generate new scenarios, the result values need to be appended into the "SensitivityAnalysis of the Excel model, and the data source needs to be refreshed within the "PrecomputedDashboards_Vxx.twbx" workbook.

\subsubsection{ITC Sensitivity Analysis}

Four tableau worksheets (ITCMap1, ITCMap2, ITCMap3, ITCMap4) were created to map the LEP-System prices on two United States tiled maps for two different ITC values (0 and 30\%) using an ordinal color scale. The D6-ITCMaps Dashboard combines all four worksheets to allow comparison of the LEP-System Prices across four technologies (Figure 18). Each worksheet allows selection of one of the eight technologies that are currently being modelled. Therefore, the D6-ITCMaps Dashboard allows selection of four different technologies using TechInput 1, TechInput 2, TechInput 3 and TechInput 4 dropdown menus. Details of some of the Tableau variables are given below: 


\section{LEP_System}

IF [LEP_System] $<=-50$ THEN " $<=-50 "$

ELSEIF [LEP_System] $>-50$ AND [LEP_System] $<=-10$ THEN " $>-50$ and $<=-10 "$

ELSEIF [LEP_System] $>-10$ AND [LEP_System] $<=10$ THEN ">-10 and $<=10 "$

ELSEIF [LEP_System] $>10$ AND [LEP_System] $<=50$ THEN " $>10$ and $<=50 "$

ELSEIF [LEP_System] $>50$ AND [LEP_System] $<=90$ THEN " $>50$ and $<=90 "$

ELSEIF [LEP_System] $>90$ AND [LEP_System] $<=100$ THEN ">90 and $<=1000 "$

ELSE "NA"

END

\section{System Price}

CASE [Technology Selection 1] WHEN 0 THEN [Large PV System Price]

WHEN 1 THEN [Onshore Wind System Price]

WHEN 2 THEN [Gas CC System Price]

WHEN 3 THEN [Gas CT System Price]

WHEN 4 THEN [Geothermal System Price]

WHEN 5 THEN [Biomass System Price]

WHEN 6 THEN [Small PV System Price]

WHEN 7 THEN [Offshore Wind System Price]

END 


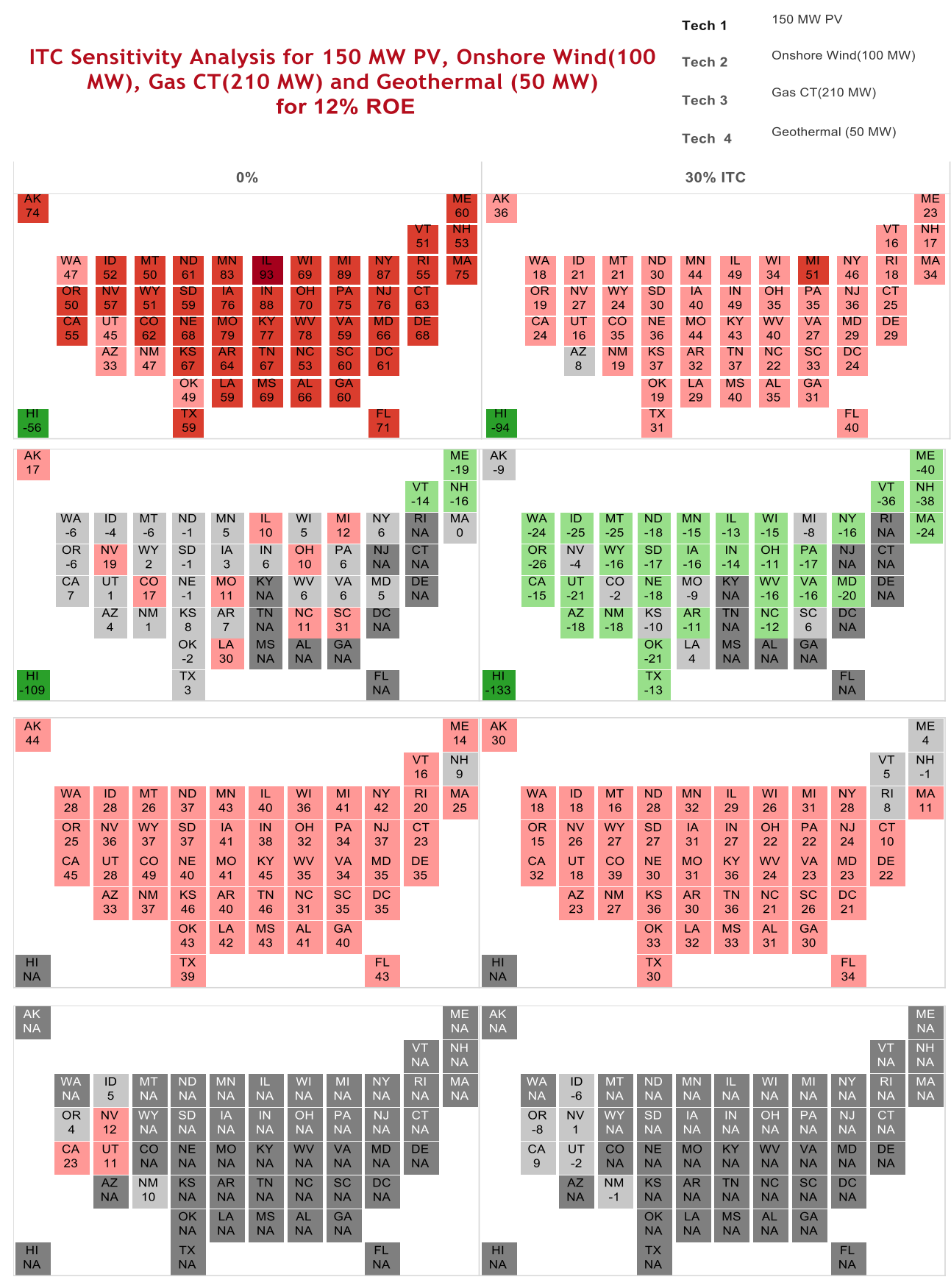

Figure 18. Tiled maps of LEP-System prices for LargePV,Onshore Wind,Gas CC and Geothermal Technology for 2 different ITC Values $(0$ and $30 \%)$.

\subsubsection{PTC Sensitivity Analysis}

Four Tableau worksheets (PTCMap1, PTCMap2, PTCMap3, PTCMap4) were created to map the LEP-System prices on two United States tiled maps for two different PTC values ( 0 and 22 \$/MWh) using an ordinal color scale. The PTC worksheet of the SensitivityAnalysis_Dashboard.xlsx acts as the data source for this worksheet. The D7-PTCMaps dashboard combines all the four worksheets to allow 
comparison of the LEP-System Prices across four technologies (Figure 19). Each worksheet allows selection of one of the eight technologies that are currently being modelled. Therefore, the D6-ITCMaps Dashboard allows selection of four different technologies using TechInput 1, TechInput 2, TechInput 3 and TechInput 4 dropdown menus. Details of some of the Tableau variables are given below:

\section{LEP_System}

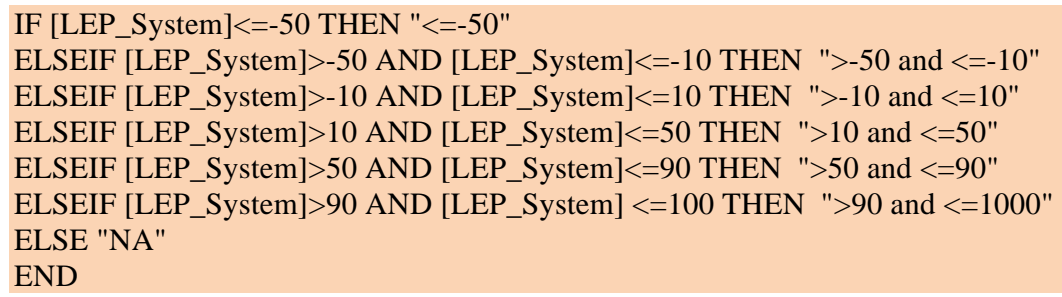

NOTE: Row and space are the attributes used to create the tiled map view with "square" option chosen in the Mark view of the Tableau frontend.

\subsubsection{Accelerated Depreciation Sensitivity Analysis}

Four tableau worksheets (TaxDepLife-Map1, TaxDepLife-Map2, TaxDepLife-Map3, TaxDepLife-Map4) were created to map the LEP-System prices on two United States tiled maps for two different TaxDepLife values (5 and 30 years) using an ordinal color scale. The TaxDepLife worksheet of SensitivityAnalysis_Dashboard.xlsx acts as the data source for this worksheet. The D8-TaxDepLifeMap dashboard combines all four worksheets to allow comparison of the LEP-System Prices across four technologies simultaneously (Figure 20). Each worksheet allows selection of one of the eight technologies that are currently being modelled. Therefore, the D6-ITCMaps Dashboard allows selection of four different technologies using Technology Selection 1/2/3/4 dropdown menus. Details of some of the Tableau variables are given below:

\section{LEP_System}

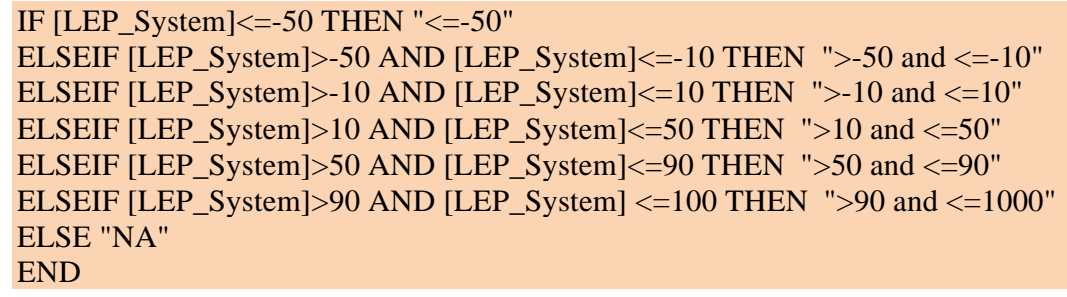

NOTE: Row and space are the attributes used to create the tiled map view with "square" option chosen in the Mark view of Tableau frontend. 
PTC Sensitivity Analysis for 150 MW PV, Small PV (7 MW), Gas CT(210 MW) and Geothermal (50 MW)

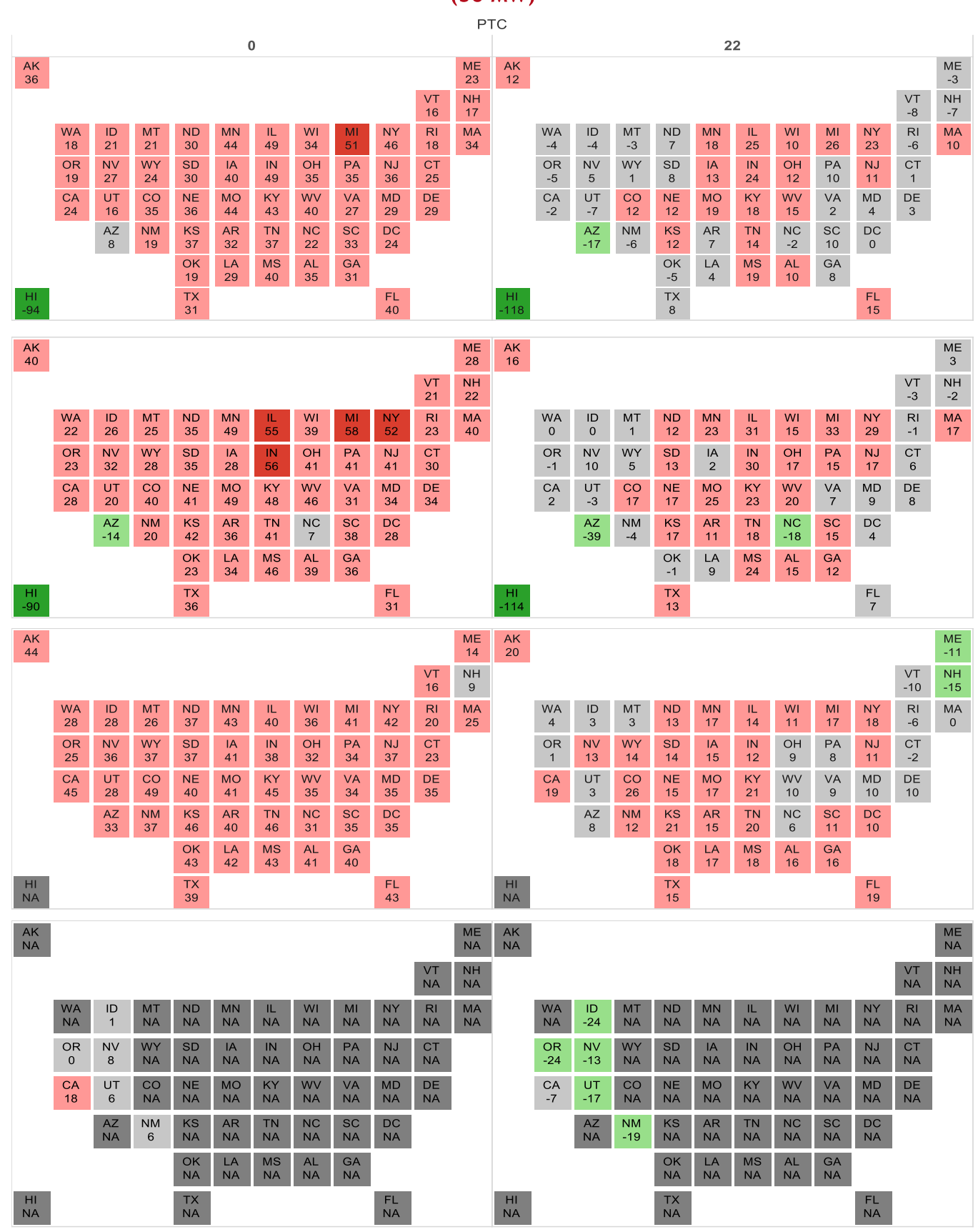

Color Legend

$<=-50$

$>-50$ and $<=-10$

$>-10$ and $<=10$

$>10$ and $<=50$

$\square>50$ and $<=90$

- $>90$ and $<=1000$

NA

Technology Selection 1 $150 \mathrm{MW}$ PV
Technology Selection 2 Small PV (7 MW)
Technology Selection 3 Gas CT(210 MW) Geothermal (50 MW)

Figure 19. Tiled maps of LEP-System prices for Large PV, Onshore Wind, Gas CC, and Geothermal Technology for two different ITC Values $(0$ and $30 \%)$. 
Accelerated Depreciation Sensitivity Analysis for 150 MW PV, Onshore Wind(100 MW), Gas CT(210 MW) and Geothermal (50 MW)

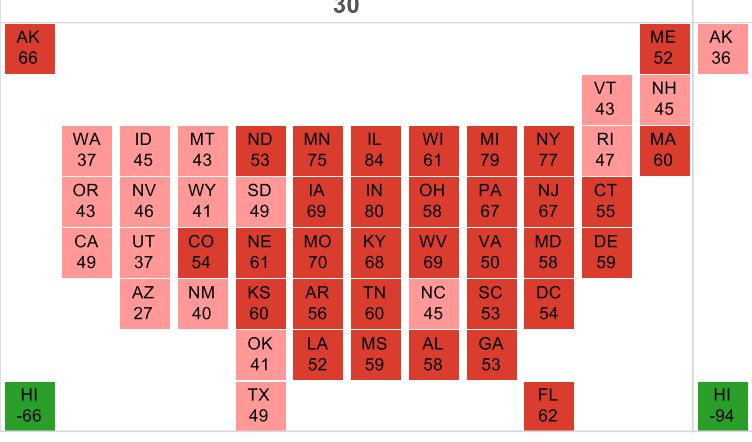

Color Legend

$\square<=-50$

$>-50$ and $<=-10$

$>-10$ and $<=10$

W $>10$ and $<=50$

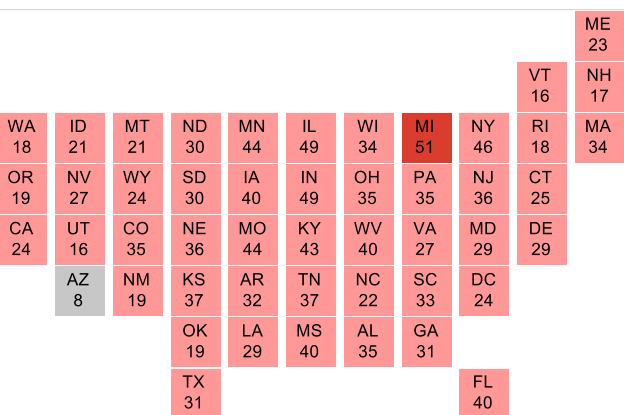

- $>50$ and $<=90$

$\square>90$ and $<=1000$

NA $150 \mathrm{MW}$ PV

Technology Selection 1

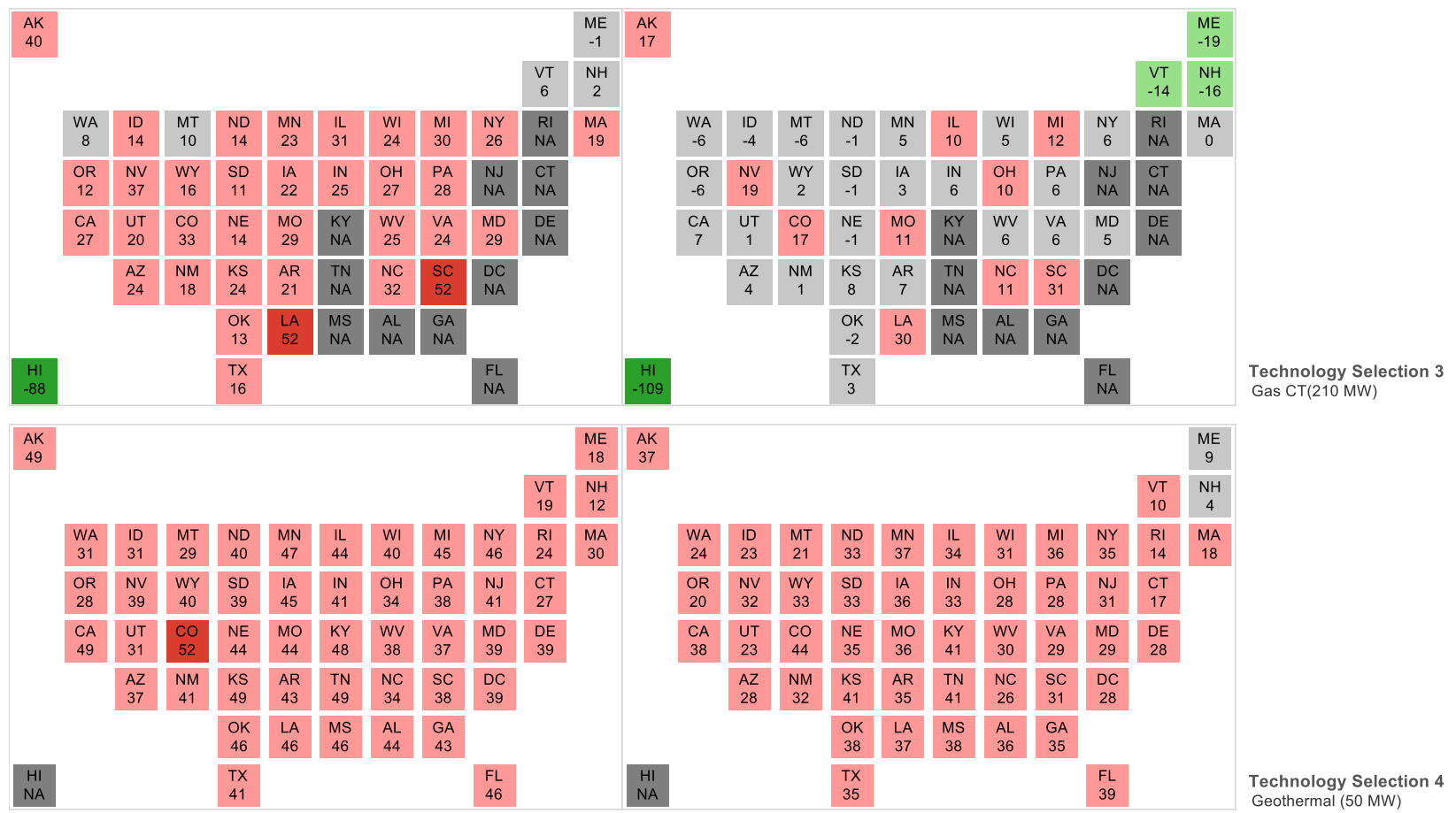

AK
NA

\section{\begin{tabular}{|l|l|l|}
\hline ME & AK \\
NA & NA \\
\hline
\end{tabular}}

\begin{tabular}{l|l|} 
VT & NH \\
NA & NA \\
\hline
\end{tabular}

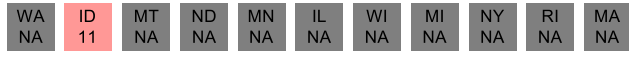

\begin{tabular}{|l|l|l|l|l|l|l|l|l|l|}
\hline OR & NV & WY & SD & IA & IN & OH & PA & NJ & CT \\
10 & 16 & NA & NA & NA & NA & NA & NA & NA & NA \\
\hline
\end{tabular}

\begin{tabular}{llllll|l|l|l|l|l}
$C A$ & UT & CO & NE & MO & KY & WV & VA & MD & DE \\
\hline 31 & 17 & $N A$ & NA & NA & NA & NA & NA & NA & NA
\end{tabular}

$31 \quad 17 \quad$ NA $N A$ NA

\begin{tabular}{|l|l|l|l|l|l|l|l|}
\hline AZ & NM & KS & AR & TN & NC & SC & DC \\
NA & 15 & NA & NA & NA & NA & NA & NA \\
\hline
\end{tabular}

\begin{tabular}{l|l|l|l|l|}
\hline OK & LA & MS & AL & GA \\
NA & NA & NA & NA & NA \\
\hline
\end{tabular}

\begin{tabular}{l} 
HI \\
NA \\
\hline
\end{tabular}

TX
NA

FL

HI
NA

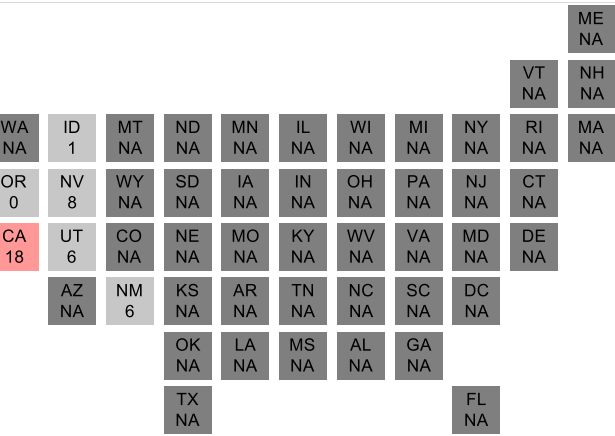

Figure 20. Figure shows eight tiled maps of LEP-System prices for Large PV, Onshore Wind, Gas CT, and Geothermal Technology for two different TaxDepLife Values (5 and 30 years). 


\subsubsection{Current Incentives Map}

To be able to understand the impact of various tax policies and incentives on the economic viability of a new energy project, we first need a reference map to compare against. Using the Reference Cases worksheet of the SensitivityAnalysis_Dashboard.xlsx file, we created a Current Incentives map dashboard by generating eight images using the worksheet and combining them in the "CurrentIncentives-D9" dashboard sheet of the Tableau workbook (Figure 21).

Current Incentives Map
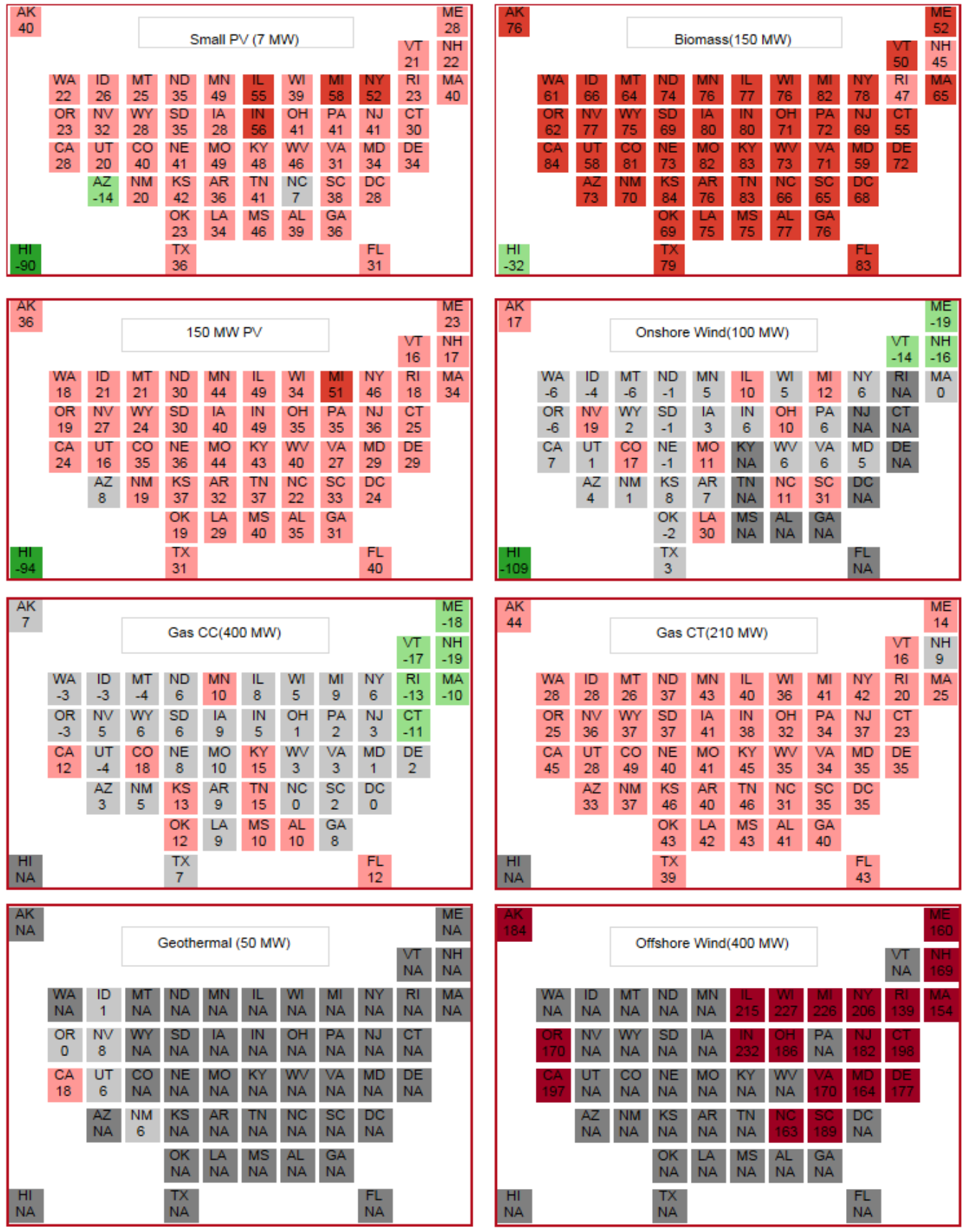

Figure 21. Eight tiled maps of LEP-System prices for Large PV, Onshore Wind, Gas CT, and Geothermal Technology with current valid incentives for ITC and PTC. 


\subsubsection{NoIncentives Map}

To be able to understand the impact of current various tax policies and incentives on the economic viability of a new energy project, we also need a reference map with no incentives. Using the Refcases_Noincentives worksheet of the SensitivityAnalysis_Dashboard.xlsx file, we created a Noincentives map dashboard by generating eight images using the worksheet and combining them in the "NoIncentives-D9" dashboard sheet of the Tableau workbook (Figure 22).
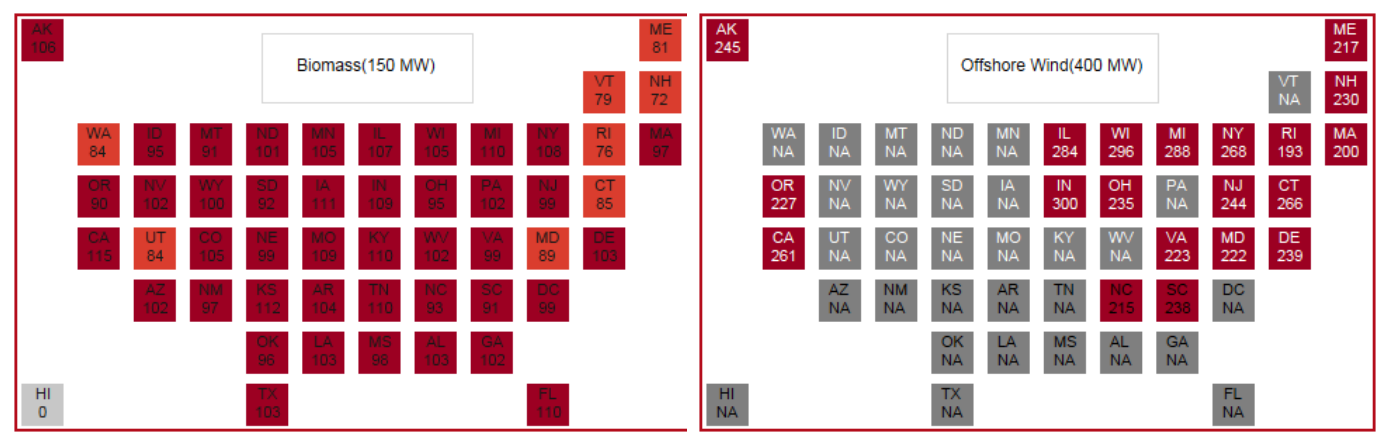

Color Legend Color Lege $>-50$ and $<=-10$ $>-10$ and $<=10$ $>10$ and $<=50$ - $>50$ and $<=90$ $>90$ and $<=1000$ NA
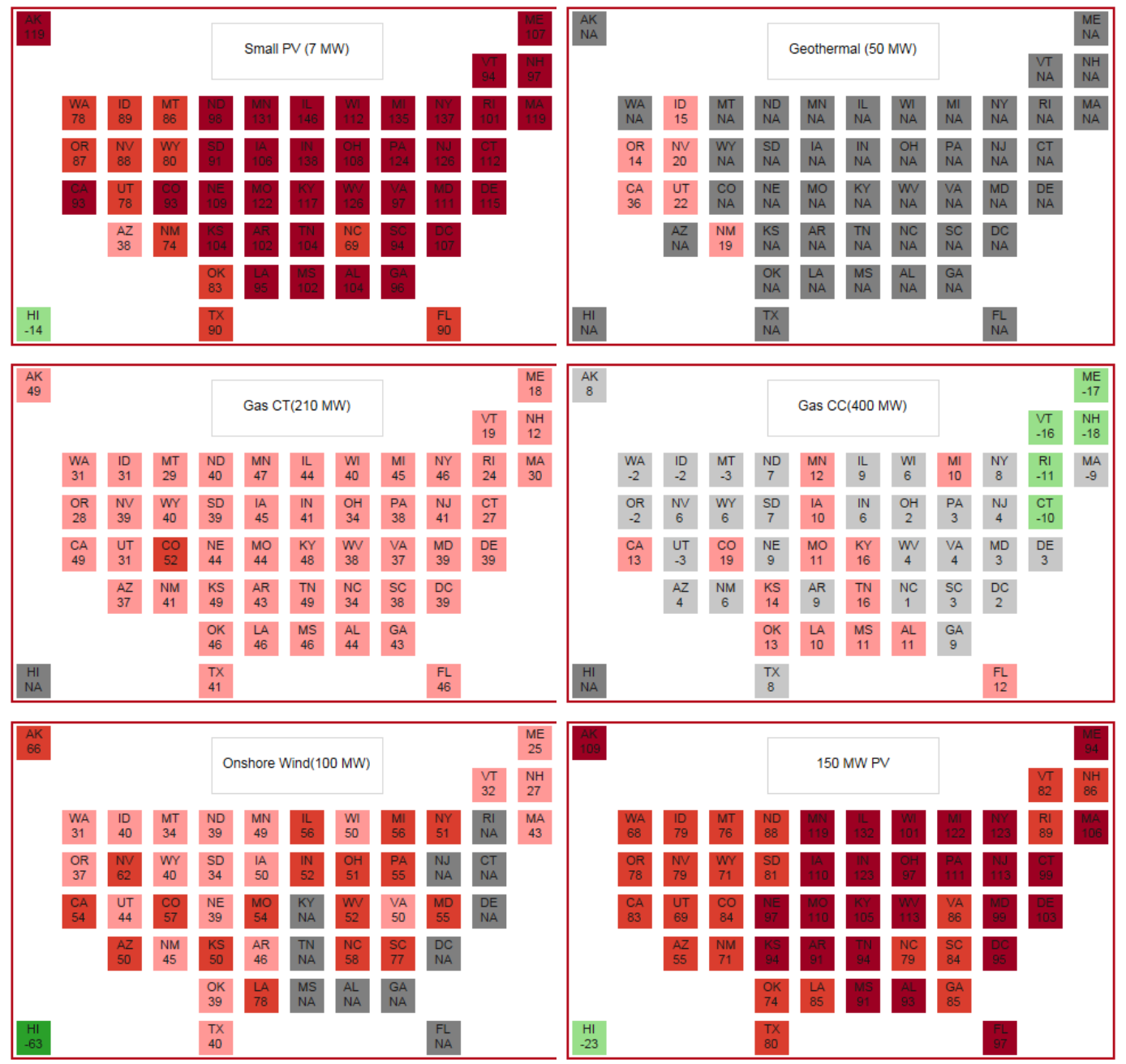

Figure 22. Eight tiled maps of LEP-System prices for Large PV, Onshore Wind, Gas CT, and Geothermal Technology with no incentives for ITC and PTC. 


\subsubsection{Box Plots for ITC Sensitivity Analysis}

Two tableau worksheets named Box Plots-ITC SA and Box Plots-ITC SA2 were created to plot the LEP prices for all the states for four different ITC values as box plots. The ITC-SA-D5 Dashboard combines the two worksheets to allow comparison of the LEP prices between two technologies. Each worksheet allows selection of one of the eight technologies that are currently being modelled. Therefore, the ITC-SA-D5 Dashboard allows selection of two different technologies using Technology Selection 1 and 2 drop down menus. These plots (Figure 23) mainly help to identify outliers by displaying the upper and lower whiskers, quartiles, median values, etc. and the relationship between the ITC and LEP prices.

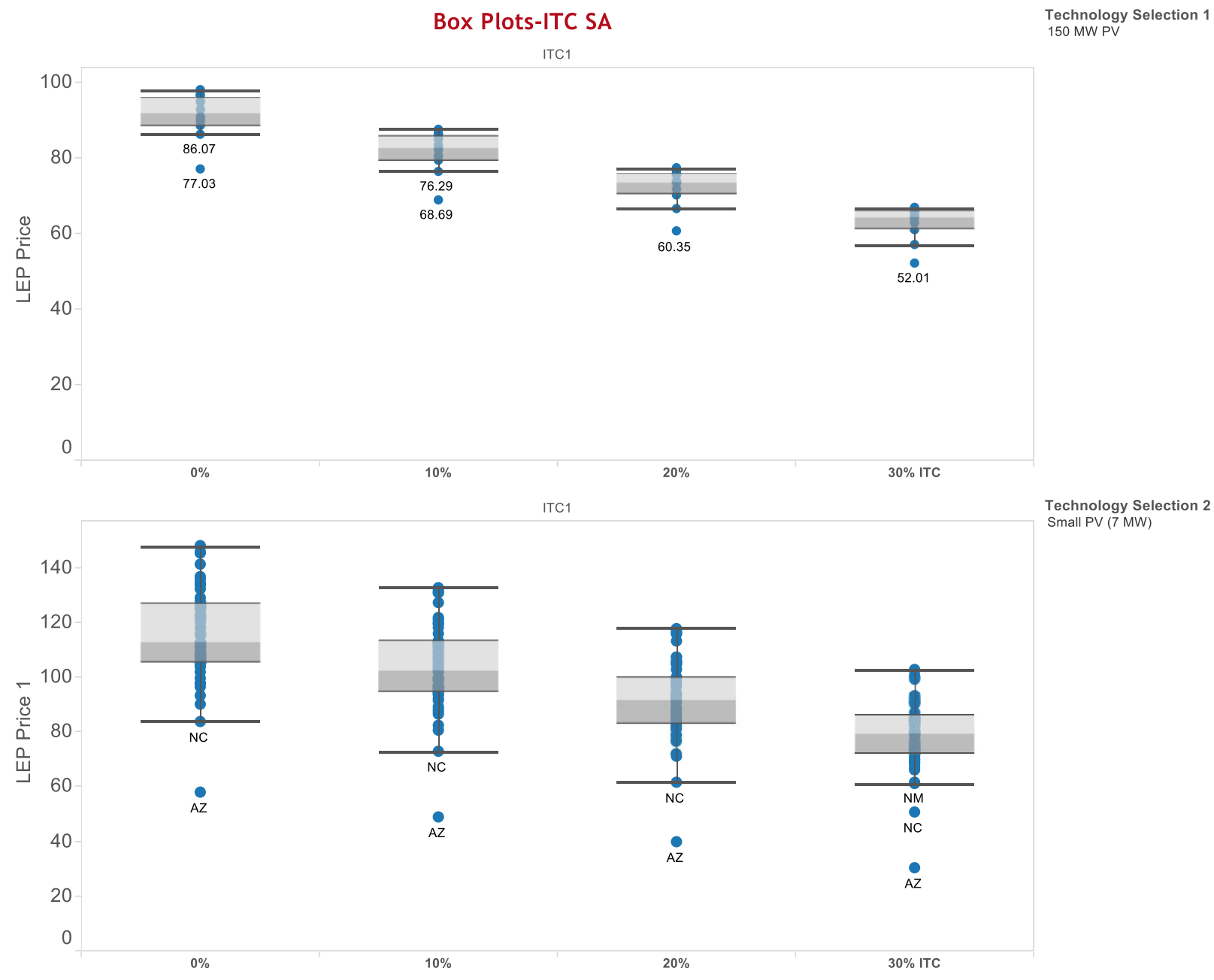

Figure 23. Box plots of LEP prices for Large PV and Small PV Technology for various values of ITC.

\subsubsection{Line Charts for ITC Sensitivity Analysis}

Two tableau worksheets (ITC-SA-LineCharts and ITC-SA-LineCharts1) were created to plot the LEP prices and System prices for all the states for four different ITC values as line charts. The ITC-SA-D1 Dashboard combines the two worksheets to allow comparison of the LEP prices between two technologies. Each worksheet allows selection of one of the eight technologies that are currently being modelled. Therefore, the ITC-SA-D5 Dashboard allows selection of two different technologies using 
Technology Selection 1 and 2 drop down menus. These plots (Figure 24) mainly help to identify the relationship between the ITC and LEP prices. A new parameter (BottomN) has been defined that allows filtering only the top $\mathrm{N}$ states with the least LEP prices.

Technology Selection 1

$150 \mathrm{MW}$ PV

State1

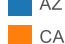

ITC Sensitivity Analysis for 150 MW PV with $12 \%$ ROE and \$10 REC Price

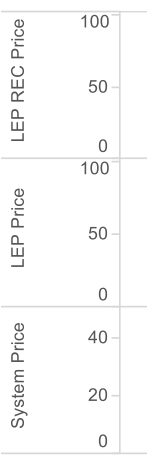

$0 \%$

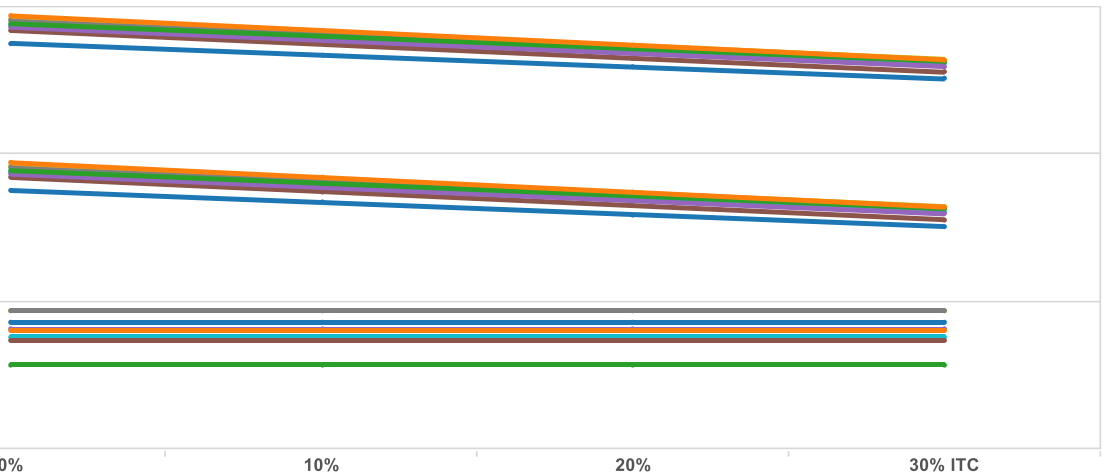

ITC1

Technology Selection 2 Small PV (7 MW)

ITC Sensitivity Analysis for Small PV (7 MW) with $12 \%$ ROE

ITC1

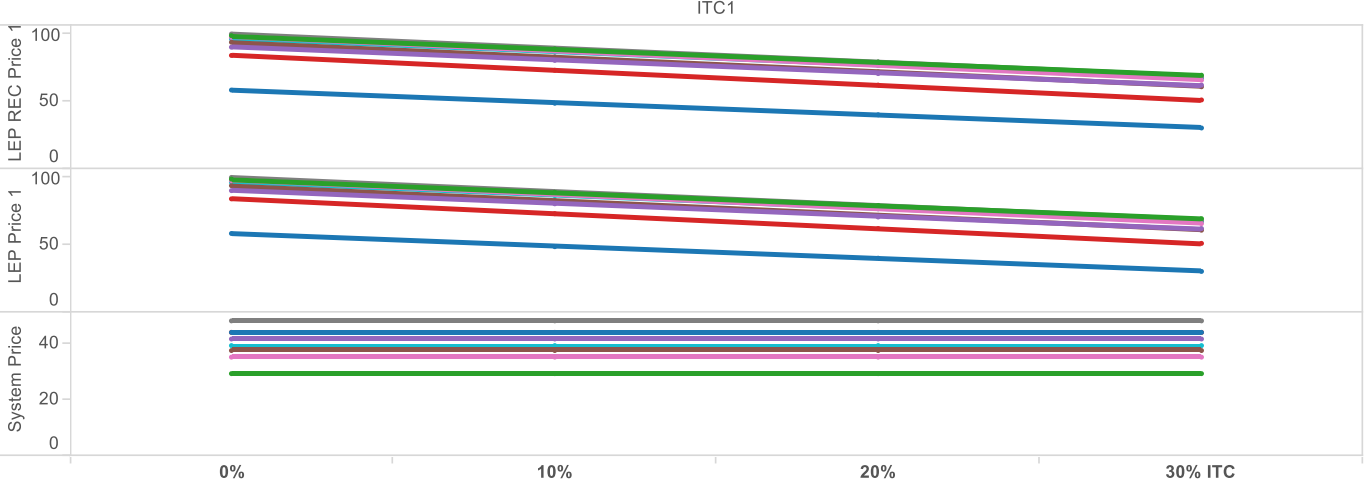

Figure 24. Line of LEP prices and System prices for Large PV and Small PV Technology for various values of ITC.

Similarly, the ITC-SA-D2 Dashboard displays the ROE and ROE D+E values for all states. Therefore, the ITC-SA-D2 Dashboard allows selection of one of different technologies using Technology Selection 1 drop down menus. These plots (Figure 25) mainly help identify the relationship between the ITC and ROE D+E prices. Color represents different states. 


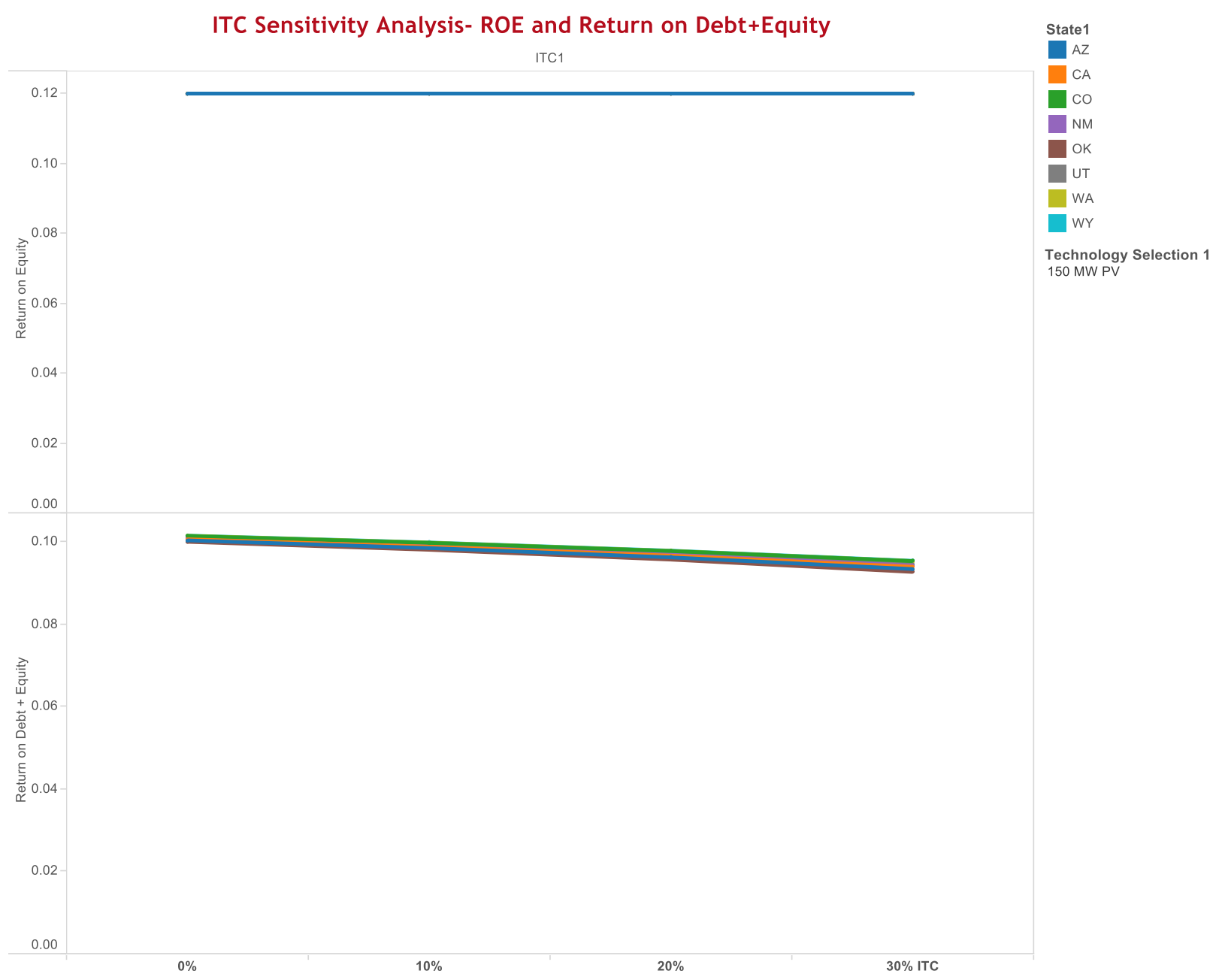

Figure 25. ROE prices and ROE D+E prices for LargePV and Small PV Technology for various values of ITC.

\subsubsection{NPV Charts for ITC Sensitivity Analysis}

The ITC-SA-D4 Dashboard displays REC Revenue, Energy Revenue, Fed Tax Credits, Debt Issued, Fed Incom $+\mathrm{CO}_{2}$ Taxes, State/Local Net Tax, Fuel+O\&M Cost, Capital Outlays, Int+Debt Repaid and Net Equity values for selected states (Figure 26). The ITC-SA-D2 Dashboard allows selection of one of different technologies using the Technology Selection 1 dropdown menu. Color distinguishes the different attributes displayed as a stacked bar chart. ITC has four values in this dashboard: $0 \%, 10 \%$, $20 \%$, and $30 \%$ ITC. 


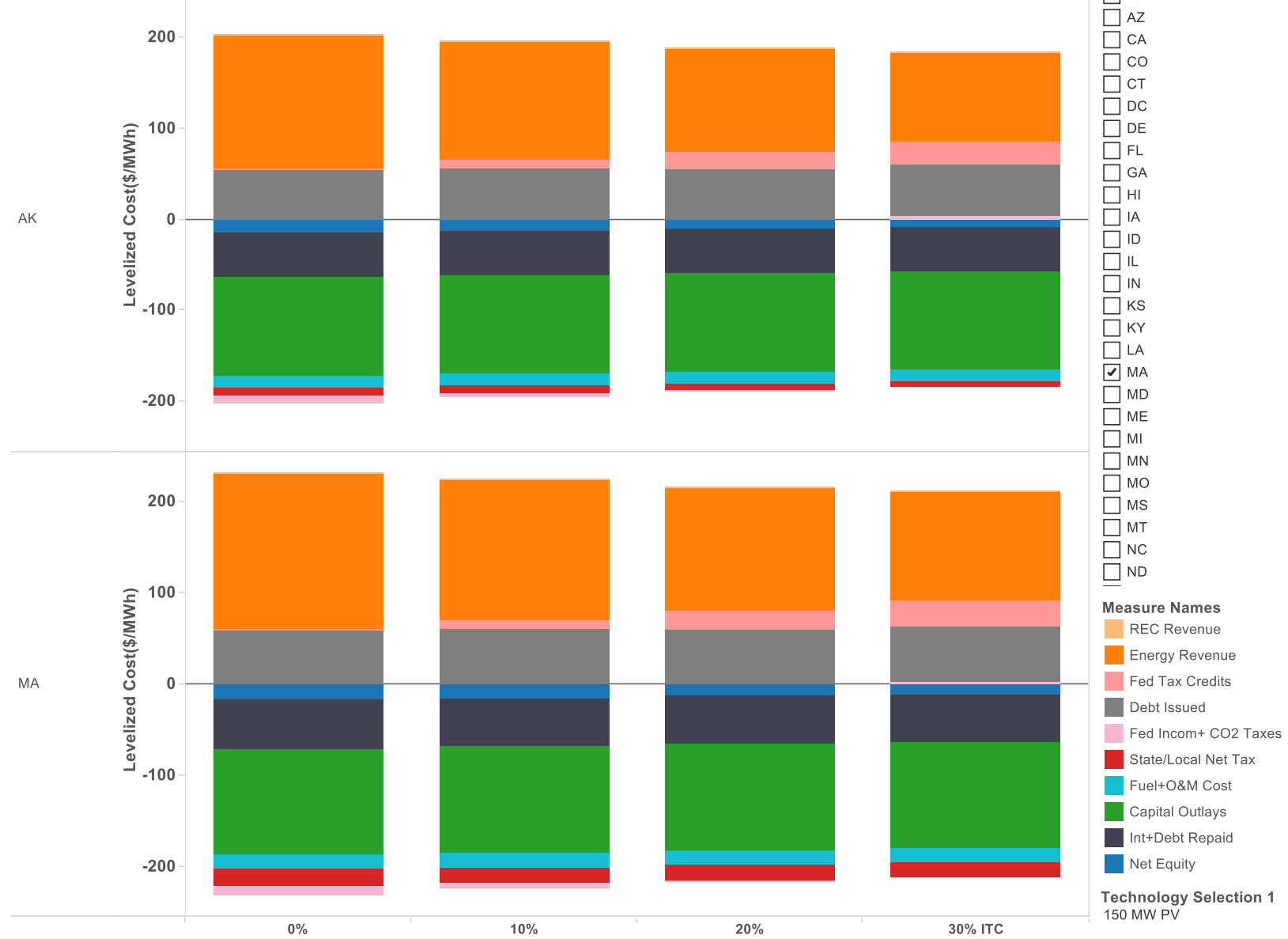

Figure 26. NPV Dashboard for Large PV Technology displaying values for different ITC inputs.

\subsubsection{Net Cash Flow Charts for ITC Sensitivity Analysis}

The ITC-SA-D3 Dashboard displays Net Taxes, Operating Costs, Revenue, Net Debt, Capital Costs and Net Equity values for selected states (Figure 27). The ITC-SA-D3 Dashboard allows selection of different technologies using the Technology Selection 1 drop down menu. Color distinguishes the different attributes displayed as a stacked bar chart. ITC has four values displayed in this dashboard: $0 \%, 10 \%$, $20 \%$, and $30 \%$ ITC. 
Return on Equity @12\% for 150 MW PV

State1 ITC

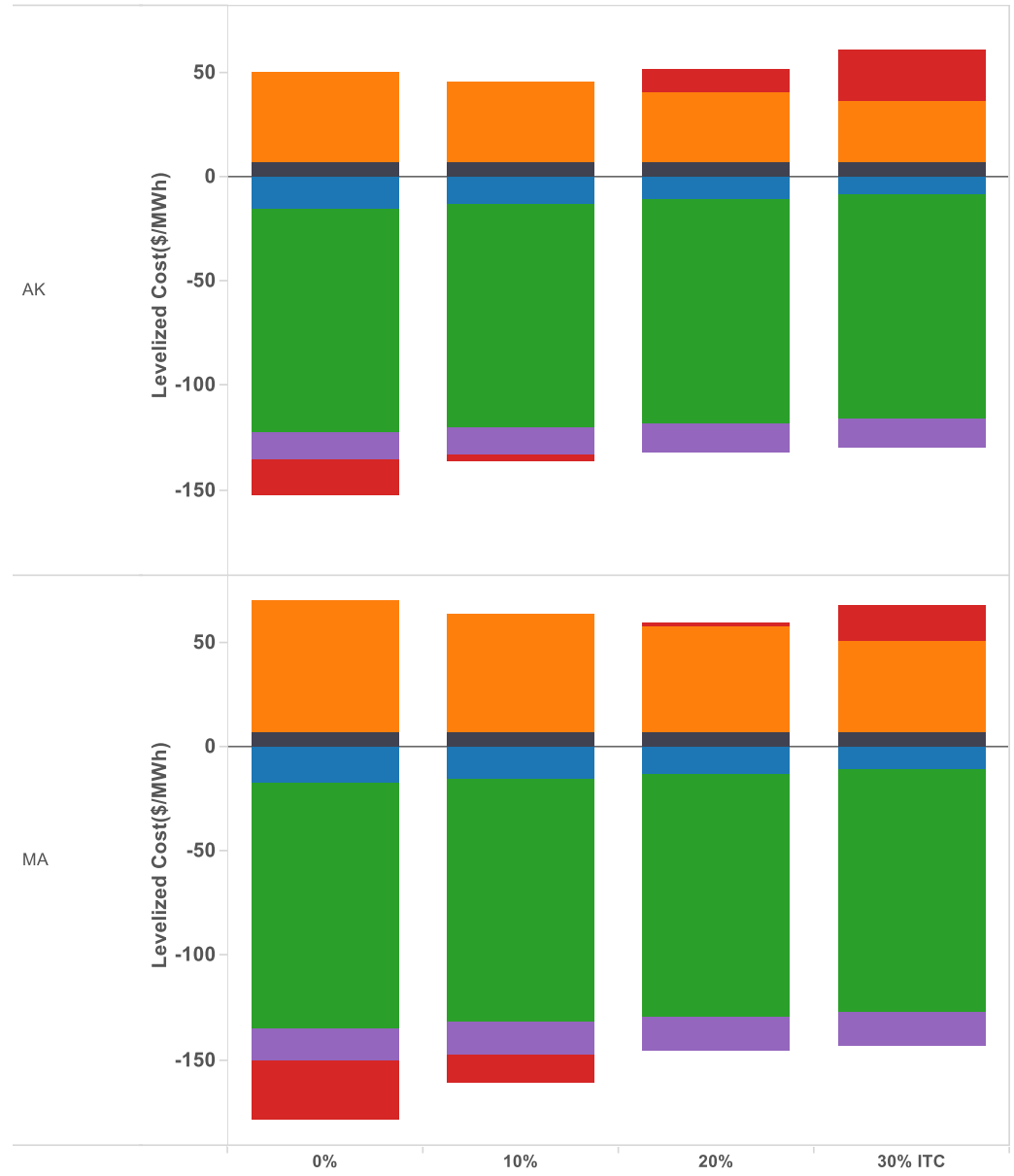

Measure Names

$\square$ Net Taxes

Operating Costs

Revenue

$\square$ Net Debt

Capital Costs

Net Equity

Figure 27. NetCashFlow Dashboard for Large PV Technology displaying values for different ITC inputs. 


\section{PFMT OPERATIONS}

\subsection{EXCEL DASHBOARD}

In the Excel workbook, the first worksheet (Dashboard) provides the location for key inputs to be set (name, description, technology); the solution objective to run (Return on Equity, Return on Debt + Equity, $\mathrm{CO}_{2}$-adjusted System Price, Fixed Price, Stored Case); and key output results. The outputs include a table of the levelized cost of the different cost components. A map shows the state-by-state values for different parameters, and other charts show the cash flow and calculated versus system prices.

\subsubsection{Input settings}

The Case Name can be anything and appears in the title of the map on the page. The Case Description can be longer to reference distinguishing features of this run. The Technology selection is limited to those listed in the TechnologyInputs worksheet, and the State listed is used to identify state showing in the net cash flow chart, as well as within FINModule.

The energy price can be adjusted for each state to meet a variety of objective functions. The inputs to define the objective are listed in Table 15. A desired Return on Equity or Return on Debt + Equity can be entered. The Return on Debt + Equity includes both equity cash flows and debt-related cash flows and can be thought of as the return on capital or pre-tax weighted average cost of capital (WACC).

Alternatively, the prices from one of the cases stored earlier can be applied to understand the impact of changing a policy but leaving the prices unchanged. The third parameter lets the user specify which case to use. Alternatively, the user can specify a single price in the fourth parameter that all states use for their energy price. A user can also specify that the $\mathrm{CO}_{2}$ adjusted System Price be used for all years. The fifth parameter is where the user specifies which of the five objectives should be used in the calculation by use of a drop-down list of choices.

Table 15. Dashboard Objectives Inputs

\begin{tabular}{|r|c|c|}
\hline & Desired & Actual \\
\hline Return on Debt + Equity & $9.00 \%$ & $9.41 \%$ \\
\hline Return on Equity & $12.00 \%$ & $12.00 \%$ \\
\hline Stored Case to Use for Price & 2 & \\
\hline Fixed Price to Use & $\$ 60.00$ & \\
\hline Objective to Solve For & ROE & Return on Equity \\
\hline
\end{tabular}

\subsubsection{Results Table}

Two tables are included that disaggregate the project cash flow stream into the net present value using the desired WACC value showed elsewhere on the sheet. The first table disaggregates on specific categories, and the second table shows the same information arranged by the different groups interacting with the project, similar to what is shown in Figure 1. Examples of the two tables are shown in Table 16 and Table 17. The values are shown both in thousands of $\$$ and in $\$ / M W h$. The latter is found by dividing the NPV of costs by the NPV of the production from the project. 
Table 16. Results using desired return on debt + equity @ 9\% for Large PV in New York

\begin{tabular}{|c|c|c|c|c|c|c|c|c|c|c|c|}
\hline $\begin{array}{c}\text { Energy } \\
\text { Revenue }\end{array}$ & $\begin{array}{c}\text { REC } \\
\text { Revenue }\end{array}$ & $\begin{array}{c}\text { Fuel+ } \\
\text { O\&M } \\
\text { Cost }\end{array}$ & $\begin{array}{l}\text { Capital } \\
\text { Outlays }\end{array}$ & $\begin{array}{l}\text { Reserves } \\
\text { Accounts }\end{array}$ & $\begin{array}{l}\text { Debt } \\
\text { Issued }\end{array}$ & $\begin{array}{l}\text { Interest+ } \\
\text { Debt } \\
\text { Repaid }\end{array}$ & $\begin{array}{c}\text { Fed } \\
\text { ITC+PTC }\end{array}$ & $\begin{array}{l}\text { Fed } \\
\text { Taxes }\end{array}$ & $\begin{array}{c}\text { State/Local } \\
\text { Net Tax }\end{array}$ & $\begin{array}{l}\text { Net to } \\
\text { Equity }\end{array}$ & $\begin{array}{l}\text { Net to } \\
\text { Debt + } \\
\text { Equity }\end{array}$ \\
\hline$\$ 332,739$ & $\$-$ & $\$-43,536$ & $\$-326,332$ & $\$-7,224$ & $\$ 171,785$ & $\$-150,184$ & $\$ 81,635$ & $\$ 8,360$ & $\$-37,546$ & $\$ 29,696$ & $\$ 8,095$ \\
\hline 119.96 & 0.00 & -15.70 & -117.65 & -2.60 & 61.93 & -54.15 & 29.43 & 3.01 & -13.54 & $\$ 10.71$ & $\$ 2.92$ \\
\hline
\end{tabular}

Table 17. Results by group using desired return on debt + equity @ 9\% for Large PV in New York

\begin{tabular}{|c|c|c|c|c|c|}
\hline Ratepayers & $\begin{array}{l}\text { Suppliers \& } \\
\text { Employees }\end{array}$ & Creditors & $\begin{array}{l}\text { Federal } \\
\text { Taxpayers }\end{array}$ & State Taxpayers & Equity Holders \\
\hline$\$ 332,739$ & $\$-369,868$ & $\$ 14,377$ & $\$ 89,995$ & $\$-37,546$ & $\$ 29,696$ \\
\hline 119.96 & -133.35 & 5.18 & 32.45 & -13.54 & 10.71 \\
\hline
\end{tabular}

\subsubsection{Charts}

A map has been developed that gives state-by-state color changes based on the values for that state. A user can select which values to appear in the map by changing the label in the drop-down menu on cell J12: (LEPR, LEP, LEP-System, LEP Diff, ROE). The LEPR option shows the levelized price for energy during the fixed price life plus any REC price, and the LEP plot shows only the calculated energy price. The LEP-System option subtracts the average system price from this energy only price to reflect the competitiveness of the energy cost from the technology. If a project has a significant REC income, then the energy price will be lower to receive the desired ROE. The LEP Diff option shows the LEP minus the price from a stored case, which is identified in cell $\mathrm{K}$ through 12. Lastly, ROE displays the actual return on equity for each state.

An example map is shown in Figure 28. The map displays a color-coded state map with a legend showing the values for major colors in the map. High values at or above the top value in the legend are all given the dark red color. This color then fades to almost white as it approaches the bottom of the second range in the legend. The white range is for a narrow span of colors such as those near the marginal cost for the state. Colors below that range start at very light blue, becoming darker as they approach the value in the last block of the legend. States with very high values (i.e., not widely available in those states), have a grey color. The actual mapped values for each state are listed to the right of the map on the worksheet. If the user desires to change the ranges displayed, he/she can do so in the brown cells in Q70:T94.

Two other charts are also found on the Dashboard. The Project Cash Flow chart is a stacked column graph showing the components of project's cash flow. In every year, cash flow must balance, so the graph will be symmetrical around the x-axis. During construction, funds are received from debt and equity holders (positive) and spent on construction-related activities or in the buildup of reserve accounts related to debt and upcoming operating costs. (Construction costs dominate in the example.) The LEP versus system price is an $x-y$ plot of the project LEP and the system price. Those states with LEPs above system price would be above the black diagonal line, and those below the line have lower prices. 


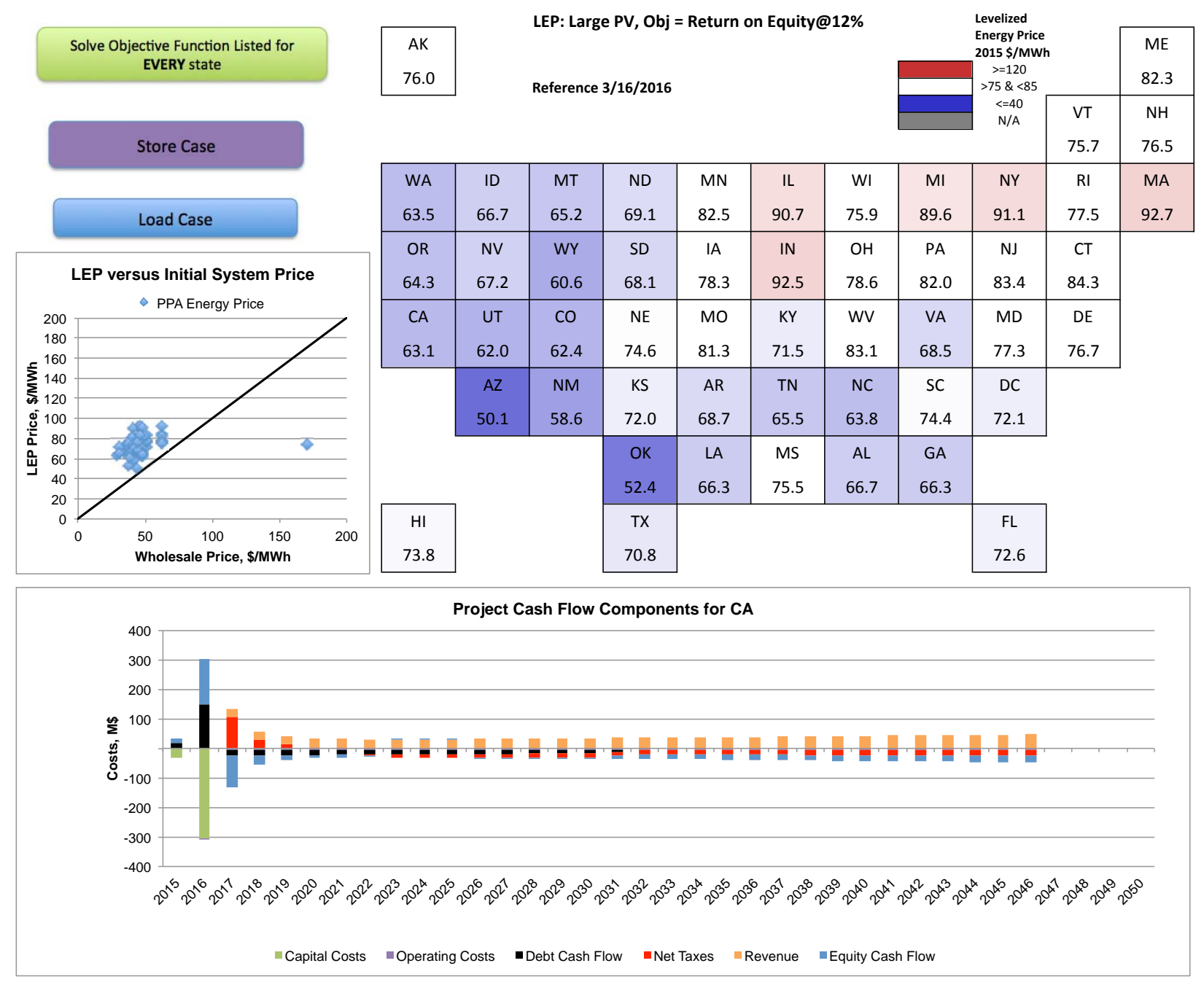

Figure 28. Example map and other charts from Dashboard for Large PV.

\subsubsection{Dashboard Operations}

There are three macro buttons underneath the objectives inputs table. The largest, green button will calculate the price for every state based on the objective selected, storing the results at the bottom of FINModule. The other two macros allow the user to store the input and key outputs of up to 20 different case runs, and the third button will load a specified case back into the worksheets. The case name and description of each of the 20 cases can be found listed below the charts and buttons. Each technology is stored in a separate column on StoredOutputs, so there can be up to 20 cases for each technology stored. Cases 1 through 10 are used in the MultiCase analysis described in Section 5.2. Case 11 currently stores the Reference cases to allow a user to quickly reload default results back into the model

The user can make any changes to inputs on any sheet and then select the green button to calculate the impact on all of the states. He/she can then examine the values for any state by entering a state code into the input block on the Dashboard. This should update the charts, tables, and FINModule calculations to match the parameters for that state. However, if the user then changes any other inputs, then he or she should press the green button after making the changes because the Dashboard charts only select data from the stored results at the bottom of FINModule, rather than selecting the live data in FINModule (which will not reflect changes otherwise). 
As an example, suppose a user wants to change the federal income tax rate and run the cases. To do this, the user would:

1. Go to the FINModule worksheet.

2. Change the Fed. Income Tax Rate in cell G3 from $35 \%$ to whatever value is desired.

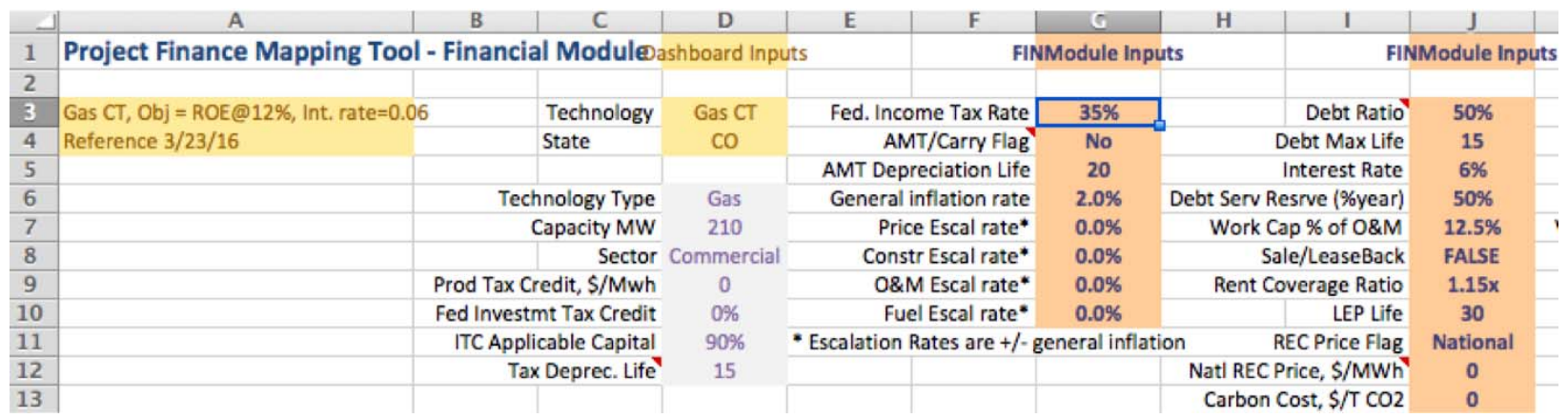

Figure 29. FINModule worksheet input section.

3. Go to the Dashboard worksheet.

4. Make a change to the Case Name (B2) and/or Description (B3) to identify the new case. (Note: In the Case Name, there may be an equation to generate it based on other parameters. The user can use it as-is, modify the equation, or type his or her own case name.)

\begin{tabular}{|c|c|c|c|c|c|}
\hline- & A & B & C & D & $\mathbf{E}$ \\
\hline 1 & & & & & EPSA PRC \\
\hline 2 & Case Name & \multicolumn{3}{|c|}{ Gas CT, Obj= RQ $@ 12 \%$, Int. rate=0.06 } & \\
\hline 3 & Case Descrip & \multicolumn{2}{|c|}{ Reference $3 / 23 / 16$} & & \\
\hline 4 & Technology & Gas CT & & $\begin{array}{c}\text { Energy } \\
\text { Revenue }\end{array}$ & $\begin{array}{c}\text { REC } \\
\text { Revenue }\end{array}$ \\
\hline 5 & State (for CF graph & $\mathrm{CO}$ & & 494,396 & 0 \\
\hline 6 & \multicolumn{2}{|c|}{ Levelized Energy Price, \$/MWh } & 76.09 & 95.05 & 0 \\
\hline 7 & \multicolumn{2}{|c|}{ Energy+REC Price, $\$ / M W h$} & 76.09 & & \\
\hline 8 & & & Desired & Actual & \\
\hline 9 & \multicolumn{2}{|c|}{ Return on Debt + Equity (WACC) } & $9.00 \%$ & $10.40 \%$ & \\
\hline 10 & \multicolumn{2}{|c|}{ Return on Equity } & $12.00 \%$ & $12.00 \%$ & \\
\hline 11 & \multicolumn{2}{|c|}{ Stored Case to Use for Price } & 12 & & \\
\hline 12 & \multicolumn{2}{|c|}{ Fixed Energy Price to Use } & $\$ 90.00$ & & LEPR, \\
\hline 13 & \multicolumn{2}{|c|}{ Objective to Solve For } & ROE & ROE@12\% & \\
\hline
\end{tabular}

Figure 30. Dashboard worksheet input section.

5. Select the Technology to be studied in B4.

6. Ensure that other inputs, such as the desired objective in C13, are selected.

7. Press the green button to re-solve the model for all 50 states (plus the District of Columbia).

\section{Solve Objective Function Listed for EVERY state}

8. Examine the new map values and colors, LEP versus system prices, and/or cash flow as desired. 
9. Change the state in cell Dashboard!B5 to select a state in the cash flow graph and FINModule data.

10. Examine any other data of interest in FINModule.

If the user wishes to change one of the technology-specific variables (as shown in Table 10) then he/she would select the TechnologyInputs sheet instead of FINModule sheet for steps 1 and 2. If the user wished to change a state-specific value, he/she would select either the StateIncent sheet or StateInputs sheet to make the change.

\subsection{MULTI-CASE ANALYSIS}

Analysts may wish to evaluate the impact of changing various key inputs over a range of values on one or more technologies. This is done on the MultiCase worksheet.

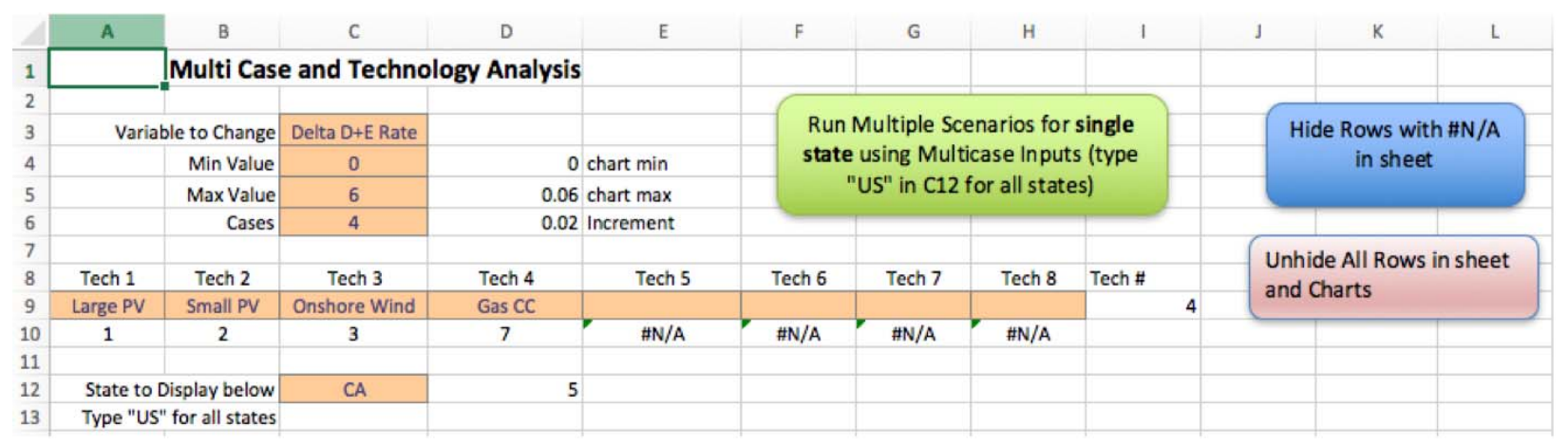

Figure 31. MultiCase worksheet input section.

On the MultiCase sheet, the user can specify in cell C3 which variable he/she wants to vary. The current list includes:

- Investment Tax Credit

- Production Tax Credit

- Income Tax Rate

- Tax Depreciation Life

- $\mathrm{CO}_{2}$ Cost

- Return on Equity

- Interest Rate

- Return on Equity and Interest Rate

- National REC Price

The user then picks minimum and maximum values and the number of cases to be run (up to 10 per technology) in cells C4:C6. The variable is set at the minimum in the first case. If the numbers of cases (C6) is set at 1 , then only the minimum value is run in the analysis. An increment to be added to the variable in each case is calculated in cell D6:

$$
\text { Increment }=\frac{\text { Max Value }- \text { Min Value }}{(\text { Cases }-1)}
$$

The user can select any combination of the eight technology options to be analyzed. The user lists which options in cells A9:H9. If fewer technologies than eight are to be compared, then the remaining cells 
should be left blank. If the user wants to fill in the Tableau export files, he or she should have all eight technologies listed in A9:H9 (in any order) and select two cases to be run, one at the minimum and one at the maximum. Furthermore, the user should set the state to be "US" in cell C12. This causes the model to calculate and store the values for all of the states rather than just the one listed.

Three macro buttons are included on the worksheet. The green button, "Run Multiple Scenarios for single state using Multicase inputs (type 'US' in C12 for all states)" will run the model for up to 72 cases, once for each case for each technology selected. If 'US' is selected, it will run $72 \times 51$ or 3,672 times). The results for each are stored in the worksheet StoredOutputs in eight major columnar sections (of 234 columns each), one section for each of the technology options and a block of 80 rows for each of the cases, 1 through 10.

Due to the way Excel plots columns charts, the best way to avoid plotting all eight cases per technology (even when fewer were run) is to hide the rows with no data. This is done with the "Hide Rows with \#N/A in sheet" macro. If the cases are rerun with more cases per technology, the user should use the last button "Unhide all rows" and then rehide the empty rows to show the new complete set.

A variety of graphs have been set up that show some of the key summary data from the cases. Currently, four graphs display results from up to all eight technology options. The LEP and ROE are shown as lines for each technology. The levelized costs are shown in two different stacked-bar charts. One consolidates all of the cash flow into six categories (Figure 32), and the second chart gives more detail by plotting ten categories by splitting the revenue, taxes, and debt into multiple categories (Figure 33).

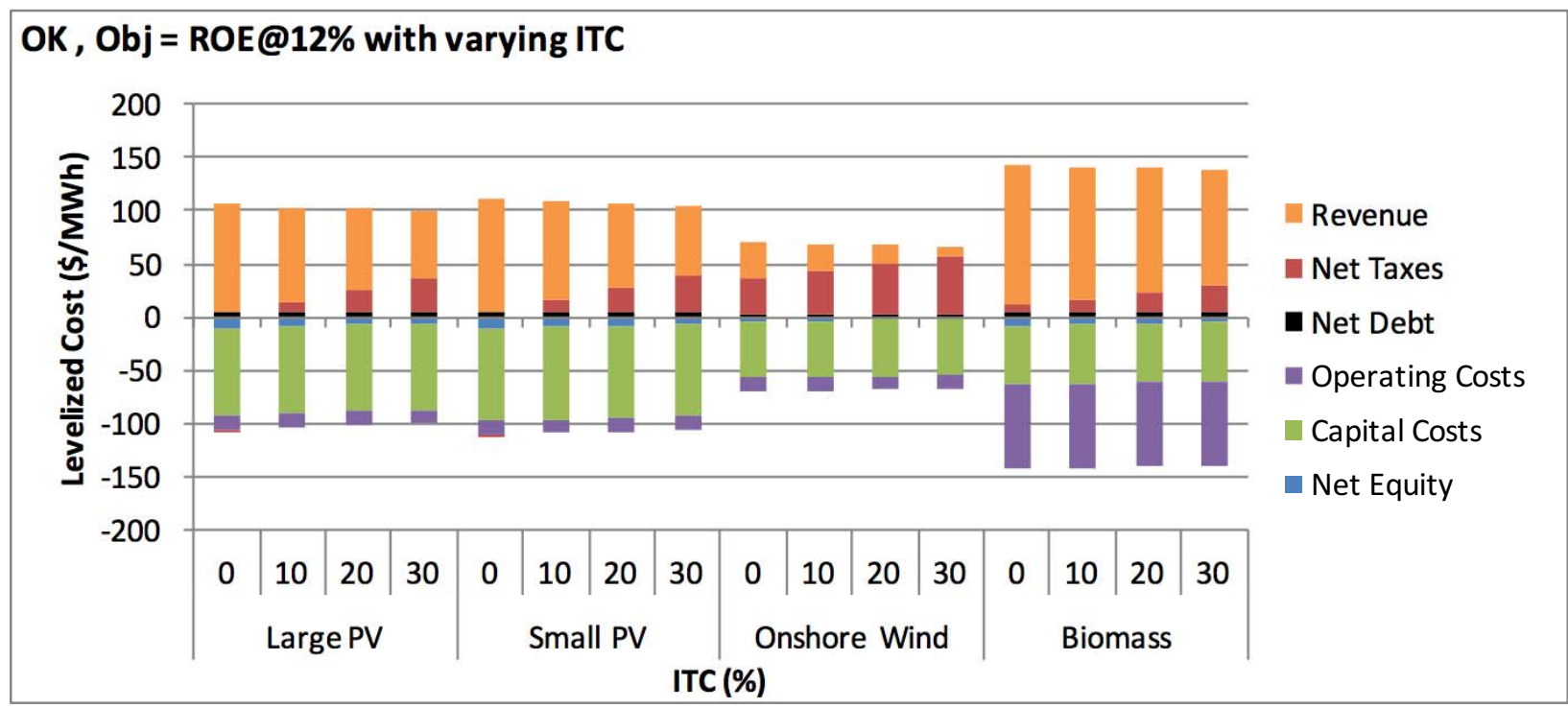

Figure 32. Comparison of ITC effects on levelized costs for four technologies in Oklahoma. 


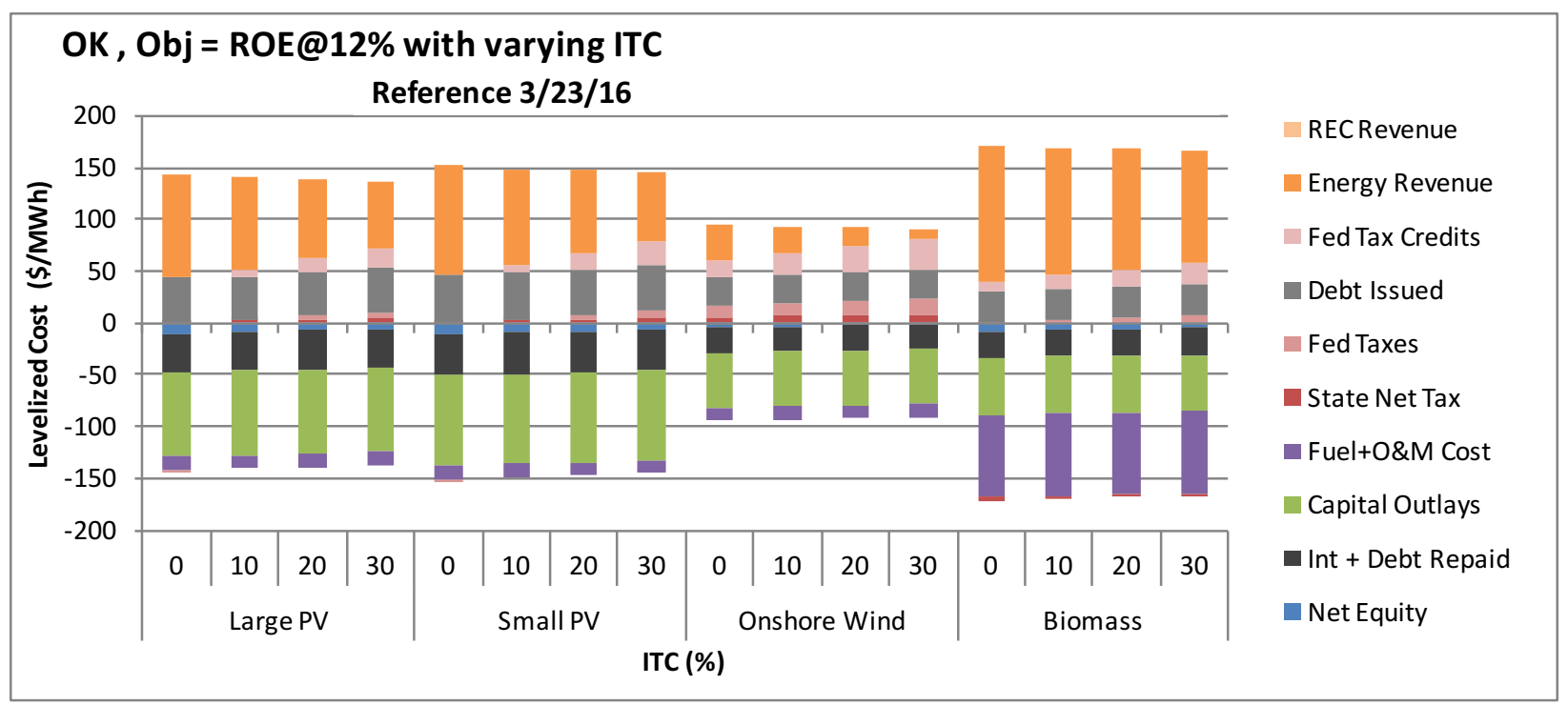

Figure 33. Comparison of ITC effects on levelized costs for four technologies in Oklahoma.

As an example, suppose a user wishes to view the impact of different values for a PTC, such as 0,11 , and 22 \$/MWh. He/she would:

1. Select PTC from the drop-down list of Variable to Change (C3). See Figure 31 for a picture of the Multicase input area.

2. Put 0 in cell $\mathrm{C} 4$ for the Min Value.

3. Put 22 in cell C5 for the Max Value.

4. Put 3 in cell $\mathrm{C} 6$ for the Cases number.

5. Select the name from the drop-down list on cells A9:H9 (or leave blank) for each of the technologies to be analyzed.

6. Check that other variables for the case on Dashboard, FinModule, TechnologyInputs, and/or StateInputs (e.g., description, objective to solve, other financial or technology parameters) are set correctly.

7. On the MultiCase sheet, click on the green macro button. The model will proceed to run the model for each case and technology.

8. To ensure all cases are being graphed, click on the "Unhide All Rows in sheet" and the "Hide Rows with \#N/A in sheet" buttons.

9. Select which state to be shown on the graphs in cell C12.

If a user wants to create variations of the graphs that can be modeled by the steady increment of values from minimum to maximum, then the cases can be run one at a time through the single case method on the Dashboard, storing the case in the desired row. (The program automatically stores the technology in its corresponding column.) 
As an example, under MACRS, depreciable property has a tax depreciation life over which its cost is recovered over $3,5,7,10,15,20,27.5$, or 31.5 years, depending on the type of property, and through use of statutory recovery methods. Meanwhile, the plants are generally modelled to have a 30-year book depreciation schedule. The MACRS method uses a double-declining balance (or 1.5 declining balance depending on the life), and book depreciation is modelled with a straight-line depreciation. An approximation is to use 30 years for the tax life, but to truly model the value of MACRS, one would need to calculate the cost profile if taxes were based on book depreciation. This eliminates all deferred tax calculations. To do this, the user can put the word "Book" as the tax depreciation life. This will set the tax depreciation to the book value for each year within FINModule.

Rather than having to increment to each technology and store the results, a macro has been set up on the Dashboard that runs the model for each of the technologies using all of the input settings in place. It will also ask which case row to store the runs in.

To model this, the user should put the word "Book" in the TechnologyInputs worksheet's cells B10:I10. The user then selects each technology in turn on the Dashboard, clicks the button to calculate all states, and stores the results in a specific case row, such as row 5. Potentially, the user could:

1. In MultiCase set the min, max, and cases set at 5, 20, and 4, respectively, to run the set of cases with tax life at 5, 10, 15, and 20 years.

2. Set the tax life in TechnologyInputs!B10:I10 to Book.

3. Click the Orange button to the top right in Dashboard (cells R2:T4).

\section{Run All Techs and States$$
\text { and store in any case (1-20) }
$$

4. It will ask which case row to store the results in. Type 5 .

5. Lastly, the user should change the number of cases in MultiCase!c6 to 5 and run the Unhide and Hide macros.

The graphs will show the levelized price calculated and cost components for any state chosen. The software then plots the Book values at 30 years based on the actual book value. 


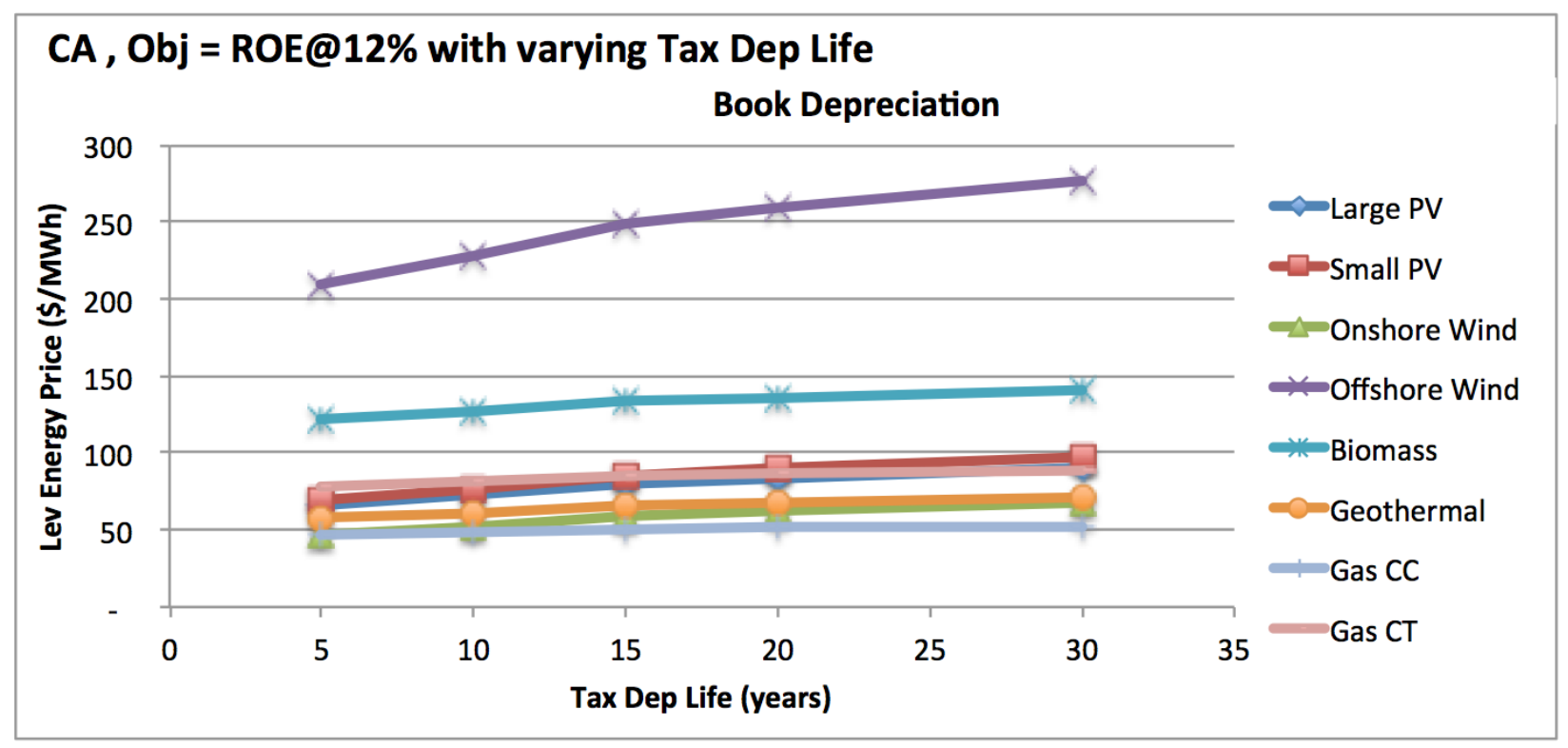

Figure 34. Tax depreciation effects on levelized prices for eight technologies in California.

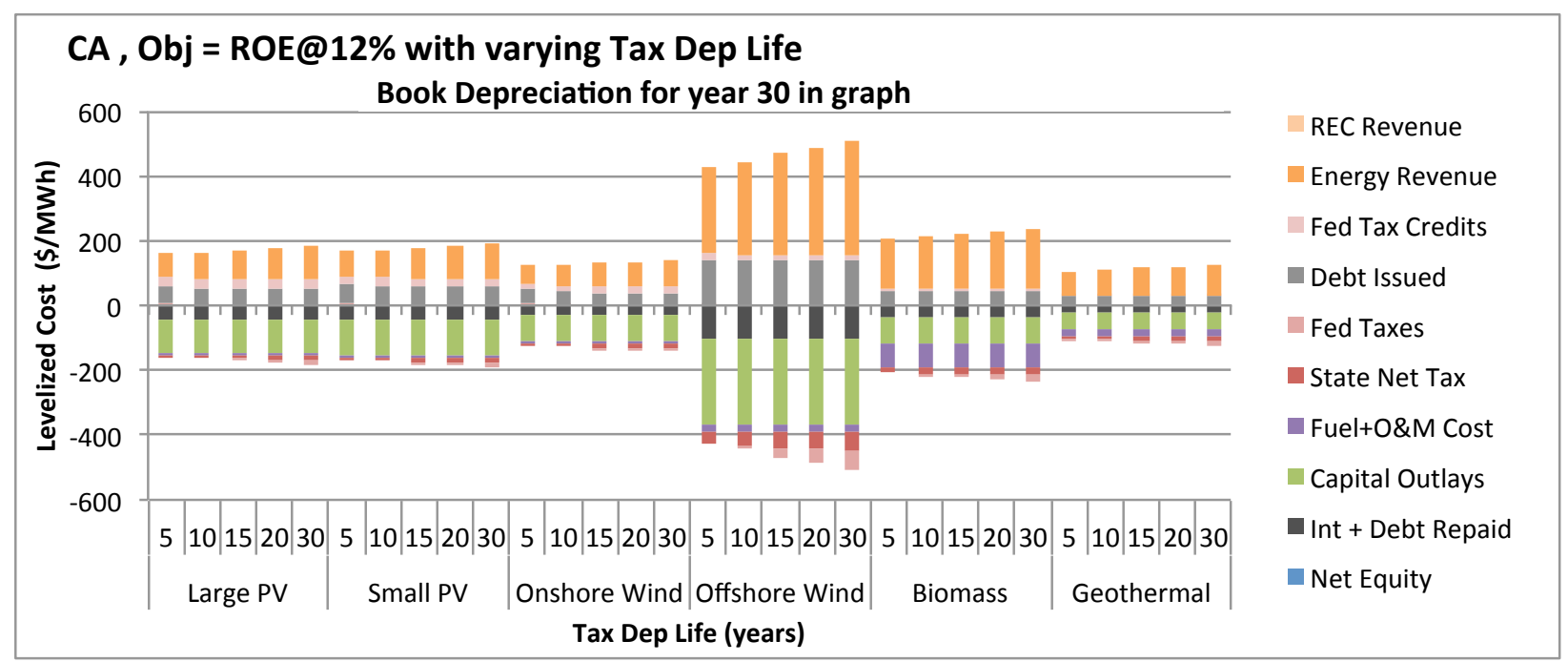

Figure 35. Tax depreciation effects on levelized costs for eight technologies in California.

Afterward, the user can put the original tax depreciation lives into TechnologyInputs!B10:I10 using the reference values in row 43.

\subsection{Input Files for Tableau to Ingest New Scenarios}

There are three worksheets in PFMT for passing information to Tableau: SensitivityAnalysis, LEP_Dashboard, and NetCashFlow_Dashboard. These collect the results from the first two cases from StoredOutputs and put them into formats useful for Tableau. The worksheets are created by running 
MultiCase running two cases, one at the Min value and one at the Max value. The data from these worksheets should be copied into the workbook SensitivityAnalysis_Dashboard.xlsx.

In addition, there is a separate workbook called TableauData.xlsx that creates tables of the Input data for Tableau. This file includes information from the TechnologyInputs, StateIncent, and StateInputs worksheets in the PFMT model and creates two worksheets (TableauStateInputs and TableauInputsFormulas) that can be copied into workbooks for the pre-computed Tableau model described in the next two sections.

\subsection{TABLEAU VISUALIZATION OF EXISTING SCENARIOS WITHIN LEP AND NET CASHFLOW DASHBOARDS}

The tableau workbook "Precomputed_Dashboards_Vxx.twbx" is the latest version which has been deployed to the Tableau server as well. This workbook can be accessed using either the Tableau desktop or Tableau server, and since the scenarios are precomputed, they need not connect to an R-server.

\subsubsection{Input settings for existing scenarios within PPA and NetCashFlow Dashboards}

PPA Map dashboard: This dashboard (Figure 36) provides the location for key inputs to be set such as the Technology; Fed Income tax rate (0 or 35\%); ITC for solar $(0,10,20$ or 30\%); PTC for Wind (0 or 23 \$/MWh); PPA Flag (with or without REC); and key output results. Figure 13 shows the inputs pane of the dashboard. The outputs include the Levelized Energy price of the selected state on the map of the United States. The map shows the state-by-state values for different key inputs, and the other widget shows the net cash flow and calculated-versus-system prices.

NetCashFlow dashboard: This dashboard (Figure 37) provides the location for key inputs to be set such as the Technology; Fed Income tax rate $(0$ or $35 \%)$; ITC for solar $(0,10$, or $30 \%)$; PTC $(0,12$, or $23 \$ / \mathrm{MWh}$ ); and key output results. The outputs include net cash flows as stacked bar charts. 


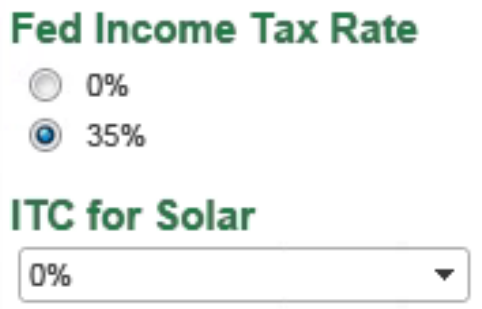

PTC (\$/MWh) for Wind
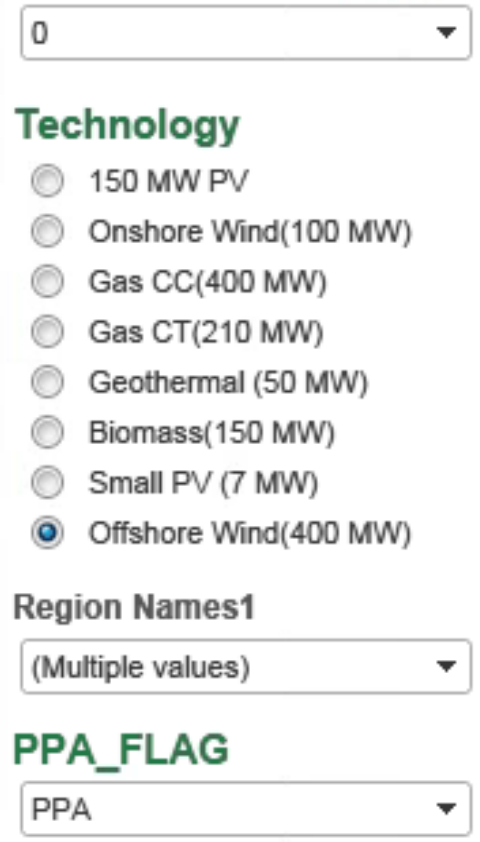

Figure 36. PPA Map dashboard inputs.
ITC

(C) $0 \%$

Geothermal

Solar

PTC(\$/MWh)

(C) 0

23

12 for Biomass

Fed Income Tax Rate

$0 \%$

(-) $35 \%$

\section{Technology}

150 MW PV

Onshore Wind(100 M...

(1) Gas CC(400 MW)

Gas CT(210 MW)

(1) Geothermal (50 MW)

Biomass(150 MW)

(1) Small PV (7 MW)

(c) Offshore Wind(400 M...

Region Names1
(All)

Figure 37. NetCashFlow dashboard inputs.

\subsubsection{Output views of existing scenarios}

The analyst can interactively visualize the results based on the input selection on the following pre-computed dashboard sheets.

LEP Map dashboard: Figure 38 below shows the output dashboard view along with the input pane. The outputs include the Levelized Energy price of the selected state on the map of the United States. The map shows the LEP prices color coded with shades of blue, and the other widget shows the net cash flows colored with an ordinal color scale. The pre-computed scenarios were computed with some fixed inputs parameters to keep the number of scenarios limited. For example, the ROE was fixed to 12\%; LEP life to 20; $50 \%$ Debt; and the interest rate was fixed to $6 \%$. 


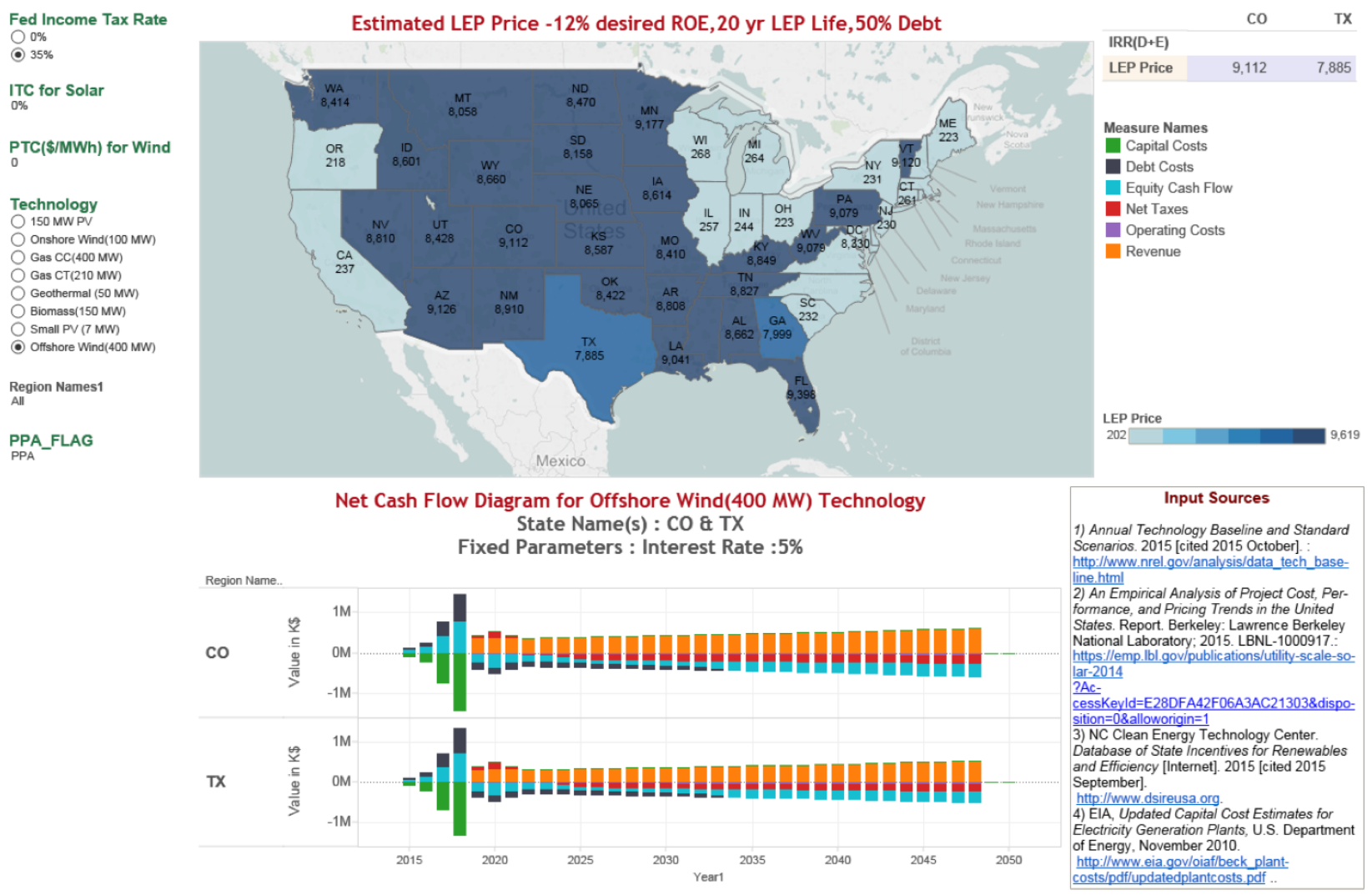

Figure 38. PPA Map dashboard displaying the LEP prices for Offshore Wind Technology.

NetCashFlow dashboard: Figure 39 below shows the output dashboard view along with the input pane. The outputs show the net cash flows colored with an ordinal color scale. The pre-computed scenarios were computed with some fixed inputs parameters to keep the number of scenarios limited. For example, the ROE was fixed to $12 \%$, LEP life to $20,50 \%$ Debt, and the interest rate was fixed to $6 \%$. 


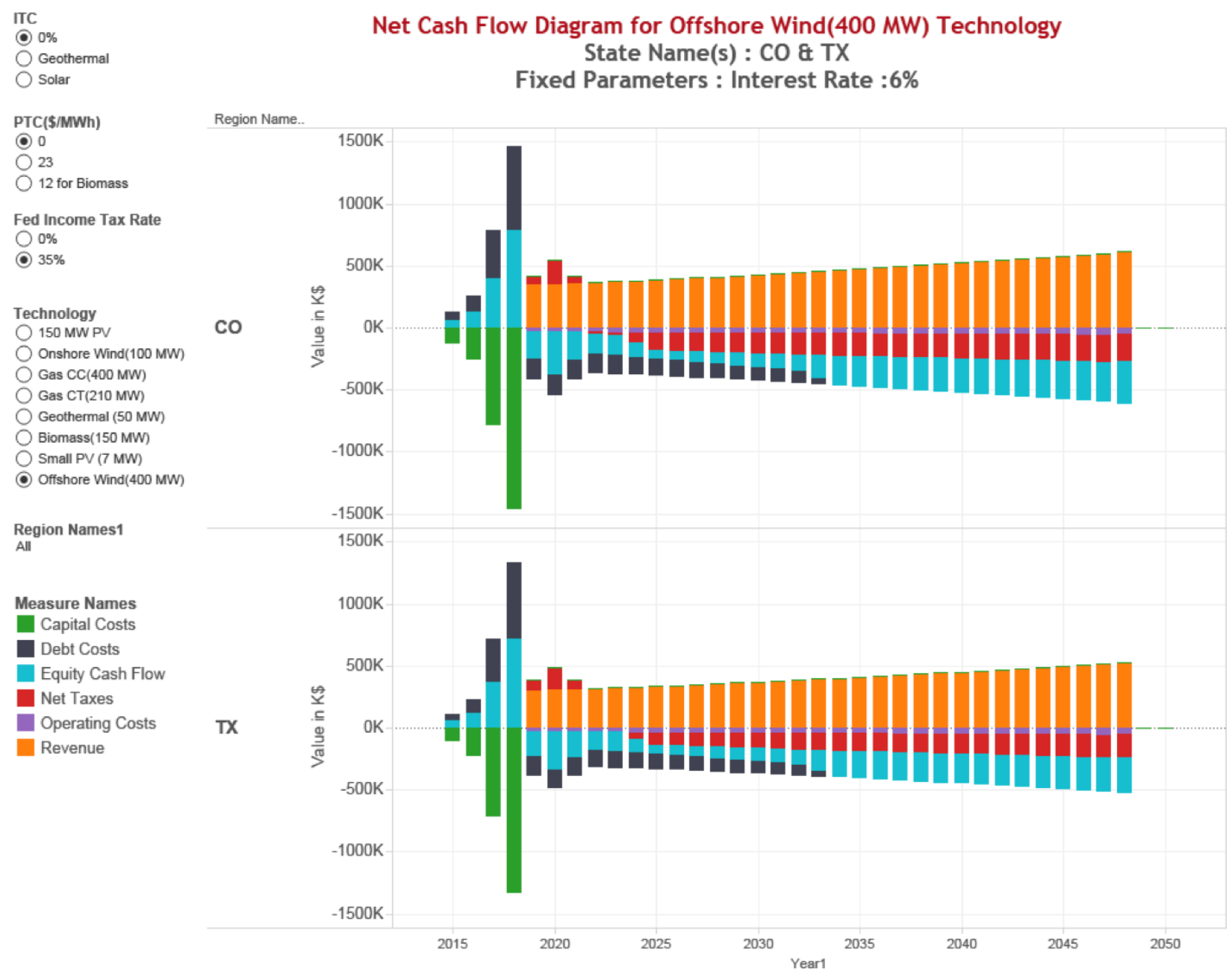

Figure 39. Net Cash Flow dashboard for Offshore Wind Technology.

\subsection{Tableau Visualization of New Scenarios within Sensitivity Analysis Dashboards}

Once new columns of data for new scenarios are available within a specific worksheet of the Excel file (SensitivityAnalysis_Dashboard.xlsx), we first need to follow the following steps to import the new data into the Tableau workbook file.

1. Select the Tableau worksheet that you need to update with new scenario data. Right click on the highlighted data source in the top left data pane. Select the option Edit Data Source and browse through your computer to get to the location of the Excel file SensitivityAnalysis_Dashboard.xlsx.

2. Select the appropriate sheet of this workbook and extract the data into the Tableau. Note that the import of the data with creation of a new extract takes approximately two minutes.

3. Once the new extract is created, go back to the original Tableau sheet. In the dimensions and measures pane, you will find new values/new scenario data attributes. If the column name is the same as the existing one, but has only updated data, then no new attributes show up, in which case there may be no additional steps to perform.

4. Once new measures are available to visualize, we can create a new calculated field to consolidate the new measures of all the technologies based on the Technology Selection parameter value and 
add the new measure to the visualization window. If the measures are not parameter dependent, then they can be added directly on the visualization window.

Examples of newly calculated fields based on the "Technology Selection" parameter value are given below:

Measure Name: LEP Energy Price

CASE [Technology Selection 1] WHEN 0 THEN [Large PV LEP Energy Price]

WHEN 1 THEN [Onshore Wind LEP Energy Price]

WHEN 2 THEN [Gas CC LEP Energy Price]

WHEN 3 THEN [Gas CT LEP Energy Price]

WHEN 4 THEN [Geothermal LEP Energy Price]

WHEN 5 THEN [Biomass LEP Energy Price]

WHEN 6 THEN [Small PV LEP Energy Price]

WHEN 7 THEN [Offshore Wind LEP Energy Price]

END

Measure Name: LEP_System

[LEP Energy Price] - [System Price]

Measure Name: LEP_System_Color

IF [LEP_System] $<=-50$ THEN "<=-50"

ELSEIF [LEP_System] $>-50$ AND [LEP_System] $<=-10$ THEN ">-50 and <=-10"

ELSEIF [LEP_System] $>-10$ AND [LEP_System] $<=10$ THEN " $>-10$ and $<=10 "$

ELSEIF [LEP_System] $>10$ AND [LEP_System] $<=50$ THEN "> 10 and $<=50 "$

ELSEIF [LEP_System] $>50$ AND [LEP_System] $<=90$ THEN " $>50$ and $<=90 "$

ELSEIF [LEP_System] $>90$ AND [LEP_System] $<=100$ THEN ">90 and $<=1000 "$

ELSE "NA"

END

For instance, if LEP_System_Color is dropped on the color pane of a U.S. tile map, then the LEP Price-System Price values are displayed on a tile map using an ordinal scale of colors.

\subsection{Tableau Visualization of Existing Scenarios within Sensitivity Analysis Dashboards}

The Tableau workbook PrecomputedDashboard_Vxx.twbx also provides Sensitivity Analysis dashboards.

This workbook connects to multiple data sources listed below:

1. ITC (SensitivityAnalysis_Dashboard.xlsx)

2. PTC (SensitivityAnalysis_Dashboard.xlsx)

3. Tax Dep Life (SensitivityAnalysis_Dashboard.xlsx)

4. Reference Cases (SensitivityAnalysis_Dashboard.xlsx)

5. RefCases_Noincentives(SensitivityAnalysis_Dashboard.xlsx)

To use the pre-computed sensitivity analysis dashboards, refer to section Multi-Case SENSITIVITY Analysis VISUALIZATION. 


\subsection{Tableau Visualization of New Scenarios within LEP Dashboard and Net Cash Flow Dashboard for Precomputed Scenario Workbook}

The Tableau workbook PrecomputedDashboard_Vxx.twbx provides both Sensitivity Analysis dashboards and pre-computed PPA Map dashboard and the NetCashFlow dashboard.

This workbook connects to multiple data sources listed below:

1. Sheet1 (PPA_Dashboard_Vxx.xlsx),

2. Sheet1(NetCashFlow_Dashboard.xlsx).

\subsubsection{PPA Map Dashboard}

Once new columns of data for new scenarios are available within a specific worksheet of the Excel file (PPA_Dashboard_Vxx.xlsx), we first need to follow the steps below to import the new data into the Tableau workbook file.

1. Select the Tableau worksheet (Estimated PPA Output Map) that you need to update with new scenario data. Right click on the highlighted data source in the top left data pane. Select the option Edit Data Source and browse through your computer to get to the location of the Excel file PPA_Dashboard_Vxx.xlsx.

2. Select the appropriate sheet of this workbook (Sheet1) and extract the data into the Tableau. Note that the import of the data with creation of a new extract takes approximately two minutes.

3. Once the new extract is created, go back to the original Tableau sheet. In the dimensions and measures pane, you will find new values/new scenario data attributes. If the column name is the same as the existing one but has only updated data, then no new attributes show up, in which case there may be no additional steps to perform.

4. Once new measures are available to visualize, we can create a new calculated field to consolidate the new measures and add the new measure to the visualization window. If the measures are not parameter dependent, then they can be added directly on the visualization window.

An example of a modified measure to accommodate new interest rate scenario data is given below:

Original Measure : PPA_GasCC

IF ([Fed Income Tax Rate]=0) THEN [LEP Gas CC ROE12 INT6 FedIT0 ITC0 PTC0]

ELSEIF ([Fed Income Tax Rate]=35) then [LEP Gas CC ROE12 INT6 FedIT35 ITC0 PTC0]

END WHEN 7 THEN [Offshore Wind LEP Energy Price]

END

Modified Measure : LEP_System

$\mathrm{IF}([$ Interest Rate $]=6)$

IF ([Fed Income Tax Rate]=0) THEN [LEP Gas CC ROE12 INT6 FedIT0 ITC0 PTC0]

ELSEIF ([Fed Income Tax Rate]=35) then [LEP Gas CC ROE12 INT6 FedIT35 ITC0 PTC0]

END WHEN 7 THEN [Offshore Wind LEP Energy Price] 
$\operatorname{ELSIF}([$ Interest Rate $]=7)$

IF ([Fed Income Tax Rate]=0) THEN [LEP Gas CC ROE12 INT7 FedIT0 ITC0 PTC0]

ELSEIF ([Fed Income Tax Rate]=35) then [LEP Gas CC ROE12 INT7 FedIT35 ITC0 PTC0]

END WHEN 7 THEN [Offshore Wind LEP Energy Price]

END

\subsubsection{Net Cash Flow Dashboard}

Once new columns of data for new scenarios are available within a specific worksheet of the Excel file (NetCashFlow_Dashboard.xlsx), we first need to follow the below steps to import the new data into the Tableau workbook file.

1. Select the Tableau worksheet (Estimated PPA Output Map) that you need to update with new scenario data. Right click on the highlighted data source in the top left data pane. Select the option Edit Data Source and browse through your computer to find the location of the Excel file NetCashFlow_Dashboard.xlsx file.

2. Select the appropriate sheet of this workbook (Sheet1) and extract the data into the Tableau. Note that the import of the data with creation of a new extract takes approximately two minutes.

3. Once the new extract is created, return to the original Tableau sheet. In the dimensions and measures pane, you will find new values/new scenario data attributes. If the column name is the same as the existing one but has only updated data, then no new attributes show up, in which case there may be no additional steps to perform.

4. Once new measures are available to visualize, we can create a new calculated field to consolidate the new scenarios and add the new measure to the visualization window. If the measures are not parameter dependent, then they can be added directly on the visualization window.

Examples of a modified measure to accommodate new allowed ROE scenario data are given below:

Original Measure : CC_GasCC

IF [Allowed ROE]=8 THEN

IF ([Fed Income Tax Rate]=0) THEN [CC GasCC ROE8 Int5 FedIT0 ITC0 PTC0]

ELSEIF ([Fed Income Tax Rate]=35) THEN [CC GasCC ROE8 Int5 FedIT35 ITC0 PTC0]

END

ELSE

IF ([Fed Income Tax Rate]=0) THEN [CC GasCC ROE12 Int5 FedIT0 ITC0 PTC0]

ELSE [CC GasCC ROE12 Int5 FedIT35 ITC0 PTC0]

END

END

Modifed Measure : : CC_GasCC

IF [Allowed ROE] $=8$ THEN

IF ([Fed Income Tax Rate]=0) THEN [CC GasCC ROE8 Int5 FedIT0 ITC0 PTC0]

ELSEIF ([Fed Income Tax Rate]=35) THEN [CC GasCC ROE8 Int5 FedIT35 ITC0 PTC0]

END 
ELSIF [Allowed ROE] $=12$ THEN

IF ([Fed Income Tax Rate]=0) THEN [CC GasCC ROE12 Int5 FedIT0 ITC0 PTC0]

ELSE [CC GasCC ROE12 Int5 FedIT35 ITC0 PTC0]

END

ELSE

IF ([Fed Income Tax Rate]=0) THEN [CC GasCC ROE10 Int5 FedIT0 ITC0 PTC0]

ELSE [CC GasCC ROE10 Int5 FedIT35 ITC0 PTC0]

END

END 


\section{REFERENCES}

Blair N, Cory K, Hand M, Parkhill L, Speer B, Stehly T, Feldman D, Lantz E, Augustine C, Turchi C, et al. Annual Technology Baseline and Standard Scenarios. 2015 [cited 2015 October]. Available from: http://www.nrel.gov/analysis/data_tech_baseline.html.

Barbose, Galen and Naïm Darghouth, Tracking the Sun VIII: The Installed Price of Residential and NonResidential Photovoltaic Systems in the United States, LBNL-188238, Lawrence Berkeley National Laboratory, August 2015. Available from: https://emp.lbl.gov/sites/all/files/lbnl-188238_1.pdf .

Bolinger M, Seel J. Utility-Scale Solar 2014: An Empirical Analysis of Project Cost, Performance, and Pricing Trends in the United States. Report LBNL-1000917. Lawrence Berkeley National Laboratory; 2015. Available from: https://emp.lbl.gov/publications/utility-scale-solar-2014 .

CRA 2013, Working Draft of MRN-NEEM Modeling Assumptions and Data Sources for EIPC Capacity Expansion Modeling, Charles Rivers Associates for the Eastern Interconnection Planning Collaborative, December 2010.

http://nebula.wsimg.com/2b7b1e7ee96323d67024eae668e9e2c8?AccessKeyId=E28DFA42F06A3AC213 $\underline{03 \& \text { disposition }=0 \& \text { alloworigin }=1}$

EIA, Updated Capital Cost Estimates for Electricity Generation Plants, U.S. Department of Energy, November 2010. Available from: http://www.eia.gov/oiaf/beck_plantcosts/pdf/updatedplantcosts.pdf

Energy Information Administration. Annual Energy Outlook 2015. DOE/EIA-0383(2015), U.S. Department of Energy, 2015. Available from: http://www.eia.gov/forecasts/aeo/assumptions/

Energy Information Administration. Assumptions to the Annual Energy Outlook 2015. DOE/EIA0554(2015), U.S. Department of Energy, 2015. Available from: http://www.eia.gov/forecasts/aeo/

Energy Information Administration 2015, Levelized Cost and Levelized Avoided Cost of New Generation Resources in the Annual Energy Outlook 2015, DOE/EIA- (2015), U.S. Department of Energy, June 2015. Available from http://www.eia.gov/forecasts/aeo/electricity_generation.cfm

EIA 2015, Electricity: Detailed State Data, [Internet], Release Date: October 21, 2015, Accessed October 22, 2015. Available from: http://www.eia.gov/electricity/data/state/ .

EIA 2016, Carbon Dioxide Emissions Coefficients [Internet], Release Date: February 2, 2016, Accessed March 23, 2016. Available from http://www.eia.gov/environment/emissions/co2_vol_mass.cfm .

Federal Energy Regulatory Commission, Form 714 - Annual Electric Balancing Authority Area and Planning Area Report, 2015. http://www.ferc.gov/docs-filing/forms/form-714/overview.asp

Hadley, Stanton W., Lawrence J. Hill, and Robert D. Perlack, Report on the Study of Tax and Rate Treatment of Renewable Energy Projects, ORNL-6772, Martin Marietta Energy Systems, Inc., Oak Ridge National Laboratory, December 1993. http://www.ornl.gov/ webworks/cpr/v823/rpt/68456.pdf

Internal Revenue Service, 2015, Publication 946: How To Depreciate Property, Accessed March 23, 2016, Available from: https://www.irs.gov/pub/irs-pdf/p946.pdf . 
Lincoln Institute of Land Policy and Minnesota Taxpayers Association, 50-State Property Tax Comparison Study, April 2011. Available from: http://www.lincolninst.edu/subcenters/significantfeatures-property-tax/upload/sources/ContentPages/documents/MTAdoc_NewCover.pdf .

NC Clean Energy Technology Center, 2015, Database of State Incentives for Renewables and Efficiency [Internet], cited September 2015. Available from: http://www.dsireusa.org.

NREL, TruPower 2011 (Wind capacity and generation data updated for AL and $\mathrm{HI}$ at $>30 \% \mathrm{CF}$ and $80 \mathrm{~m}$ ) Release Date: April 13, 2011. Accessed October 22, 2015. Available from:

http://apps2.eere.energy.gov/wind/windexchange/pdfs/wind_maps/wind_potential_80m_30percent.pdf .

NREL 2015, Annual Technology Baseline, Release Date: July 16, 2015. Accessed June 23, 2016.

Available from: http://www.nrel.gov/analysis/data_tech_baseline.html

Tax-Rates.org, "Sales Tax Rates by State," [Internet]. Cited October 2015. Available from:

http://www.tax-rates.org/taxtables/sales-tax-by-state .

Tax-Rates.org, "Average Corporate Income Tax Rates by State," [Internet] Cited October 2015. Available from: http://www.tax-rates.org/taxtables/corporate-income-tax-by-state . 